\title{
VANESSA NOGUEIRA
}

Uso ou omissão de preposição e artigo em orações relativas de espanhol produzidas por estudantes brasileiros

Dissertação apresentada ao Programa de Pós-Graduação em Língua Espanhola e Literaturas Espanhola e Hispano-Americana do Departamento de Letras Modernas da Faculdade de Filosofia, Letras e Ciências Humanas da Universidade de São Paulo para a obtenção do título de Mestre em Letras.

Orientadora: Profa. Dra. Mirta María Groppi A. de Varalla

São Paulo

2014 


\section{VANESSA NOGUEIRA}

Uso ou omissão de preposição e artigo em orações relativas de espanhol produzidas por estudantes brasileiros

Dissertação apresentada ao Programa de Pós-Graduação em Língua Espanhola e Literaturas Espanhola e Hispano-Americana do Departamento de Letras Modernas da Faculdade de Filosofia, Letras e Ciências Humanas da Universidade de São Paulo para a obtenção do título de Mestre em Letras.

Orientadora: Profa. Dra. Mirta María Groppi A. de Varalla

São Paulo

2014

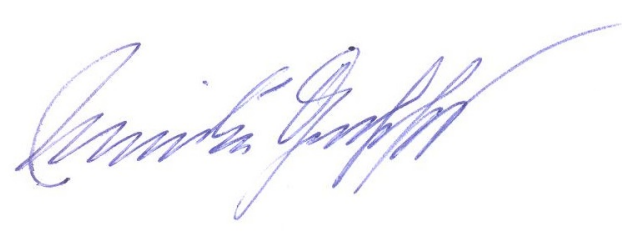


Autorizo a reprodução e divulgação total ou parcial deste trabalho, por qualquer meio convencional ou eletrônico, para fins de estudo e pesquisa, desde que citada a fonte.

Catalogação da Publicação

Serviço de Biblioteca e Documentação

Faculdade de Filosofia, Letras e Ciências Humanas da Universidade de São Paulo

Nogueira, Vanessa

Uso ou omissão de preposição e artigo em orações relativas de espanhol produzidas por estudantes brasileiros / Vanessa Nogueira; orientadora: Mirta María Groppi Asplanato de Varalla - São Paulo, 2014

$144 f$.

Dissertação (Mestrado) - Universidade de São Paulo, 2014.

1. Orações relativas. 2. Cortadoras. 3. Preposição. 4. Artigo. 5. Espanhol. 
Nome: NOGUEIRA, Vanessa

Título: Uso ou omissão de preposição e artigo em orações relativas de espanhol produzidas por estudantes brasileiros

Dissertação apresentada ao Programa de PósGraduação em Língua Espanhola e Literaturas Espanhola e Hispano-Americana do Departamento de Letras Modernas da Faculdade de Filosofia, Letras e Ciências Humanas da Universidade de São Paulo para a obtenção do título de Mestre em Letras.

Aprovado em:

Banca Examinadora

Prof. Dr.: Instituição:

Julgamento: Assinatura:

Prof. Dr.: Instituição: Julgamento: Assinatura:

Prof. Dr.: Instituição: Julgamento: Assinatura: 


\section{Dedicatória}

Aos meus pais, com amor, carinho e gratidão pelo apoio e força durante todos

estes anos.

Ao meu esposo Gênio, pela compreensão, ajuda e incentivo ao longo do período de elaboração deste trabalho.

À minha querida irmã, que mesmo sem estar por perto, sempre esteve comigo me fortalecendo.

E à Chocolate, cachorrinha incrível com nome de doce que me fez compreender o amplo significado do verbo "doar-se". 


\section{Agradecimentos}

Agradeço à Profa. Dra. Mirta María Groppi Alplanato de Varalla, não somente pela orientação, apoio e paciência durante a Pós-Graduação, mas também pelo incentivo durante a graduação e por acreditar em minhas ideias.

À Profa. Dra. Neide Therezinha Maia González, pelo apoio, carinho e força durante estes anos da Pós-Graduação.

Aos meus familiares e amigos, pela compreensão da distância durante o tempo deste trabalho.

Aos meus pais, pela força e paciência durante toda a vida. Em especial à minha mãe, pelo exemplo de otimismo, força e generosidade.

Por fim, agradeço ao meu marido, Gênio, pela compreensão, ajuda, amor e, principalmente, por acreditar em mim. 
"El día que me quieras

endulzará sus cuerdas

el pájaro cantor.

Florecerá la vida

no existirá el dolor."

"El día que me quieras" - Carlos Gardel 


\section{Resumo}

NOGUEIRA, V. Uso ou omissão de preposição e artigo em orações relativas de espanhol produzidas por estudantes brasileiros. 2014. (144f). Dissertação (Mestrado) - Faculdade de Filosofia, Letras e Ciências Humanas, Universidade de São Paulo, 2014.

O objetivo desta dissertação é comparar o uso ou a omissão de preposições e artigos nas orações relativas de estudantes brasileiros de ELE e nativos de E. O estudo buscou verificar se os estudantes brasileiros de ELE utilizam o relativo acompanhado de preposição e artigo, quando o usam e como o fazem; quais contextos favorecem a elipse de "preposição + artigo"; se o comportamento sintático entre os estudantes brasileiros e os nativos se assemelha e quais as possibilidades para essas semelhanças / diferenças. Para tanto, analisamos um corpus recolhido de testes escritos de reformulação de orações de três grupos de estudantes brasileiros adultos de ELE e o comparamos às produções de reformulações de um grupo de nativos de $\mathrm{E}$ argentinos. De acordo com nossas hipóteses iniciais e bibliografia consultada, as orações cortadoras seriam as mais produzidas pelos estudantes, mas de acordo com nossos dados, essa não foi a opção mais usada, e sim a opção sem o artigo com preposição. Pensamos que isso se deve ao caráter mais formal (escrito) dos testes. Concluímos que os brasileiros, em sua língua nativa, não usariam tal estrutura, mas quando têm que lidar com o E, preferem cortar o artigo em vez de produzir uma estrutura que seja mais comum em PB - como a cortadora. Em contrapartida, os nativos usaram com mais frequência as orações padrão, que quase não apareceram nos resultados dos estudantes brasileiros. Ou seja, o comportamento sintático dos estudantes brasileiros e dos nativos foram evidentemente diferentes. Os estudantes brasileiros nem sempre preferiram o uso de relativas com "quien" para antecedente [+animado], como predizem as gramáticas. Aliás, o uso das duas orações padrão ("prep. + quien" e "prep.+ art. + que) foi bastante equilibrado. Os nativos de $\mathrm{E}$, para o mesmo tipo de antecedente, usaram a oração padrão com o relativo "que" com maior frequência. Quando a oração relativa apresentou caráter causal, os informantes brasileiros e nativos foram levados a expressar essa relação causal e evitaram a oração relativa.

Palavras-chave: orações relativas, cortadoras, preposição, artigo, espanhol. 


\section{Abstract}

NOGUEIRA, V. Uso ou omissão de preposição e artigo em orações relativas de espanhol produzidas por estudantes brasileiros. 2014. (144f). Dissertação (Mestrado) - Faculdade de Filosofia, Letras e Ciências Humanas, Universidade de São Paulo, 2014.

The objective of this dissertation is to compare the use or omission of prepositions in relative clauses and articles of Brazilian students of ELE and native $E$ speakers. The study aimed at verifing whether the Brazilian students use prepositions, accompanied by the relative pronoun and articles, when they use and how they do that; contexts which favor the ellipse "preposition + article"; if the syntactic behavior among Brazilian students matches the native speakers' and the possibilities for these similarities / differences. To this end, we collected a corpus reformulation's sentences of written tests of three groups of Brazilian adult students of ELE and compared to the production of reformulations of a group of Argentinian E. native speakers. According to our initial hypotheses and consulted literature, students produce more often pp-chopping sentences, but according to our data, this was not the preferred option, but the one without article and with preposition. We think this is due to the more formal nature of the (written) tests. We concluded that Brazilian students in their native language would not use such a structure, but when they have to deal with $E$, they prefer to cut the article instead of producing a structure that is more common in PB - like the pp-chopping. In contrast, the native speakers used standard sentences more often, which hardly ever appeared in the results of Brazilian students. That is, the syntactic behavior of Brazilian students and native speakers were evidently different. Brazilian students do not always preferred the use of relative pronoun using "quien" for the antecedent [+ animate], as grammatically expected. In fact, the use of two standard sentences ("prep. + quien" and "prep. + art. + que") was fairly balanced. The native speakers of $E$, for the same type antecedent, used the standard sentence with the relative "que" with more frequency. When the relative clause introduced causal character, Brazilians and native speaker informants were led to express this causal relationship and avoided the relative clause.

Keywords: relative clauses, pp-chopping, preposition, article, spanish. 


\section{Resumen}

NOGUEIRA, V. Uso ou omissão de preposição e artigo em orações relativas de espanhol produzidas por estudantes brasileiros. 2014. (144f). Dissertação (Mestrado) - Faculdade de Filosofia, Letras e Ciências Humanas, Universidade de São Paulo, 2014.

El objetivo de este trabajo consiste en comparar el uso u omisión de preposiciones y artículos en las cláusulas relativas de estudiantes brasileños de ELE y nativos de E. El estudio busca comprobar si los estudiantes brasileños utilizan el relativo acompañado de preposición y artículo, cuándo lo usan y cómo lo hacen; cuáles contextos favorecen la elipsis de "preposición + artículo"; si el comportamiento sintáctico entre los estudiantes brasileños y los nativos se asemeja y cuáles son las posibilidades para esas semejanzas / diferencias. Para esto, analizamos un corpus recogido de testes escritos de reformulaciones de cláusulas de tres grupos de estudiantes brasileños adultos de ELE y las comparamos a las producciones de reformulaciones de un grupo de nativos de $\mathrm{E}$, argentinos. De acuerdo con nuestras primeras hipótesis y bibliografía consultada, las oraciones cortadoras serían las que más producirían los estudiantes, pero de acuerdo con nuestros datos, esa no fue la opción más usada, pero sí la opción sin el artículo con preposición. Pensamos que esto se debe al carácter más formal (escrito) de los testes. Concluimos que los brasileños, en su lengua nativa, no usarían esa estructura, pero cuando tienen que lidiar con el E, prefieren cortar el artículo al revés de producir una estructura más común en PB - como la cortadora. En contrapartida, los nativos usaron con más frecuencia las oraciones estándar, que casi no aparecen en los resultados de los estudiantes brasileños. Es decir, el comportamiento sintáctico de los estudiantes brasileños y los nativos fueron evidentemente diferentes. Los estudiantes brasileños no siempre prefirieron el uso de las relativas con "quien" para el antecedente [+animado], como dicen las gramáticas. Además, el uso de las dos cláusulas estándar ("prep. + quien" y "prep. + art. + que") fue bastante equilibrado. Los nativos de E, para el mismo tipo de antecedente, usaron la oración estándar con el relativo "que" con mayor frecuencia. Cuando la oración relativa presenta un carácter causal, los informantes brasileños y nativos son llevados a expresar esa relación causal y evitan la oración relativa.

Palabras clave: oraciones relativas, cortadoras, preposición, artículo, español. 


\section{Lista de Gráficos}

Gráfico 1 - Reformulações dos estudantes brasileiros de ELE para a oração B......................................................................... 64

Gráfico 2 - Reformulações dos Hispanofalantes para oração B...................... 67

Gráfico 3 - Reformulações dos estudantes brasileiros de ELE para a oração C....................................................................... 72

Gráfico 4 - Reformulações dos Hispanofalantes para oração C....................... 75

Gráfico 5 - Reformulações dos estudantes brasileiros de ELE para a oração D............................................................................ 78

Gráfico 6 - Reformulações dos Hispanofalantes para a oração D.................... 80

Gráfico 7 - Reformulações dos estudantes brasileiros de ELE para a

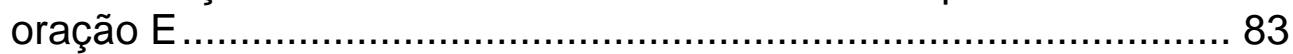

Gráfico 8 - Reformulações dos Hispanofalantes para a oração E.................... 85

Gráfico 9 - Reformulações dos estudantes brasileiros de ELE para a

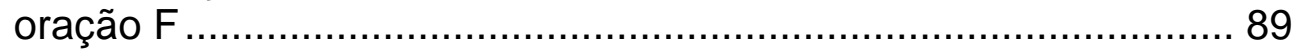

Gráfico 10 - Reformulações dos Hispanofalantes para a oração F .................... 91

Gráfico 11 - Reformulações dos estudantes brasileiros de ELE para a

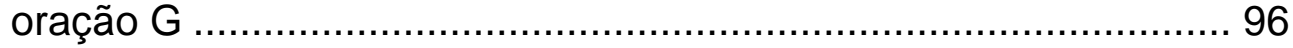

Gráfico 12 - Reformulações dos Hispanofalantes para a oração G .................. 99

Gráfico 13 - Reformulações dos estudantes brasileiros de ELE para a oração H.................................................................... 102

Gráfico 14 - Reformulações dos Hispanofalantes para a oração H................... 104

Gráfico 15 - Reformulações dos estudantes brasileiros de ELE para a

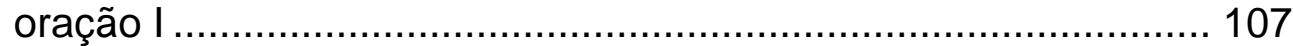

Gráfico 16 - Reformulações dos Hispanofalantes para a oração I .................... 109

Gráfico 17 - Reformulações dos estudantes brasileiros de ELE para a oração J ............................................................................. 112

Gráfico 18 - Reformulações dos Hispanofalantes para a oração J ................... 114 


\section{Sumário}

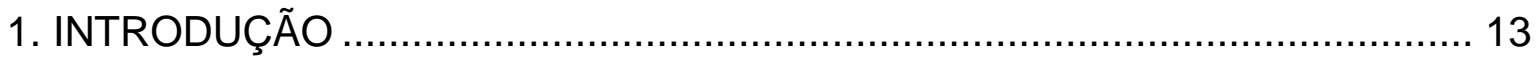

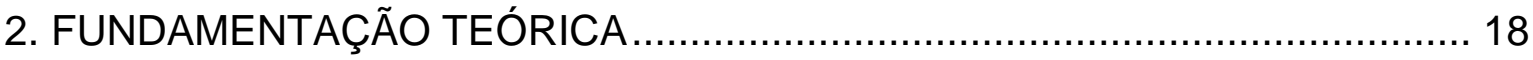

2.1. AS ORAÇÕES RELATIVAS NA GRAMÁTICA DO ESPANHOL................ 18

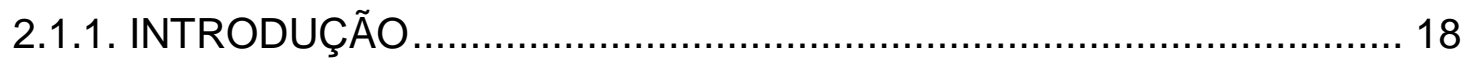

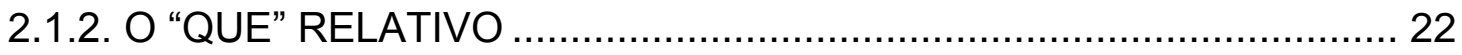

2.1.3. "QUE” RELATIVO X "QUE" COMPLETIVO .................................... 24

2.1.4. AUSÊNCIA E PRESENÇA DE ARTIGOS NAS ORAÇÕES RELATIVAS

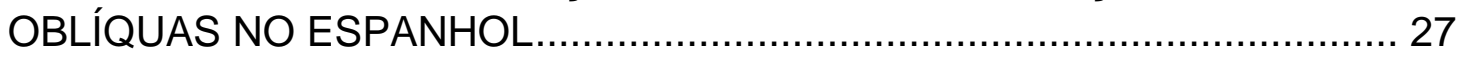

2.1.5. AUSÊNCIA E PRESENÇA DE PREPOSIÇÕES NAS ORAÇÕES RELATIVAS OBLÍQUAS NO ESPANHOL ............................................. 29

2.2. AS ORAÇÕES RELATIVAS NA GRAMÁTICA DO PORTUGUÊS

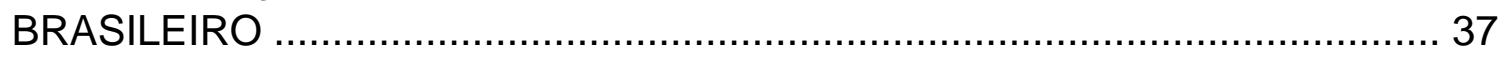

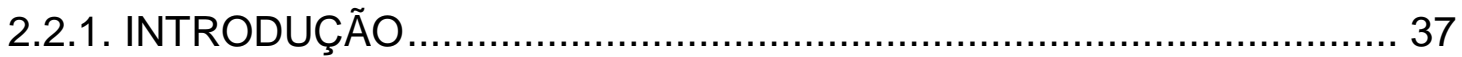

2.2.2. AS PREPOSIÇÕES NAS ORAÇÕES RELATIVAS DO PORTUGUÊS

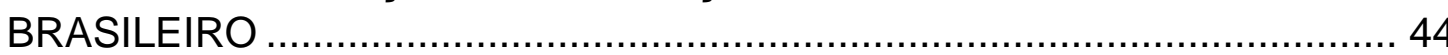

2.2.3. O ARTIGO DEFINIDO NAS ORAÇÕES RELATIVAS DO PORTUGUÊS

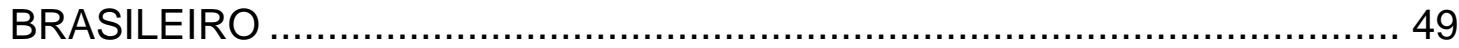

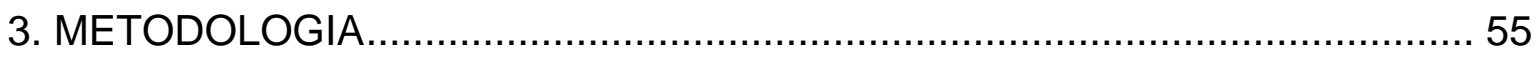

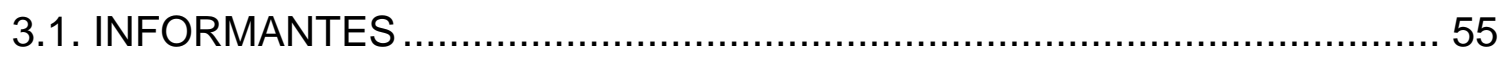

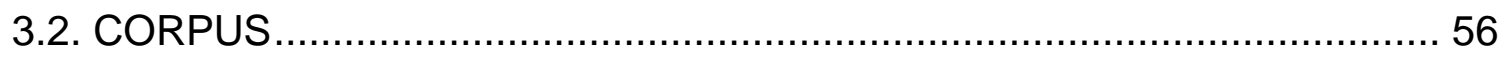

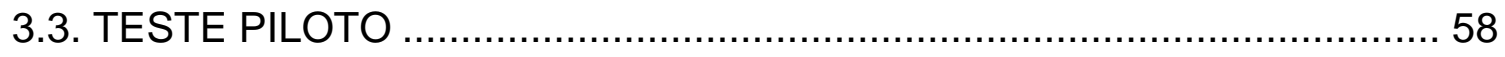

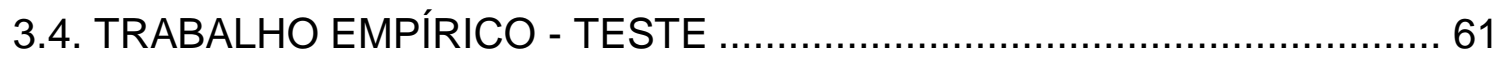

3.5. ORGANIZAÇÃO DOS DADOS PARA A ANÁLISE ................................. 62

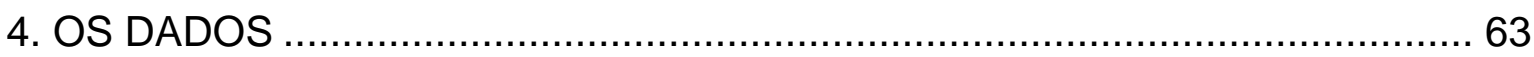

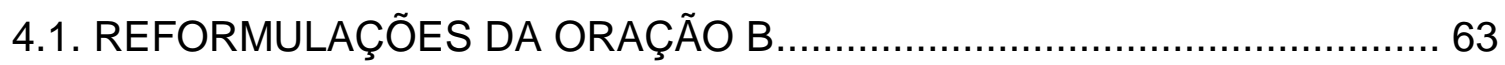

4.1.1. Gráfico das reformulações dos estudantes brasileiros de ELE ............ 63

4.1.2. Gráfico das reformulações dos Hispanofalantes ............................... 66

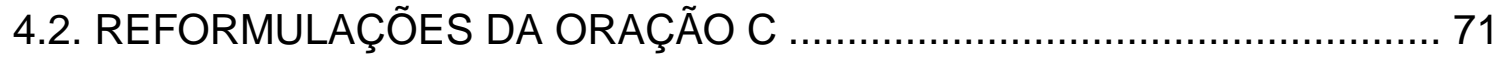

4.2.1. Gráfico das reformulações dos estudantes brasileiros de ELE ............ 71

4.2.2. Gráfico das reformulações dos Hispanofalantes .............................. 74

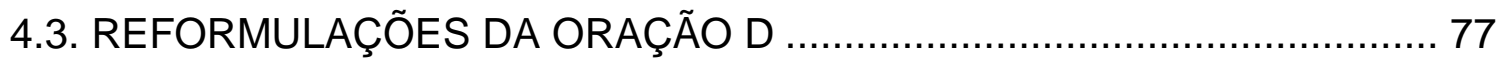


4.3.1. Gráfico das reformulações dos estudantes brasileiros de ELE ............ 77

4.3.2. Gráfico das reformulações dos Hispanofalantes ................................ 79

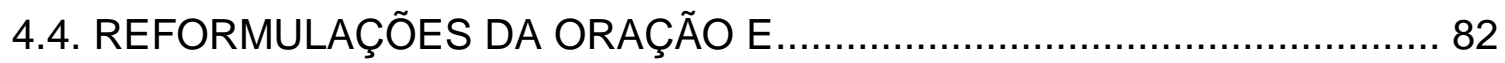

4.4.1. Gráfico das reformulações dos estudantes brasileiros de ELE ............ 82

4.4.2. Gráfico das reformulações dos Hispanofalantes ............................... 85

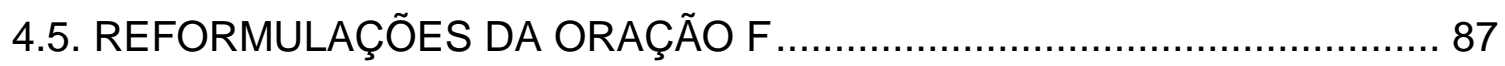

4.5.1. Gráfico das reformulações dos estudantes brasileiros de ELE ............ 88

4.5.2. Gráfico das reformulações dos Hispanofalantes ............................... 90

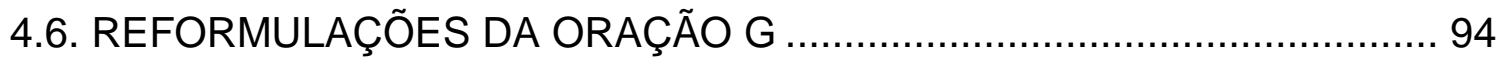

4.6.1. Gráfico das reformulações dos estudantes brasileiros de ELE ............ 95

4.6.2. Gráfico das reformulações dos Hispanofalantes ................................ 98

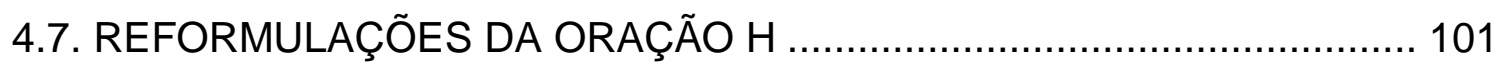

4.7.1. Gráfico das reformulações dos estudantes brasileiros de ELE.......... 101

4.7.2. Gráfico das reformulações dos Hispanofalantes ............................... 104

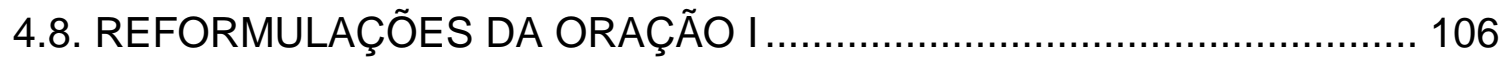

4.8.1. Gráfico das reformulações dos estudantes brasileiros de ELE.......... 106

4.8.2. Gráfico das reformulações dos Hispanofalantes .............................. 108

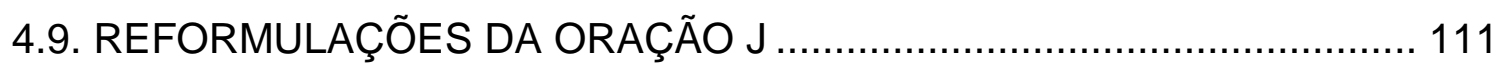

4.9.1. Gráfico das reformulações dos estudantes brasileiros de ELE .......... 111

4.9.2. Gráfico das reformulações dos Hispanofalantes .............................. 113

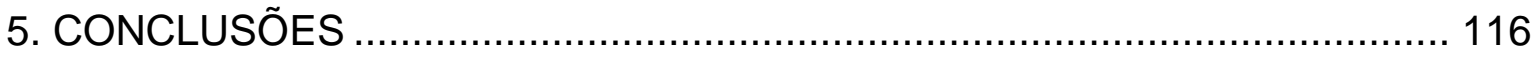

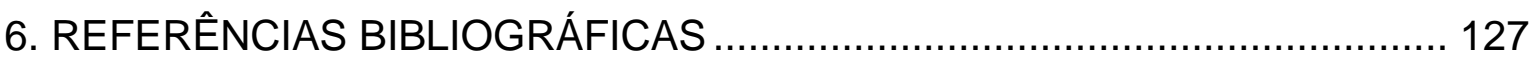

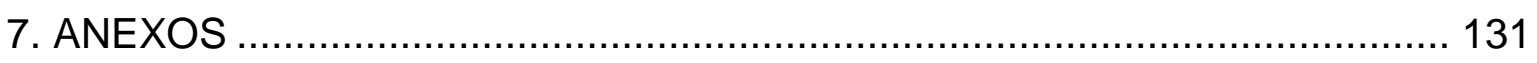

7.1. ANEXO 1 - FICHA DOS INFORMANTES BRASILEIROS ..................... 131

7.2. ANEXO 2 - FICHA DOS INFORMANTES HISPANOFALANTES............ 132

7.3. ANEXO 3 - TESTE PARA INFORMANTES BRASILEIROS E

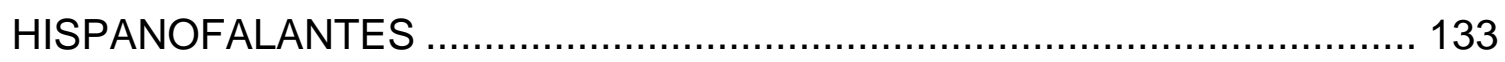

7.4. ANEXO 4 - Reformulações dos informantes .......................................... 134 
O uso ou omissão de preposição e artigo nas orações relativas de espanhol de estudantes brasileiros

\section{INTRODUÇÃO}

Neste trabalho, trataremos as orações relativas especificativas com o pronome relativo "que". Devido ao aparecimento de orações com o advérbio "donde" e o pronome relativo "quien", ambos serão mencionados ocasionalmente.

Nosso interesse pelas orações relativas com "que" começou quando, em uma de nossas aulas de curso regular em empresas cujo tema eram as orações relativas com preposição e artigo, um aluno adulto, com mais de 240 horas de exposição à língua, que havia realizado corretamente todos os exercícios escritos propostos, nos perguntou, ao final da aula, por que deveria usar aquelas orações com artigo + preposição + "que" (1a), se usando somente o relativo "que" (1b), a oração teria o mesmo sentido.

1. a. La empresa en la que trabajé estaba lejos.

b. La empresa que trabajé estaba lejos.

A partir desse momento passamos a investigar a realização de orações relativas especificativas nas produções escritas e orais de nossos alunos adultos 
com mais de 130 horas de exposição à língua. Verificamos que eles quase não usavam as orações com preposição e artigo e quando usavam uma oração relativa, empregavam, na maioria das vezes, somente o pronome relativo "que".

Embora pudessem usar as estruturas com preposição e artigo em uma atividade específica de uma prova escrita - atividade que explicitamente pedia esta estrutura no enunciado - nas produções orais, não as produziam.

Segundo Perroni (2001), os alunos de PB possuem grande dificuldade para usar as relativas com preposição. A autora afirma que Correa (1998) já havia demonstrado essa dificuldade dos alunos brasileiros de português $L 1$ com relação às relativas preposicionadas.

Em um dos nossos trabalhos finais de uma disciplina da pós-graduação ${ }^{1}$, vimos claramente exemplos de rejeição a este tipo de estrutura por estudantes adultos de Espanhol como Língua Estrangeira (ELE) ${ }^{2}$ :

2. a. Ese es el profesor que debes entregar una reseña semanalmente. b. Yo tenía un empleo que iba a trabajar llorando.

\footnotetext{
${ }^{1}$ FLM5347 - Ensino, Aprendizagem e Aquisição de Espanhol como Língua Estrangeira à Luz do Pensamento Complexo, ministrada pela Profa. Dra. Fátima Aparecida Teves Cabral Bruno.

${ }^{2}$ A primeira oração foi produzida em um exercício escrito em que deveriam reformular duas orações dadas, mantendo o sentido da oração. A segunda é uma produção oral espontânea, recolhida de uma das provas orais de fim de curso.
} 
Ambos os alunos ocultaram a preposição "a" exigida pelos verbos "entregar" ("entregar algo a alguien") e "ir" ("ir a algún lugar"), e o artigo masculino "el" referente aos substantivos masculinos "profesor" e "empleo".

Oliveira (2007) relata ainda que os falantes procuram mascarar as construções relativas com, entre outras estratégias, pausa e/ou hesitação, fato também observado no mesmo trabalho final de pós-graduação:

3. Estoy con un amigo de trabajo, un español, acá en Brasil...estaba pensando en salir de viaje con...presentar las cosas de Brasil.

Observamos em (3) que o aluno começa a produzir uma oração que, provavelmente, resultaria em uma relativa padrão ${ }^{3}$, que seria:

Estoy con un amigo de trabajo, un español, acá en Brasil con el que/ con quien estaba pensando en salir de viaje y presentar las cosas de Brasil. ${ }^{4}$

Mas o aluno se detém, evitando tal estrutura e usando a pausa, estratégia citada por Oliveira.

Correa (1998) afirma que no PB os alunos evitam as construções de relativas com preposições porque são vistas como elementos da língua culta, ou

\footnotetext{
${ }^{3}$ Lembramos que a relativa padrão é referente à escrita.

${ }^{4}$ Reformulação nossa.
} 
seja, mais formais. Podemos nos perguntar até que ponto esta dificuldade pode influenciar na produção das mesmas estruturas de ELE por estudantes brasileiros.

Nas produções de nossos alunos, observamos, além de fuga da estrutura da língua culta, citada por Correa, dificuldades com o uso de algumas estruturas, como em (4a). Observamos nesta produção - como alternativa para o uso da relativa padrão (4b) - a realização de resumptivo, mas com um erro no uso do pronome pessoal "él" (4c).

4. a. Aquel que su madre le había advertido de no hablar con ello.

b. Aquel con el que su madre le había advertido que no hablara.

c. Aquel con el que su madre le había advertido que no hablara con él. ${ }^{5}$

Também observamos problemas com o uso de preposições (5a): o aluno se equivoca com o uso da regência verbal, usando a preposição "de" com o verbo "decir" em lugar de "hablar de/sobre" (5b).

5. a. [...] vio el bosque de que su mamá le había dicho.

b. [...] vio el bosque sobre el/ del que su mamá le había hablado.

\footnotetext{
${ }^{5}$ Podemos observar também que o aluno comete um erro com a regência verbal de "advertir"
} 
Percebemos também o uso equivocado do artigo em relação ao gênero. Como em PB a forma do artigo neutro não se diferencia da forma do artigo masculino, seu uso se torna complicado para um estudante brasileiro:

6. a. "Es para sentir el tuyo perfume.", "¿Y esta boca tan grande?", al que el lobo le contestó: " $i E s$ para comerte!".

b. A lo que el lobo le contestó...

A oração adequada, já que o lobo "contestó a algo" é a que usa "art. + lo + que" (6b).

Esses dados nos levaram ao interesse de investigar as orações de relativo com preposição e artigo realizadas por brasileiros adultos estudantes de ELE.

A proposta desta dissertação de mestrado é analisar essas orações em testes escritos de reformulação. A pesquisa tem os seguintes objetivos:

- Verificar se os alunos brasileiros de ELE utilizam o relativo acompanhado de preposição e artigo - quando o usam e como o fazem;

- Quais contextos favorecem a elipse de "preposição + artigo";

\footnotetext{
${ }^{6} \mathrm{O}$ aluno se equivoca quanto ao uso da forma do possessivo anteposto ao substantivo.
} 


\section{FUNDAMENTAÇÃO TEÓRICA}

\subsection{AS ORAÇÕES RELATIVAS NA GRAMÁTICA DO ESPANHOL}

\subsubsection{INTRODUÇÃO}

Brucart (1999) define as orações relativas como:

oraciones subordinadas encabezadas por un pronombre, adjetivo o advérbio relativo que actúan como complementos modificadores de un elemento llamado antecedente.

O antecedente citado pode ser um nome, um grupo nominal ou um sintagma nominal. O autor afirma também que, além dos constituintes nominais - que são mais frequentes -, também podem servir de antecedentes de uma oração relativa os pronomes pessoais, os advérbios pronominais e orações, como se mostra respectivamente nos exemplos a seguir (BRUCART, 1999, p. 398):

7. a. [Él, que no está acostumbrado a perder,] encajará este revés como una injusticia.

b. Iremos [allá dónde tú digas].

c. [Improvisó un discurso brillantísimo, lo cual provocó general admiración]. 
Para Porto Dapena (1997, p. 11) a oração relativa é:

"aquella en cuya composición entra un pronombre o adverbio relativo, esto es, una palabra gramatical con una doble misión: ser, por una parte, constituyente de dicha oración y, en segundo lugar, servir de enlace o conexión con otra, denominada oración principal, en virtud de la identidad referencial del relativo con un elemento de esta última, llamado antecedente."

Ou seja, as relativas aparecem sempre encabeçadas por um nexo subordinante vinculado/ conectado anaforicamente ao antecedente, atuando como argumento ou adjunto dentro da subordinada. Este nexo subordinante pode ser um pronome (que, quien), adjetivos (determinativos cual, cuanto e cuyo) ou advérbios (cuando, como, donde e cuan).

Ainda segundo Porto Dapena, em todas as construções de relativo existem duas orações e um constituinte em comum. No exemplo abaixo, temos duas orações independentes:

8. Ascención vive en Alpedrete.

9. Alpedrete es un bonito pueblo de la sierra. (PORTO DAPENA, 1997, p.12)

No caso da construção de relativo, uma das orações é a principal, e a que será introduzida pelo relativo, a secundária. Como as duas orações possuem em comum o constituinte "Alpedrete", podem conectar-se por um relativo. 
10. a. Ascención vive en Alpedrete, que es un bonito pueblo de la sierra.

b. Alpedrete, donde vive Ascención, es un bonito pueblo de la sierra. (PORTO DAPENA, 1997, p. 12)

Para Bello (1988) estes nexos - os relativos - são demonstrativos que reproduzem um conceito anterior e servem para enlaçar uma proposição à outra. Pode ser explicativa ou especificativa, dependendo se explica ou especifica, respectivamente, a proposição da qual esse relativo faz parte. (BELLO, 1988, p. 300):

11. Ella, que deseaba descansar, se retiró a su aposento. (Relativa explicativa)

12. Los muebles de que está adornada la casa que habitamos son enteramente conformes al gusto moderno. (Relativa especificativa)

Segundo Bello (1988), muitas vezes a estrutura explicativa, como do primeiro modelo, não se distingue da especificativa, como do segundo modelo, a não ser pela pausa que é comum na explicativa, e que na escrita se expressa através de uma vírgula (13a):

13. a. Las señoras, que deseaban descansar, se retiraron.

b. Las señoras que deseaban descansar se retiraron. (BELLO, op. cit., p. 300) 
Como esclarece o autor, o sentido da primeira oração é puramente explicativo, se fala de todas as senhoras. Já na segunda oração o sentido é especificativo, pois se entende que não todas, mas, algumas das senhoras, necessitavam descansar e que somente estas se retiraram.

Segundo Brucart (1999), quando a função gramatical ou semântica pede, esse nexo aparecerá precedido de uma preposição correspondente à função, como no exemplo a seguir (BRUCART, 1999, p. 398):

14. La persona a quien me refiero no está aquí.

Existem também alguns relativos que já possuem, incorporada ao seu conteúdo léxico, a relação semântica que geralmente é expressa por uma preposição, como o caso de "donde" (BRUCART, op. cit., p. 399):

15. El lugar [donde lo vi] era poco recomendable.

Nesta oração o uso da preposição seria redundante, como se vê em (BRUCART, op. cit., p. 399):

16. El lugar en donde lo vi era poco recomendable. ${ }^{7}$

\footnotetext{
${ }^{7}$ Expressões tratadas como redundantes precisariam ser melhor analisadas.
} 


\subsubsection{O "QUE" RELATIVO}

Brucart (1999) afirma que o relativo "que" é o nexo relativo "por defecto" em espanhol. $\mathrm{O}$ que o diferencia dos pronomes e adjetivos relativos é o fato de não apresentar características de flexão que, segundo Bello (1988), são concebidas por seu antecedente. Sua comutação por outros relativos somente é possível se uma preposição o precede:

17. El lugar donde lo encontraron era poco accesible / El lugar en el que lo encontraron era poco accesible.

No caso de que entre 0 antecedente e 0 relativo não se interponha preposição, "que" é o único pronome possível, pois "quien" e "cual" são descartados por redundância (segundo BRUCART, op. cit., p. 491):

18. a. El hombre que vino te dejó esta carta.

b. *El hombre el cual vino te dejó esta carta.

c. *El hombre quien vino te dejó esta carta.

Brucart (1999) destaca duas características do comportamento sintático do pronome relativo "que": 
1. A possibilidade de ir precedido pelo artigo determinado nos casos em que a função que desempenha deva incorporar uma preposição (19a).

2. A possibilidade de funcionar como "complemento directo" no interior da subordinada sem a necessidade de que apareça a preposição "a" que é característica de tal função quando o sintagma que a desempenha for animado e específico (19b).

O autor destaca ainda que, se o artigo aparece, a única sequência correta é a que possui a preposição, como se pode concluir a partir da agramaticalidade de (19c):

19. a. El escritor al que premiaron anoche vendrá a nuestra tertulia próximamente.

b. El escritor que premiaron anoche vendrá a nuestra...

c. ${ }^{*}$ El escritor el que premiaron anoche... 


\subsection{3. "QUE" RELATIVO X "QUE" COMPLETIVO}

Segundo Brucart (1999), a sequência "art. + que" dos exemplos abaixo corresponde a duas estruturas diferentes:

20. a. Los estudiantes que faltaron fueron más que los que asistieron.

b. El traje con el que asistió al acto era inefable. (BRUCART, 1999, p. 492)

Segundo Bello (1988), as expressões "el que", "la que", "los que", "las que", "lo que" devem ser consideradas algumas vezes como compostas de duas palavras diferentes outras vezes equivalentes a uma palavra somente. No primeiro caso o artigo está substantivado (21) e serve de antecedente ao relativo. Já no segundo caso (22), o artigo é somente uma forma do relativo, por meio da qual se determina se é um substantivo ou adjetivo, e qual é, enquanto adjetivo, seu gênero e número.

21. Los que no moderan sus pasiones son arrastrados a lamentables precipicios.

22. La relación de las aventuras de D. Quijote de la Mancha, escrita por Miguel de Cervantes Saavedra, en la que los lectores vulgares sólo ven un asunto de entretenimiento, es un libro moral de los más notables que ha producido el ingenio humano. 
A existência de amostras de "que" com e sem artigo levou alguns gramáticos a supor a existência de dois pronomes relativos diferentes. Esta é a postura adotada por Brucart (1999) em seu trabalho.

De acordo com o autor, no século XIX já se fazia a relação entre "que" pronome e "que" completivo. No século XX, a partir das propostas de Kayne (1976) para o francês e de Cinque $(1978 ; 1982)$ para o italiano, esta proposta toma novo vigor, mas com uma perspectiva diferente, que diz que o "que" é uma marca de subordinação, unicamente. O que caracterizaria as construções do "que" relativo seria a existência à frente da oração de um operador relativo vazio que representaria, na subordinada, o argumento ou o adjunto relacionado com o antecedente.

Com esta análise, em orações como (23) não há a despronominalização com resumptivo, mas sim a substituição do operador vazio pelo correspondente constituinte léxico, isto é, o resumptivo no interior da subordinada ("él" - "un asunto"), já que esse "que" nunca teria sido um pronome, mas sim um nexo subordinante. Essa análise coincide com a proposta de Tarallo (1993) para as sentenças com pronome resumptivo no PB.

23. Me hablas de un asunto que yo no puedo opinar sobre él. (BRUCART, 1999, p. 493): 
Segundo Brucart (1999), a aplicação da análise do "que" subordinante ao espanhol se deve a Rivero (1980; 1982), que propõe diferenciar duas variantes do "que" na construção relativa. A primeira variante é quando aparece precedido de preposição, com ou sem artigo. Neste caso este "que" seria um verdadeiro pronome relativo:

24. El libro con el que me obsequió estudia la pintura de Frida Kahlo. (BRUCART, 1999, p. 494).

Ainda segundo o autor, a segunda variante é quando o "que" não aparece precedido de preposição. Neste caso se trata do subordinante por excelência do espanhol e sua única função é a de servir como nexo introdutor de cláusula relativa:

25. El profesor que habla es sociolingüista.

26. Juan no es lo revolucionario que fue su padre.

27. ¿Has encontrado un libro que leer?

A partir da perspectiva de que em espanhol o operador relativo vazio que leva consigo o "que" subordinante também pode aparecer como termo de preposição, a presença de artigo determinado em tais construções resulta da conveniência de colocar na subordinada uma entidade que reitere as 
características do elemento antecedente ao não encontrar-se adjacente ao operador relativo. O fato de que isto seja possível em espanhol e não em outras línguas que usam a estratégia de construir subordinadas relativas encabeçadas pelo subordinante completivo deve ser atribuído à maior força anafórica do artigo no espanhol, que se pode comprovar na sua capacidade para encabeçar sintagmas com núcleo elíptico ("el que te regalé"/ "El de María"/ "el nuevo" BRUCART, 1999, p.494).

\subsubsection{AUSÊNCIA E PRESENÇA DE ARTIGOS NAS ORAÇÕES RELATIVAS OBLÍQUAS NO ESPANHOL}

Sobre a presença e ausência de artigos nas relativas oblíquas, Brucart (1999) afirma que com exceção dos casos de relativos como (28a), que expressam modo ou maneira, em todos os outros casos a preferência é pela relativa oblíqua com artigo: (BRUCART, op. cit., p. 494)

28. a. El modo $\{e n / c o n\}$ que fuimos tratados fue humillante.

b. ??El modo $\{$ en/con $\}$ el que fuimos tratados fue humillante.

29. a. El libro con el que me obsequió estudia la pintura de Frida Kahlo.

b. El libro con que me obsequió estudia la pintura de Frida Kahlo. 
Para que a relativa oblíqua sem artigo seja possível, devem ocorrer três condições. A primeira é que o sintagma que contém o antecedente da relativa (no exemplo a seguir: "pluma") seja de natureza definida ("la pluma" e não "una pluma"), como podemos comprovar com a agramaticalidade de (30c):

30. a. Le regalé la pluma con que había escrito algunas de mis novelas.

b. Le regalé la pluma con la que había escrito algunas de mis novelas. c. *Le regalé una pluma con que había escrito algunas de mis novelas.

d. Le regalé una pluma con la que había escrito algunas de mis novelas. (BRUCART, op. cit., p. 494)

Brucart (1999) afirma que é possível que esta restrição derive do caráter intrinsecamente determinado do relativo. Nos casos em que o antecedente faz parte de um sintagma definido, o relativo não precisa reiterar tal caráter (30a). Por outro lado, quando o antecedente está contido em um sintagma não definido, é necessário marcar o caráter definido que esse sintagma tem dentro da subordinada, por meio do artigo (30d).

A segunda condição corresponde à polaridade da subordinada, que não pode ser negativa (BRUCART, op. cit., p. 495):

31. a. *Mi padre me prestó el dinero de que yo no disponía.

b. Mi padre me prestó el dinero del que yo no disponía. 
No exemplo (31), segundo Brucart (1999), como a polaridade da subordinada é negativa ("yo no disponía"), é agramatical a ausência do artigo definido "el" junto à preposição (31a).

A terceira condição diz respeito à preposição que encabeça a subordinada: somente um subconjunto limitado delas pode aparecer nas relativas oblíquas sem confluir com o artigo determinado: "a", "con", "de" e "en" (e em menor medida, "por") e, segundo Brucart (op. cit.), não é fácil determinar quais preposições podem contribuir para a lista anterior. Retomamos este ponto no capítulo seguinte.

\subsubsection{AUSÊNCIA E PRESENÇA DE PREPOSIÇÕES NAS ORAÇÕES RELATIVAS OBLÍQUAS NO ESPANHOL}

Algumas gramáticas mencionam critérios de índole silábica, a homonímia e critérios léxico-semânticos como importantes para determinar a presença da preposição.

As gramáticas do espanhol relacionam a tendência a suprimir a preposição quando a mesma entidade aparece também ante o antecedente como 
consequência de um regime do verbo principal, como no exemplo a seguir (BRUCART, 1999, p. 496):

32. a. Unos vamos vestidos con los mismos vestidos con los que representamos.

b. Unos vamos vestidos con los mismos vestidos que representamos.

O autor também recorda que, como dito anteriormente, antecedentes como "modo", "manera" e "forma" tendem a requerer a construção sem artigo, o que está provavelmente relacionado com a natureza predicativa de tais elementos (BRUCART, 1999, p.496):

33. Nos trató de forma indigna - La forma indigna en que nos trató

Além disto, Brucart (op. cit.) aponta também que nem todos os contextos em que aparecem as preposições capacitadas para encabeçar relativas oblíquas com "que" sem artigo admitem com igual naturalidade tais construções. Como no exemplo (BRUCART, op. cit., p.491):

34. *El escritor a que premiaron anoche vendrá a nuestra tertulia próximamente.

A preposição "a" de acusativo não pode fazer parte da construção (34), assim como a preposição "a" de dativo não se acomoda facilmente a: 
35. *La persona a que entregaron el libro. (BRUCART, 1999, p. 496)

As gramáticas prescritivas e descritivas (RAE, 1973; SOLÉ y SOLÉ, 1977) diferenciam os antecedentes [humanos] nas relativas onde o pronome funciona como objeto indireto $(\mathrm{OI})$ da subordinada. As gramáticas especificam duas situações para os antecedentes [+humanos]: quando o antecedente é um pronome indefinido ("alguien" ou "nadie"), "quien" é a única possibilidade (36), mas com todos os outros, é possível escolher entre "quien", "art + que" ou "art + cual" (37). Com antecedentes [-humanos] é possível usar tanto "art. + que" quanto "art. + cual" precedidos por "a" (38).

36. No encuentro a nadie a quien le encargaría eso.

37. La persona a quien / a la que / a la cual le mandaron la carta bomba llamó a la policía.

38. El museo al que / al cual le dejó su dinero le dedicó una placa. (Suñer, 2001, p. 17)

Mas Suñer (2001), em seu estudo sobre as orações relativas especificativas no espanhol de Caracas, não registrou nenhum caso de "quien" com função de Ol, mesmo estudando um corpus com quase 100\% das orações relativas contendo antecedente [+humano]. O que mostra uma variação entre o uso e as gramáticas. 
Seu trabalho comprova que o tipo mais comum de relativa especificativa é o que a autora chama de "que escueto" ${ }^{8}$, ou seja, não precedido de preposição ou outra partícula que se assemelhe a uma preposição, como a "a" dativa ou acusativa. Ressalta também que o uso de tais relativas está crescendo na linguagem coloquial oral e escrita.

Embora estude um corpus de Caracas, a autora afirma que os dados de seu trabalho podem ser generalizáveis, pois comparando os dados de seu corpus aos corpora de Verdonk (1992), peninsular e latino-americano, e Eberenz (1983), peninsular escrito, encontrou paralelismos que considerou como "assombrosos", dada a natureza tão diferente dos mesmos. Assim, nos valeremos dos dados de Suñer (2001) para nossas análises.

Ainda segundo a autora, o pronome relativo mais frequente é "(art.) que", com 114 casos, e em somente 12 deles (10,53\%) co-aparece o artigo. Isso indica que "preposição + que" é o relativo mais comum nas frases preposicionadas $(89,47 \%)$.

Em seus dados, pôde observar três tendências nas frases preposicionadas: somente cinco preposições precedem o pronome relativo ("en",

\footnotetext{
${ }^{8} \mathrm{O}$ "que escueto" de Suñer se refere ao que neste trabalho chamaremos de "cortadora".
} 
"de", "a", "con" e "por"); em 68 dos casos a preposição é nula; a preposição mais comum é "en" (90 casos: 62,5\%), seguida de longe por "de" (22 casos).

Ainda, embora as gramáticas afirmem que qualquer preposição pode ser nula quando o antecedente é introduzido por uma preposição idêntica, como vimos no inicio deste capitulo, na maioria dos casos do corpus de Caracas, a autora observa o uso duplicado da preposição "en" (SUÑER, 2001, p. 23):

39. [ ...] en la medida en que él no entienda...

A autora observou a omissão de preposição em $47,22 \%$ das relativas preposicionais, unicamente com o relativo "que". Como causa dessa omissão, cita cinco fatores:

1. Presença da mesma preposição com o antecedente:

40. [...] en la única materia [en] que llevo más de quince es inglés. (SUÑER, op. cit., p. 22):

2. Interpretação temporal, locativa ou de maneira, onde "en que" é equivalente a "cuando", "donde" ou "como". 
41. [...] esas descripciones... [en] que me describen una situación... (SUÑER, 2001, p. 23):

3. Verbos de regime: já que estes verbos selecionam uma preposição específica, sua ausência é completamente recuperável (42). Os verbos citados pela autora são: "meterse en", "basarse en", "hablar de", "acordarse de", "enfrentarse a", "limitarse a" e "ir a".

42. [...] otras carreras [en] que uno puede meterse. (SUÑER, op. cit., p. 23).

4. Expressões ou frases feitas que selecionam preposições específicas: "estar de acuerdo con", "hacer amistad con", "sentirse mal con", "pagar $\mathrm{X}$ por $\mathrm{Y}$ ", "poner $\mathrm{X}$ en Y":

43. [...] lo único [con] que no estoy de acuerdo...

44. [...] la señora del frente como tiene la luz [por la] que no paga nada... (SUÑER, op. cit., p. 24).

5. "Estratégia de retoma", ou copiadora / resumptivo, que a autora cita como minoritários, dado que foram encontrados somente três exemplos em seu corpus:

45. [...] eso es un país que hablan tanto de él... (SUÑER, op. cit., p. 24) 
A autora afirma, também, que a preposição não tem conteúdo léxico (é nula) em 68 dos casos, número próximo aos 76 casos nos quais a preposição é visível. O que demonstra que a preposição nula é muito mais frequente na fala do que os gramáticos imaginam.

Afirma também que a primeira coisa que the chamou atenção é que $91,11 \%$ dos casos de relativas aparece com antecedente [- humano] e apenas $8,88 \%$ com o antecedente [+ humano]. A preposição mais comum com os antecedentes [+ humano] é "a". Também observou que "prep. + que" aparece três vezes em seus dados, a pesar do que dizem as gramáticas.

Segundo Suñer (2001, p. 20):

Ramsey (1956:196) escribe: que regido por una preposición no se usa para personas, debe usarse quien, una aseveración que repiten Solé y Solé (1977:117).

A autora complementa que em seus dados, não aparece nenhuma amostra de preposição léxica com "que", por outro lado, sete dos treze casos com antecedente [+ humano] aparecem com o "que escueto":

46. [...] de las personas [con] que [...] hicimos amistad. 
A autora conclui que os paralelismos encontrados em seu corpus de Caracas e os corpora escritos pandialetais ${ }^{9}$ parecem sugerir que os resultados e tendências observados são generalizáveis independente da modalidade usada.

\footnotetext{
${ }^{9}$ A autora compara seu corpus aos corpora de Verdonk (1992) - peninsular e latino-americano; e Eberenz (1983) - peninsular escrito, como visto no cap. 2.1.5.
} 


\subsection{AS ORAÇÕES RELATIVAS NA GRAMÁticA DO PORTUGUÊS BRASILEIRO}

\subsubsection{INTRODUÇÃO}

No Português do Brasil (PB), Tarallo (1993) investiga as estratégias de relativização na variante falada na área urbana de São Paulo. Segundo o autor, há três tipos diferentes de cláusula relativa:

1. Variante com lacuna - quando há uma lacuna na cláusula relativa na posição original do SN-qu. São, ao menos superficialmente, idênticas a cláusulas relativas encontradas na língua escrita padrão (TARALLO, op. cit., p. 41):

47. Tem as (e) que não estão nem aí, não é?

A lacuna está indicada por (e) -e do inglês empty, vazio- na posição do sujeito do verbo subordinado.

2. Pronome resumptivo - este segundo tipo não envolve lacuna. A posição da lacuna é preenchida por uma forma pronominal co-referente com o SN núcleo da relativa (TARALLO, op. cit., p. 41): 
48. Você acredita que um dia teve uma mulher que ela queria que a gente entrevistasse ela pelo interfone.

49. E um deles foi esse fulano aí, que eu nunca tive aula com ele.

A estratégia do pronome resumptivo ocorre na escala sintática inteira; já a variante com lacuna ocorre somente nas posições de sujeito e de objeto direto. Para as posições sintáticas mais baixas, como objeto indireto, objetos de preposição (oblíquos) e genitivos, a gramática padrão prescreve o uso de relativas piedpiped, conforme o exemplo (TARALLO, 1993, p.41):

50. E um deles foi esse fulano aí, com quem eu nunca tive aula.

Tarallo emprega o termo piedpiped ${ }^{10}$ utilizado na bibliografia gerativista para indicar que a análise que está sendo feita é a de uma estrutura em que o sintagma preposicionado é movimentado junto com o relativo, de um lugar de origem dentro da relativa até a posição inicial da subordinada.

3. Relativa cortadora - ocorre somente quando o $\mathrm{SN}$ relativizado é o objeto de uma preposição e neste tipo, estão ausentes a preposição regente e o SN relativizado, sendo também uma variante com lacuna (TARALLO, op. cit., p.42):

\footnotetext{
${ }^{10}$ Metáfora que aponta para a ideia de que o relativo "leva" junto o sintagma preposicionado. 0 termo faz alusão ao conto The Pied Piper ofHamelin.
} 
51. E um deles foi esse fulano aí, que eu nunca tive aula.

De acordo com o autor, as relativas piedpiping, como em (50), não ocorrem na fala, portanto, ou a estratégia do pronome resumptivo ou a relativa cortadora realizam o papel sintático desempenhado na língua escrita padrão por piedpiping.

Ainda de acordo com Tarallo, a probabilidade dos pronomes resumptivos decresce de uma frequência muito alta com os genitivos (20\%) para razoavelmente alta com os objetos indiretos $(13,8 \%)$ e oblíquos $(7,8 \%)$, para um pouco mais baixa com os sujeitos (9\%) e para muito baixa com objetos diretos $(1,2 \%)$, para falantes de classe média e alta. Já para a classe baixa: genitivo (100\%), objeto indireto $(25,5 \%)$, oblíquo $(13,6 \%)$, sujeito $(11,3 \%)$, objeto direto $(3,6 \%)$. Ou seja, os genitivos favorecem os pronomes resumptivos e os objetos diretos os desfavorecem.

Sobre a porcentagem de uso das relativas cortadoras e da estratégia de pronome resumptivo, Tarallo (1983) aponta um estudo feito através de meios de mídia de caráter mais formal: jornal, documentários e mesas-redondas, onde há pouca ou nenhuma infiltração de relativas não padrão; e de caráter menos formal: de programas de esporte, talk shows e novelas, onde há uma maior produção 
dessas relativas. A porcentagem de relativas cortadoras é sempre maior que a de resumptivo nos meios de caráter menos formal, conforme tabela abaixo:

Table 5.15. Percentage of use of three relativization strategies according to media-type text

GAP-LEAVING

$\begin{array}{lccccc}\text { NW } & \text { D } & \text { R } & 5 & \text { T } & \text { N } \\ 135 & 218 & 126 & 95 & 77 & 315 \\ 100 \% & 98.2 \% & 97.7 \% & 91,3 \% & 84.6 \% & 84.7 \% \\ & & & & & \\ \text { RESTMPTIVE } & & 3 & 3 & 5 & 21 \\ 0 & 0 & 2.3 \% & 2.9 \% & 5.5 \% & 5.6 \% \\ 0 \% & 0 \% & & & & \\ \text { PP-CHOPPING } & 4 & 0 & 6 & 9 & 36 \\ 0 & 1.8 \% & 0 \% & 5.8 \% & 9.9 \% & 9.7 \% \\ 0 \% & 1.8 \%\end{array}$

\section{KEY:}

NW $=$ newspaper writing

$\mathrm{D}=$ documentaries

$\mathrm{R}=$ round tables

$\mathrm{S}=$ sportscasts

$\mathrm{T}=$ talk shows

$\mathrm{N}=$ novelas

Uma análise diacrônica sobre essa maior frequência da oração cortadora em relação ao pronome resumptivo é mostrada por Tarallo (1983) no gráfico a seguir: 


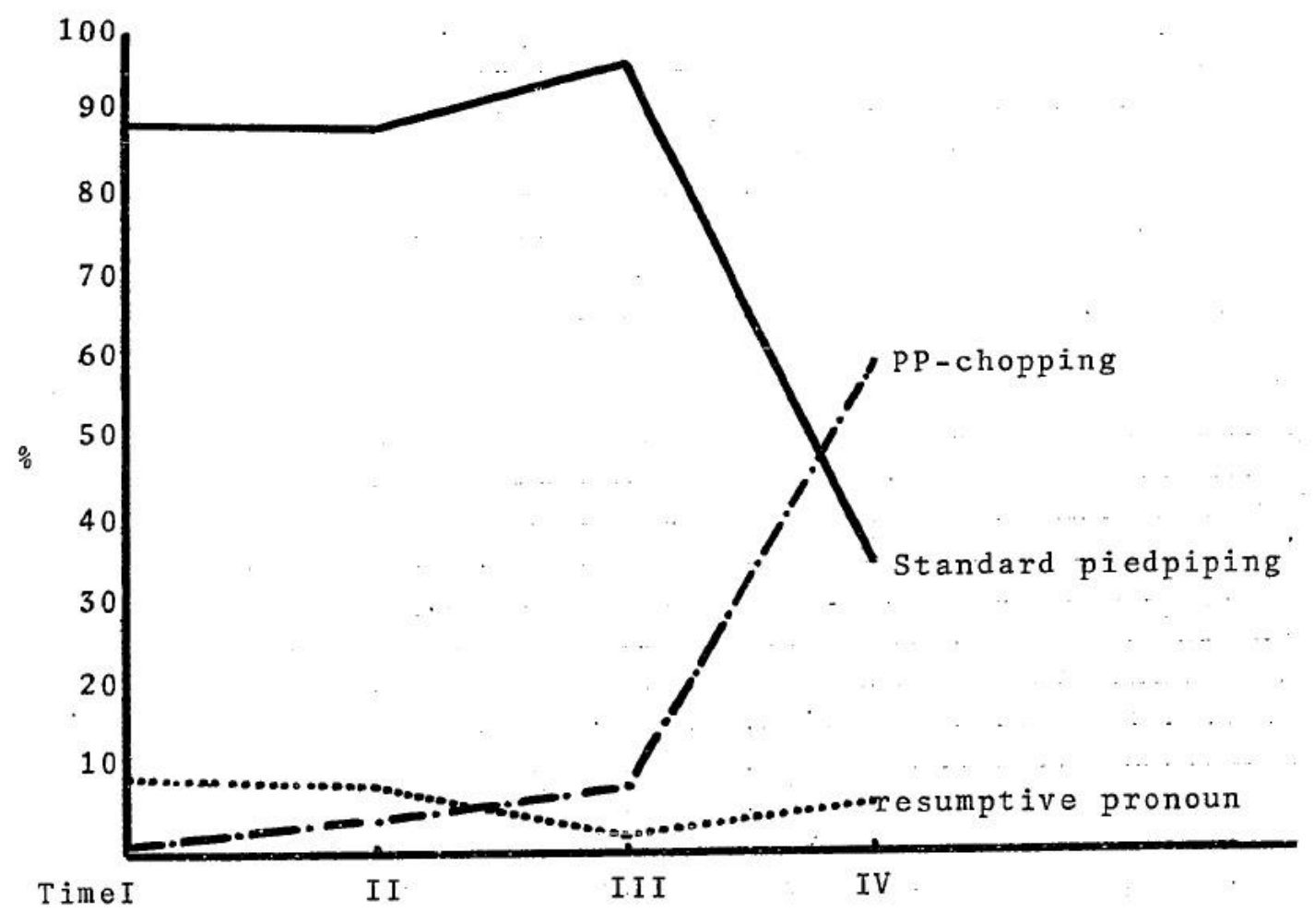

Graph 6.14. Frequency of use of three relativization strategies in indirect object, oblique, and genitive positions, across time periods

TARALLO (1983, p. 208)

Em Kato et.al. (2002) vemos que a variação nas relativas no PB pode ser estudada através de duas variáveis dependentes:

a) presença ou ausência do pronome resumptivo em todas as posições sintáticas;

b) presença ou ausência da preposição com o relativo. 
Um estudo variacionista deste tipo foi o citado anteriormente, realizado por Tarallo (1983), onde o resumptivo lexical apareceu com frequência, devido, segundo o autor, ao envolvimento de classes sociais diferentes na pesquisa, como a classe trabalhadora, de baixa escolaridade.

Já com informantes de escolaridade alta, se vê a ausência deste elemento: das 701 orações relativas apenas 10 apresentaram resumptivo lexical, 6 em função de sujeito e 4 em sintagmas preposicionais diversos.

Os autores (KATO et. al., 2002) concluíram que os fatores que induzem os falantes ao uso da preposição nas relativas são de ordem estilística e também linguística. A ordem linguística seria mais importante que a estilística. A inserção da preposição envolve um aprendizado de estratégia como um todo, o que exige do falante um nível mais alto de consciência linguística adquirido em contato com a escrita, ou seja, na escola. Mas também encontrou um alto grau de resistência à preposição em oração relativa na linguagem oral.

Perroni (2001) estuda as relativas produzidas por crianças na aquisição de PB como língua materna e afirma que, no que diz respeito a restritivas e explicativas, a maioria esmagadora das relativas produzidas é restritiva (52). Apenas poucas podem ser consideradas como explicativas (53) (PERRONI, op.cit., p. 68 e 69$)$. 
52. (Conversei) com o homem que tava aqui.

53. U meu pai, qui num tá, qui falô qui num tá suja.

Segundo a autora, o mesmo ocorre com as produções dos adultos, ou seja, realizam mais relativas restritivas.

No que concerne às relativas preposicionais, Perroni (op. cit.) afirma que as relativas "difíceis" são obviamente aquelas de sintagmas preposicionais consideradas como "padrão". Essas relativas quase inexistem na produção oral informal e a dificuldade de sua aquisição fica clara nas produções escritas.

Segundo Kenedy (2008), em seu estudo sobre as relativas preposicionadas, as relativas prepositional piedpiping ${ }^{11}$ são um objeto sintático estranho - por oposição às cortadoras, que devem ser normais - para brasileiros. Portanto, os brasileiros produziriam com mais frequência (54b) que (54a) (KENEDY, op.cit, p.12):

54. a. O menino a quem a velha deu o gato tem calças azuis.

b. O menino que a velha deu o gato tem calças azuis.

\footnotetext{
${ }^{11}$ Preposicionadas padrão
} 
Segundo o autor, os sujeitos do PB demonstraram igualmente capacidade de diferenciar com nitidez as condições expostas em seu estudo de cortadoras gramaticais e cortadoras agramaticais, mas obtiveram grande dificuldade em

diferenciar as piedpiping gramaticais das agramaticais, sendo aceitas em porcentagens muito próximas: $65 \%$ e $61 \%$, respectivamente. Isto demonstra que os brasileiros não são capazes de detectar automaticamente a agramaticalidade de preposicionadas padrão, o que significaria que já não seria uma estrutura da gramática vernácula.

\subsubsection{AS PREPOSIÇÕES NAS ORAÇÕES RELATIVAS DO PORTUGUÊS BRASILEIRO}

Segundo Tarallo (1983), os 254 casos de cortadora (PP-chopping) atestados nos dados de seu trabalho podem ser classificados nos termos de:

1. Preposições que permitem corte (chopping);

2. Números de posições argumentais que o verbo subcategoriza, permite.

A principal hipótese do autor é a de que uma maior ambiguidade será determinada por um maior número de argumentos que o verbo da cláusula relativa possa ter. 
Tarallo (1983) afirma que devido ao fato de que se perde uma grande quantidade de informação no corte das preposições de orações relativas, se espera que nem todos os verbos permitam a omissão de preposições, já que pode levar à ambiguidade.

O autor aponta algumas preposições que são geralmente cortadas, como "a", "para”, "com”, “de", “sobre", “em", "por" (TARALLO, 1983, p. 226):

The analysis of these 254 cases shows that only the following prepositions are actually chopped: $\underline{\text { a/para }}$ (= to,for); com (=with); de (=of); de/sobre (=about); em (=at, in, on); por (=for, by); and, sobre (= on). This list is by no means exhaustive, but it includes all cases of PP-chopping relatives in the data. ${ }^{12}$

Quanto aos verbos das sentenças onde foi observado o corte de preposição (PP-chopped), alguns permitiam apenas um sintagma preposicional argumental (PP-Complement), por exemplo, "interessar-se por"; outros permitiam dois ou mais sintagmas preposicionais argumentais, por exemplo, "falar com/de/para"; e um grupo deles não requeria preposição, mas ocorreu nas relativas com uma expressão locativa que permitia corte de preposição, por exemplo, "ter", "ser", "respirar".

\footnotetext{
12 "A análise destes 254 casos mostra que somente as seguintes preposições são atualmente cortadas: a/para (=to, for); com (=with); de (=of); de/sobre (=about); em (=at, in, on); por (=for, by); and, sobre (=on). Esta lista não está, de modo algum, esgotada, mas inclui todos os casos de relativas cortadoras nos dados".
} 
O grupo de verbos que requeriam apenas uma ou nenhuma preposição como complemento não produzia nenhuma ambiguidade, ou seja, a preposição era facilmente recuperável.

O autor encontrou alguns exemplos nesse grupo que podem ser prognosticados com base no traço [+/- humano] do Sintagma Nominal (SN).

Nos exemplos do autor, o traço [+ humano] do SN leva a preposição cortada a ser recuperada como "com":

55. Mas ele saiu de casa faz um seis meses; está morando com um outro rapaz que ele trabalha.(com que/quem/ o qual). (TARALLO, 1983, p. 230)

Contrariamente, o traço [- humano] do SN sugere uma interpretação semântica da preposição cortada como uma expressão locativa (em):

56. Eu só imagino uma cidade no mundo que eu moraria fora São Paulo; minto, duas; uma eu ia ficar um pouco sufocado: Paris. (em que/ na qual) (TARALLO, 1983, p. 231)

Os dados de Tarallo (1983) mostram que 76\% das preposições cortadas não resultam em ambiguidade. 
No grupo dos verbos com duas ou mais preposições como complemento, o verbo "falar" (e sinônimos) é o maior propulsor de ambiguidade. Outros verbos incluídos no mesmo grupo, como "bater", "berrar", "contar", "chegar", "descer", "perguntar", "vir", "viver", "morar" e "trabalhar" raramente causam dificuldades no processo semântico.

Sobre o uso de "quem" e "que" com preposições, Brito (1988, p. 314) afirma que:

Quando as PREPs "a" e "de" são exigidas pela regência de certos verbos, já não é tão clara a distinção entre os dois morfemas, embora, de acordo com os meus próprios juízos de gramaticalidade, as frases com antecedente [+ humano] sejam todas mais aceitáveis com o morfema "quem" do que com o morfema "que":

(vii) (=(3)) (a) Encontrei o rapaz a quem falaste ontem.

(b) ? Encontrei o rapaz a que falaste ontem,

(viii) (a) A pessoa de quem eu gosto I muito importante para mim.

(b) ? A pessoa de que eu gosto é muito importante para mim.

O mesmo contraste encontro com as PREPs "com" e "em":

(ix) (a) A pessoa com quem saíste ontem é simpática,

(x) (a) Esta é a pessoa em quem deposito toda a confiança,

\subsubsection{AS ORAÇÕES CORTADORAS NO PORTUGUÊS BRASILEIRO}

(b) ? Esta é a pessoa em que deposito toda a confiança. 
De acordo com Tarallo (1983), as relativas cortadoras representam uma opção dos falantes cultos às relativas-padrão e às relativas copiadoras (resumptivo). A relativa padrão é evitada pelo falante por fazê-lo parecer "pedante" e a relativa copiadora por parecer uma opção de um falante "pouco instruído".

Bagno (2001, p.90) diz que o Português do Brasil

é uma língua que faz amplo uso das categorias vazias e da elipse, porque o falante conta sempre com a capacidade que seu interlocutor tem de reconhecer corretamente o elemento que foi apagado, graças ao contexto verbal e não-verbal do enunciado.

O autor acrescenta que essa capacidade de reconhecimento vem da semântica do enunciado, que permite que o ouvinte interprete adequadamente os lugares deixados vazios pelo processo de apagamento da preposição. Bagno (2001) usa o verbo "gostar" como exemplo: tal verbo é usado apenas com a preposição "de" e essa característica do verbo é que permite o apagamento da preposição, evitar o deslocamento drástico da preposição imposto pela construção relativa-padrão sem que ninguém deixe de entender o que se está dizendo e escapar da construção copiadora. Esses fatores fazem da relativa cortadora a opção mais usada pelos falantes não somente na oralidade, como também em textos escritos como os encontrados pelo autor em jornais e revistas. 


\subsubsection{O ARTIGO DEFINIDO NAS ORAÇÕES RELATIVAS DO PORTUGUÊS BRASILEIRO}

Braga et.al. (2008) afirmam que, em certos contextos, o artigo definido pode ser substituído por zero:

57. [...] depois ainda tem que escovar dente para sair...éh tem que cada um pegar sua lancheira o menino pega a pasta porque ele já tem lição de casa. (BRAGA et. al., 2008, p. 93)

Para os autores, parece certo que a posição do predicativo do sujeito, quando é preenchida por substantivos que se aplicam a humanos, favorece o aparecimento de SNs sem artigo:

58. João é advogado.

59. Maria é casada. (BRAGA et. al., 2008, p. 95).

Também pode haver omissão quando há objeto direto "incorporado" ao verbo (57).

O artigo definido também pode aparecer intercalado entre um quantificador e o substantivo (60), mas, às vezes, o substantivo pode aparecer 
justaposto diretamente ao quantificador, sem o artigo (61) (BRAGA et. al., 2008, p.90):

60. [...] aí eu procurei bastante escolhi/ foi escolhida a que eles estão... como sendo na opinião de muita gente uma das melhores (escolas) et cetera et cetera... tudo que tinha....peguei todos os requisitos...fiz

61. [...] é horroroso quando eles estão fazendo programa eu tenho ido todas terças-feiras no programa que aparece no sábado.

Neste exemplo, segundo os autores, temos uma variação livre, já que se pode dizer tanto todas terças-feiras como todas as terças-feiras sem mudança de sentido. Mas isso nem sempre acontece, como podemos ver no contraste com as orações seguintes, em singular:

62. a. João trabalhou toda terça-feira. (de sua vida)

b. "João trabalhou toda a terça-feira. (das seis da manhã às 11 da noite)".

O problema do uso dos artigos nas orações relativas não parece existir para as gramáticas do PB, pois não encontramos muito material referente ao tema. O único trabalho que encontramos foi o de Brito (1988), que trata do português europeu (PE). Em sua tese, a autora nos proporciona exemplos ilustrativos dos relativos nas orações restritivas no PE. Vejamos os exemplos das possibilidades do uso do artigo nas orações que interessam especialmente para o confronto com o espanhol: 
63. a. O homem que escreveu é meu amigo.

b. *O homem quem escreveu é meu amigo.

c. ${ }^{*} \mathrm{O}$ homem o qual escreveu é meu amigo.

d. O homem que eu vi ontem é meu amigo.

e. * O homem quem eu vi ontem é meu amigo.

f. * O homem o qual eu vi ontem é meu amigo.

g. Encontrei o rapaz a quem falaste ontem.

h. Encontrei o rapaz ao qual falaste ontem.

i. ? Encontrei o rapaz a que falaste ontem.

j. Encontrei o rapaz com quem ela saiu ontem.

k. Encontrei o rapaz com o qual ela saiu ontem.

I. ?Encontrei o rapaz com que ela saiu ontem.

m. Não está aqui o cão a que costumavas fazer festas.

n. Não está aqui o cão ao qual costumavas fazer festas.

Nos três primeiros exemplos (63a, 63b, e 63c) - de relativização do sujeito - observamos que "quem" e "o qual" não podem ser usados com tal antecedente relativizado (sujeito). Essas possibilidades coincidem com aquelas que encontramos no espanhol, como podemos ver nos exemplos de Brucart (1999) já citados no capítulo 2.1.2.: 
64. a. El hombre que vino te dejó esta carta.

b. *El hombre quien vino te dejó esta carta.

c. *El hombre el cual vino te dejó esta carta.

Porém, no caso de relativização de objeto direto encontramos diferenças entre o Português Brasileiro e o Espanhol. Dos exemplos a seguir, a única estrutura do E que também é possível no PB é aquela que aparece em (65b):

65. a. El escritor al que premiaron anoche vendrá a nuestra tertulia próximamente.

b. El escritor que premiaron anoche vendrá a nuestra tertulia próximamente.

c. ${ }^{*}$ El escritor a que premiaron anoche vendrá a nuestra tertulia próximamente.

d. *El escritor el que premiaron anoche vendrá a nuestra tertulia próximamente. (BRUCART, 1999: 7.5.1., exemplos 168)

O exemplo (65c) apresenta uma estrutura agramatical em E que Brito, em português, coloca como de aceitação duvidosa (63i). Trata-se de uma relativização de objeto direto com a forma "que" e a preposição "a". No caso da relativização de objeto direto com o elemento "que", no E existe a possibilidade de uso da preposição se o artigo definido estiver presente (65a), como já foi dito no subcapítulo 2.1.4 deste trabalho. 
É interessante, para os objetivos deste trabalho, salientar esta diferença no caso da relativização do objeto direto nas relativas especificativas com "que".

No espanhol é possível empregar a estrutura com o "que" sem artigo e sem preposição (65b) ou empregar a estrutura "prep. $a+$ art. definido + que". Mas no português não é possível empregar a estrutura "prep. $a+$ artigo definido + que" no caso da relativização do objeto direto. Vamos lembrar que são raras as construções de objeto direto preposicionado no português de hoje.

Nas orações em que o relativo está antecedido de preposição, como nos exemplos (63j) a (63l) de Brito, o artigo só aparece com o relativo "qual", como mostram os exemplos (63h) e (63k). A autora afirma também que "que" usa-se, em geral, com antecedente [- humano], como demonstra em (63i) e (66).

66. Foi muito atribulada a semana em que ele veio. (BRITO, 1988, p. 246)

Brito afirma ainda que, no Português e no Castelhano, o morfema "que" precedido de preposição não possui traços de concordância e a inexistência desses traços parece justificar que alguns falantes produzam orações utilizando esse morfema com antecedente [+ humano] plural em contraste com antecedente [- humano] singular, como vemos nos exemplos (63j, 63l, 67).

67. Encontrei os rapazes com que ela saiu ontem. (BRITO, 1988, p. 271) 
Sem dúvida a gramática do português apresenta diferenças importantes em relação à gramática do espanhol quanto às características do artigo definido. O tema é profundo e ultrapassa os propósitos deste trabalho. Aqui vamos descrever as possibilidades a respeito da presença / ausência do artigo definido nas orações relativas que constituem o âmago desta pesquisa. 


\section{METODOLOGIA}

Para alcançar os objetivos propostos (ver cap. I) realizamos um trabalho empírico que será descrito neste capítulo. Os testes foram realizados com 23 estudantes de ELE, brasileiros adultos e seis nativos de E, argentinos, adultos. No total, são 29 informantes.

\subsection{INFORMANTES}

Para nossa pesquisa, utilizaremos um corpus escrito recolhido de quatro grupos distintos: dois grupos de estudantes dos cursos regulares do Centro de Línguas (CL) da FACULDADE DE FILOSOFIA, LETRAS E CIÊNCIAS HUMANAS (FFLCH), do DEPARTAMENTO DE LETRAS MODERNAS (DLM) da UNIVERSIDADE DE SÃO PAULO (USP), um grupo do curso de Graduação em Língua Espanhola do DLM, da FFLCH, USP, e, finalmente, um grupo de falantes nativos de língua espanhola.

Os grupos ficam identificados como:

- Grupo A: grupo de espanhol como língua estrangeira (ELE), do curso regular do Centro de Línguas (CL) da FFLCH. Trata-se de um grupo de 
sete estudantes adultos, de nível intermediário (Espanhol III), com uma média de 135 horas de exposição à língua.

- Grupo B: grupo de espanhol como língua estrangeira (ELE) do curso regular do Centro de Línguas (CL) da FFLCH. Trata-se de um grupo de nove estudantes adultos, de nível intermediário (Espanhol IV), com média de 180 horas de exposição à língua.

- Grupo C: grupo de graduação em Letras - Língua Espanhola do curso regular da FFLCH-USP. Trata-se de um grupo de sete estudantes adultos, cursando o sexto semestre de curso ( $4^{\circ}$ semestre de língua espanhola) com média de 210 horas de exposição à língua.

- Grupo D: grupo de seis nativos de língua espanhola, argentinos, adultos, com heterogeneidade em relação à profissão e pouco ou nenhum contato com a língua portuguesa do Brasil (PB).

\subsection{CORPUS}

A coleta de dados foi feita da seguinte maneira: entregamos uma ficha de dados para ser preenchida pelos estudantes de ELE e também pelos nativos de $E$ a fim de que nos ajudasse a conhecer melhor nossos informantes e usar essas 
informações nas análises posteriores dos dados. No que se refere aos estudantes de ELE, a ficha de dados nos ajudou a investigar o verdadeiro contato que possuem com a língua espanhola: se têm ou tiveram contato com hispanofalantes, se já viajaram a algum país de língua espanhola, se descendem de hispanofalantes, etc. Estes dados foram cruzados posteriormente com as amostras escritas recolhidas dos testes.

No que se refere aos nativos de $E$, a ficha de dados nos ajudou a investigar se tem algum contato com a língua portuguesa do Brasil, se já tiveram algum contato, se descendem de brasileiros, etc. Estes dados também foram cruzados com as amostras escritas recolhidas dos testes.

Os informantes responderam um teste com atividades de reformulação ${ }^{13}$, nas quais deveriam usar sua capacidade linguística para reformular orações separadas formando uma oração que contivesse uma subordinada de relativo, conservando o sentido das sentenças que lhes foram dadas.

Analisamos os dados recolhidos dos estudantes de ELE e os comparamos com as produções dos nativos de $\mathrm{E}$.

\footnotetext{
${ }^{13}$ Exercício escrito onde os alunos tiveram que reformular duas orações unindo-as e conservando seu sentido.
} 


\subsection{TESTE PILOTO}

Por meio do teste piloto, verificamos que muitos alunos de ELE, para reformular as orações, ou se esquivavam de orações relativas, ou usavam o pronome "cujo", que não era tema de nossa análise. A solução encontrada para induzi-los a construir orações relativas foi fornecer o começo de cada oração e inserir instruções no enunciado dizendo que não deveriam usar "cual", "cuyo" e "y".

Depois de realizados os testes, para a oração $A$, obtivemos a grande maioria das reformulações como orações de evitação ${ }^{14}$, tanto para estudantes de ELE como para nativos de E. A oração A era a (68a).

68. a. Ese es el profesor. A él le debes entregar una reseña semanalmente.

b. El profesor pide para entregarle una reseña semanalmente porque es muy exigente. (estudante de ELE)

c. El profesor ese es muy exigente, semanalmente le debes entregar una reseña. (Nativo de E)

d. El profesor al que le debes entregar una reseña semanalmente es muy exigente. (estudante de ELE)

e. El profesor a quien le debes entregar una reseña es muy exigente. (estudante de ELE)

\footnotetext{
${ }^{14}$ Lembramos que o falante talvez não esteja "evitando" as orações relativas conscientemente. Talvez não possua essa estrutura em sua gramática.
} 
f. El profesor a quien debemos entregar una reseña semanalmente es muy exigente. (nativo de $\mathrm{E}$ )

g. El profesor pide para entregarle una reseña semanalmente porque es muy exigente. (estudante de ELE)

h. El profesor ese es muy exigente, semanalmente le debes entregar una reseña. (nativo de $\mathrm{E}$ )

Os informantes deveriam produzir orações com a preposição "a", pertencente à regência verbal: "entregar a alguien" e o começo de oração fornecido aos informantes foi: "El professor...", portanto, uma das reformulações pensadas poderia ser: "El professor a quien le debes entregar una reseña semanalmente es ese" ou "El professor al que le debes entregar una reseña semanalmente es ese". Mas observamos reformulações como (68b) e (68c).

Observando os dados dos estudantes brasileiros, pensamos primeiramente que o grande número de orações de evitação era causado pela dificuldade em produzir orações relativas com a preposição "a", mas observando em conjunto os dados dos nativos de $E$, que também nos apresentaram, em sua maioria, orações de evitação, presumimos que se tratava também de um problema de reformulação do exercício.

Não apareceram amostras de cortadoras nas reformulações - que a bibliografia pertinente ao tema refere como sendo muito comuns na oralidade -, tampouco orações com preposição e sem artigo. Mas 6,9\% do total de 
informantes - todos brasileiros - reformularam as orações usando o modelo padrão (prep. + art.) que não é um tipo de oração relativa muito usada, por se tratar de uma oração considerada como formal (68d).

A variante "prep. + quien" também foi usada por 6,9\% dos informantes, um estudante de ELE (68e) e outro nativo de E (68f).

Já as orações de evitação, em que o informante parece procurar não realizar determinada estrutura, foram usadas em $86,2 \%$ dos casos, o que nos mostra a dificuldade que tiveram em produzir uma relativa a partir das orações do teste $(68 \mathrm{~g})$ e (68h).

Devido a essa dificuldade por parte dos dois grupos de informantes (estudantes brasileiros e nativos de E), decidimos eliminar os dados obtidos para a oração "A" de nossa pesquisa. 


\subsection{TRABALHO EMPÍRICO - TESTE}

Os informantes - tanto brasileiros quanto nativos de espanhol - deveriam reformular duas orações unindo-as em uma e conservando seu sentido. Para tanto, depois de algumas conclusões a partir de nosso teste piloto, o enunciado informava que não poderiam usar "cual", "cuyo" ou "y". As instruções também traziam o inicio de cada oração, para induzir os informantes a produzirem mais facilmente a estrutura de relativo desejada.

As orações foram escolhidas levando em conta a regência verbal, a fim de verificar o uso de determinadas preposições pelos informantes. Para tanto, nos guiamos pelo trabalho de Tarallo (1983) para a escolha das preposições, de acordo com a facilidade de omissão de determinadas preposições, citada pelo autor. As orações usadas para reformulação foram as seguintes:
A Ese profesor es muy exigente. A él le debes entregar una reseña
B Vivo en un edificio muy antiguo. El edificio tiene un ascensor que nunca funciona.
C Esta empresa va a cerrar. En esta empresa trabajo hace 10 años.
D Mi mujer es linda. Estoy casado con ella hace 20 años.
E Este traje es azul. Con este traje Julio visitó a su abuela.
F $\quad$ La casa era muy grande. Yo viví allí. 
G Hablábamos de una mujer. Esa mujer no era Juana.

H La niña usa gafas. A ella le di un helado.

I Con aquella tableta había escrito algunas de mis novelas. Le regalé la tableta a Luís.

J Mi padre me prestó el dinero. Yo no disponía del dinero.

Como vimos anteriormente, a oração para reformulação "A" foi excluída por apresentar como resultado, em sua maioria, tanto para informantes brasileiros quanto nativos de $\mathrm{E}$, orações de evitação, devido à dificuldade do uso de orações relativas a partir das duas orações dadas para reformulação.

\subsection{ORGANIZAÇÃO DOS DADOS PARA A ANÁLISE}

Os dados foram separados por oração e expressos em gráficos. Separamos também os dados dos informantes brasileiros dos dados dos informantes nativos de E. Assim, pudemos analisar melhor o que cada grupo produziu para cada reformulação e contrastar as diferenças nas suas produções. 


\section{OS DADOS}

A seguir são apresentados os gráficos e a análise dos resultados separados por subcapítulos.

\subsection{REFORMULAÇÕES DA ORAÇÃO B}

Oração B:

Vivo en un edificio muy antiguo. El edificio tiene un ascensor que nunca funciona.

\subsubsection{Gráfico das reformulações dos estudantes brasileiros de ELE}

Os informantes produziram os seguintes tipos de orações:

— Com preposição + artigo + que (padrão): não houve ocorrência.

- Advérbio donde sem preposição: El edificio donde vivo es tan antiguo que tiene un ascensor que nunca funciona.

- Com preposição e sem artigo: El edificio en que vivo es tan antiguo que tiene un ascensor que nunca funciona. 
Sem preposição (cortadora): El edificio que vivo es muy antiguo, él tiene un ascensor que nunca funciona.

Evitação: El edificio tiene un ascensor que nunca funciona, por ser antiguo.

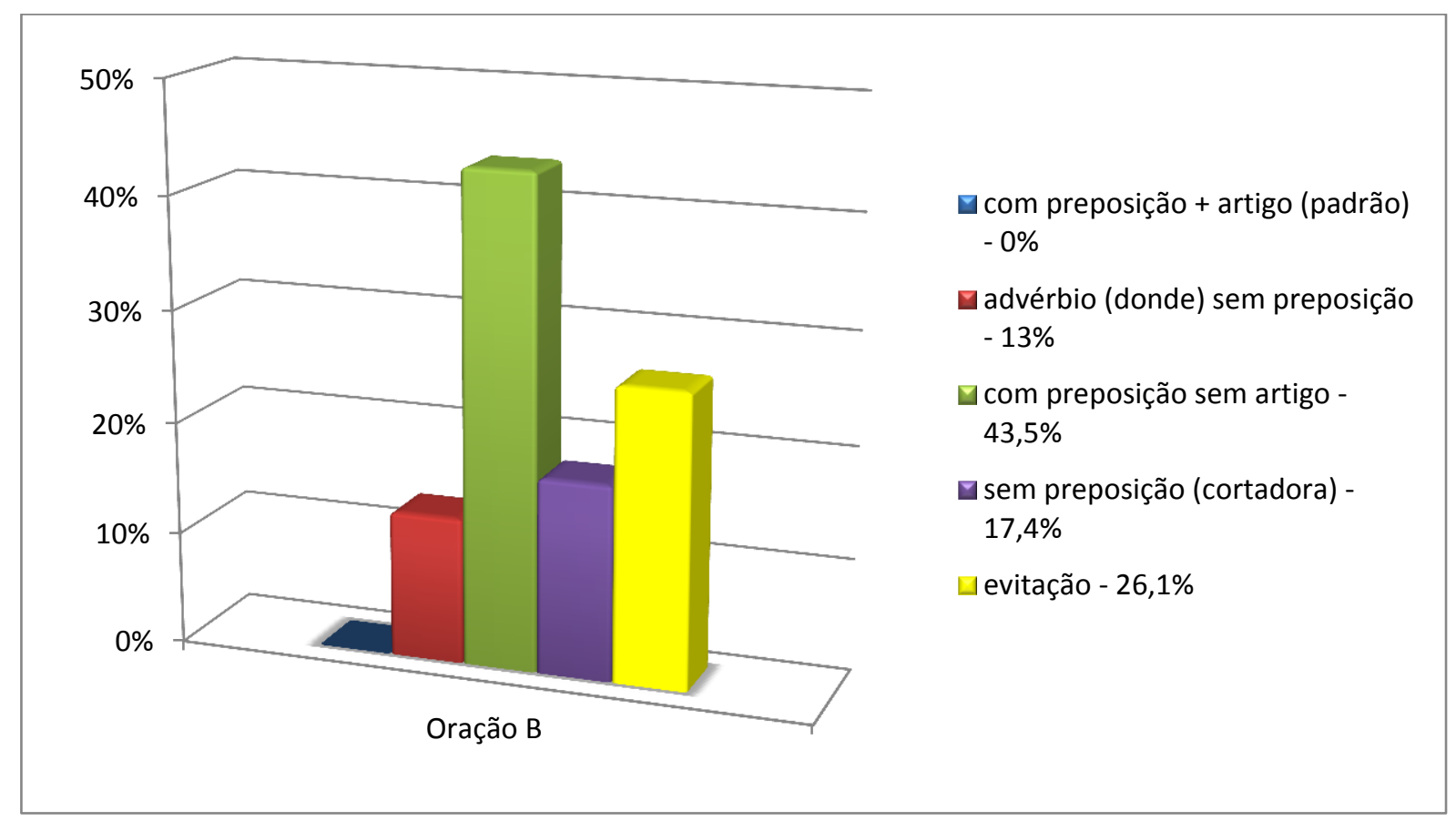

Gráfico 1 - Reformulações dos estudantes brasileiros de ELE para a oração B

Nos dados dos alunos brasileiros, observamos uma alta ocorrência $(43,5 \%)$ de relativas com preposição e sem artigo, seguidas pelas orações de evitação $(26,1 \%)$, pelas orações sem preposição (cortadoras) $(17,4 \%)$ e com maior "distância" pelas orações com advérbio "donde" sem preposição (13\%). Não houve incidência de oração padrão com "prep. + art.”. 
O alto índice de orações sem artigo (69) pode estar relacionado ao fato de que, como visto anteriormente ${ }^{15}$, em português é possível a omissão do artigo definido sem prejudicar o caráter definido do antecedente, neste caso, "edificio".

69. El edificio en que vivo es tan antiguo que tiene un ascensor que nunca funciona.

Pareceu-nos interessante o alto índice de orações de evitação. Pudemos observar que em todas as amostras de evitação, o informante escolheu expressar uma relação de causalidade existente entre as duas orações. Alguns informantes usaram o conector de causalidade "pues" (70) e outros, o sintagma preposicionado "por" (71), evitando assim, a conexão que se realizaria com uma oração relativa.

70. El edificio tiene un ascensor que nunca funciona, pues es un edificio muy antiguo.

71. El edificio tiene un ascensor que nunca funciona, por ser antiguo.

Possivelmente os informantes sentiram a necessidade de tornar explícita essa relação causal e isso pode ter levado à construções com uma estrutura mais simples, como as de evitação com um conector ou sintagma preposicional em lugar da estrutura padrão com a adição de outra subordinada.

\footnotetext{
${ }^{15}$ Ver subcap 2.2.3 deste trabalho.
} 
Os resultados foram diferentes do que esperávamos, já que a opção cortadora, segundo Tarallo (1983) e Kenedy (2008) ${ }^{16}$, costuma ser a mais usada pelos falantes de PB.

Não observamos nenhuma amostra de oração padrão com "que": "en el que", o que já esperávamos por se tratar do tipo de oração que a bibliografia pertinente assinala como a menos usada ${ }^{17}$, pois segundo Kenedy (2008), estas não seriam estruturas da gramática vernácula do $\mathrm{PB}^{18}$.

\subsubsection{Gráfico das reformulações dos Hispanofalantes}

Os informantes produziram os seguintes tipos de orações:

- Com preposição + artigo + que (padrão): El edificio en el que vivo es muy antiguo por lo tanto tiene un ascensor que nunca funciona.

- Advérbio donde sem preposição: El edificio donde vivo es muy antiguo, tiene un ascensor que nunca funciona.

- Com preposição e sem artigo: não houve ocorrência.

- Sem preposição (cortadora): não houve ocorrência.

\footnotetext{
${ }^{16}$ Ver subcap. 2.2.1 e 2.2.2.1 deste trabalho.

${ }^{17}$ Ver subcap. 2.2.1 deste trabalho.

${ }^{18}$ Ver cap. 2.2.
} 
Evitação: El edificio tiene un ascensor que nunca funciona, pues vivo en un edificio muy antiguo.

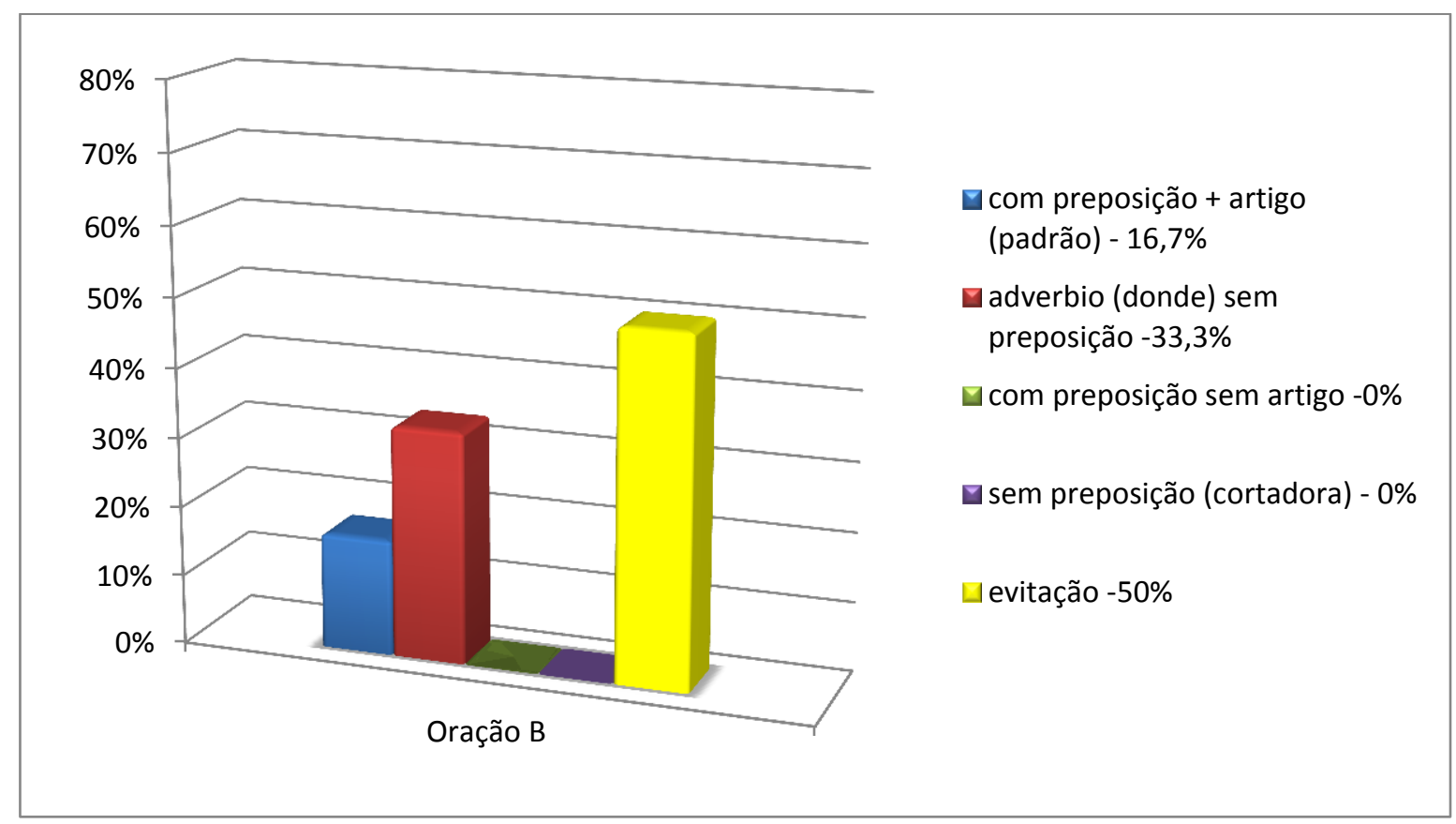

Gráfico 2 - Reformulações dos Hispanofalantes para oração B

Os nativos não produziram estruturas cortadoras neste caso. A porcentagem maior correspondeu às estruturas de evitação $(50 \%)$ e com o advérbio "donde" (33,3\%). Em menor número, observamos o uso de oração padrão com "prep. en + art. el":

72. El edificio en el que vivo es muy antiguo por lo tanto tiene un ascensor que nunca funciona. 
Pudemos constatar que no Espanhol existe a preferência pela relativa oblíqua com artigo quando há a presença de preposição (Brucart, 1999), como foi dito anteriormente, já que não foi observado o uso de oração com "prep. sem art.".

Nestes dados, nos chama a atenção o alto número de orações de evitação:

73. El edificio donde vivo es muy antiguo, tiene un ascensor que nunca funciona.

É possível verificar que os nativos de E, para esta reformulação, preferiram a evitação, enquanto os estudantes brasileiros tiveram o maior número de produções com preposição (en) e sem artigo (el):

74. El edificio en que vivo es tan antiguo que tiene un ascensor que nunca funciona.

É interessante perceber que, assim como nos dados dos estudantes brasileiros, todas as orações de evitação produzidas contêm algum elemento que explicita causalidade:

75. El edificio tiene un ascensor que nunca funciona que vivo en un edificio muy antiguo.

76. El edificio tiene un ascensor que nunca funciona, pues vivo en un edificio muy antiguo. 
77. El edificio tiene un ascensor que nunca funciona porque vivo en un edificio muy antiguo.

Um dos informantes realizou uma relativa padrão com "prep. + art." e adicionou ainda um conector causal (78) e outro informante usou o advérbio donde acrescentando também um conector causal (79):

78. El edificio en el que vivo es muy antiguo por lo tanto tiene un ascensor que nunca funciona.

79. El edificio donde vivo es muy antiguo ya que tiene un ascensor que nunca funciona.

Comparando os dois gráficos para a oração $\mathrm{B}$, vemos que tanto os brasileiros como os nativos produziram orações de evitação, todas de causalidade. Para os nativos, essas orações foram as mais produzidas $(50 \%)$, mas para os brasileiros, a porcentagem foi de $26,2 \%$. O índice mais alto para os informantes brasileiros foi o de oração com "prep. sem art." (43,5\%), que não foi realizada pelos nativos.

Os dois grupos realizaram orações com o advérbio "donde", com porcentagens diferentes: $13 \%$ para os brasileiros e $33,3 \%$ para os nativos; e somente os brasileiros realizaram orações cortadoras $(17,4 \%)$. 
O menor índice de orações de evitação realizadas pelos brasileiros pode estar relacionado ao caráter locativo da oração, que possibilitou a realização de orações com "prep. sem art.", não realizadas pelos nativos. Retomamos este pensamento na análise da oração J. 


\subsection{REFORMULAÇÕES DA ORAÇÃO C}

\section{Oração C:}

Esta empresa va a cerrar. En esta empresa trabajo hace 10 años.

\subsubsection{Gráfico das reformulações dos estudantes brasileiros de ELE}

Os informantes produziram os seguintes tipos de orações:

- Com preposição + artigo + que (padrão): La empresa en la que trabajo hace 10 años va a cerrar.

- Advérbio donde sem preposição: La empresa donde trabajo a 10 años va a cerrar.

- Com preposição e sem artigo: La empresa em que trabajo hace 10 años irá cerrar.

- Sem preposição (cortadora): La empresa que trabajo hace 10 años va a cerrar.

Evitação: não houve ocorrências. 


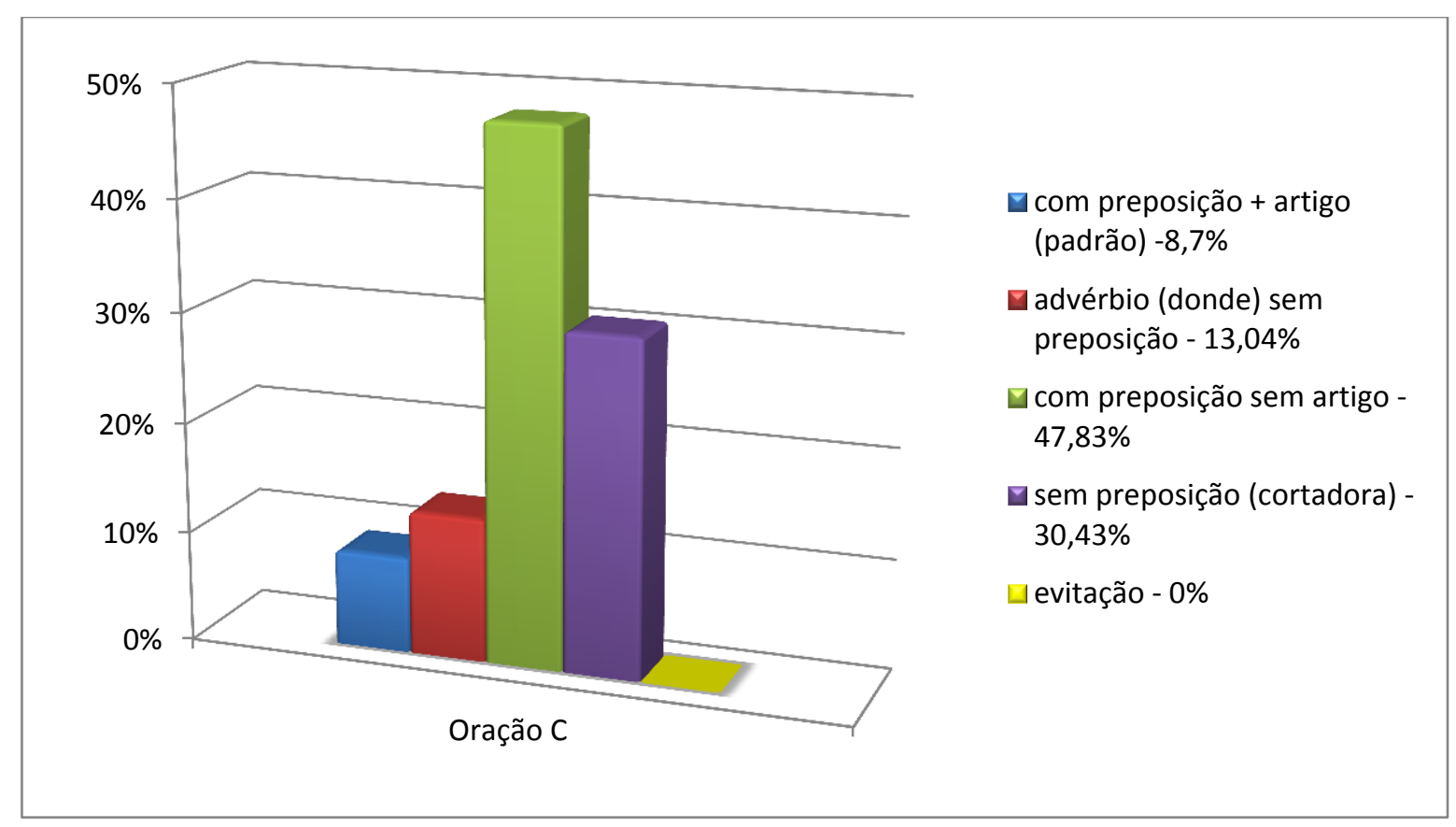

Gráfico 3 - Reformulações dos estudantes brasileiros de ELE para a oração C

Para esta oração, novamente quase a metade dos informantes $(47,83 \%)$ usou as orações com preposição e sem artigo para a reformulação, em segundo lugar aparecem as orações cortadoras $(30,43 \%)$, que não foram usadas com tanta frequência nas reformulações da oração B. A opção de evitação não foi observada, o que nos mostra que não houve maiores dificuldades com o uso das relativas nestas reformulações.

Embora as duas reformulações ( $B$ e $C$ ) deveriam ser feitas com a preposição "en", no caso da sentença $C$ não existe a relação de causalidade que pode ser interpretada em B. Isso pode ter levado aos resultados diferentes. 
A diferença fundamental entre os resultados das duas reformulações está no alto número de evitações de $\mathrm{B}$, que pode ser explicado pela dificuldade de realizar a relativa e, ao mesmo tempo, satisfazer a necessidade de explicitar a causa, como foi sugerido na análise de B.

As orações com preposição e sem artigo foram novamente as mais produzidas pelos informantes:

80. La empresa en que trabajo hace 10 años va a cerrar.

Este tipo de reformulação teve uma maior porcentagem de produção que a oração cortadora. As orações cortadoras apareceram em 30\% das orações em comparação com $48 \%$ das orações com preposição e sem artigo e somente $8,7 \%$ preferiu a opção padrão, o que já esperávamos.

Novamente os alunos brasileiros preferiram a opção com "prep. sem art." à cortadora, talvez porque, para alguns, o corte da preposição poderia causar ambiguidade devido às outras preposições que poderiam também complementar o verbo "trabajar". 


\subsubsection{Gráfico das reformulações dos Hispanofalantes}

Os informantes produziram os seguintes tipos de orações:

- Com preposição + artigo + que (padrão): La empresa en la que trabajo hace 10 años, va a cerrar.

- Preposição + advérbio donde: La empresa en donde trabajo hace diez años va a cerrar.

- Com preposição e sem artigo: não houve ocorrência.

- Sem preposição (cortadora): La empresa que trabajo hace diez años va a cerrar.

Evitação: La empresa va cerrar, es donde trabajo desde hace 10 años. 


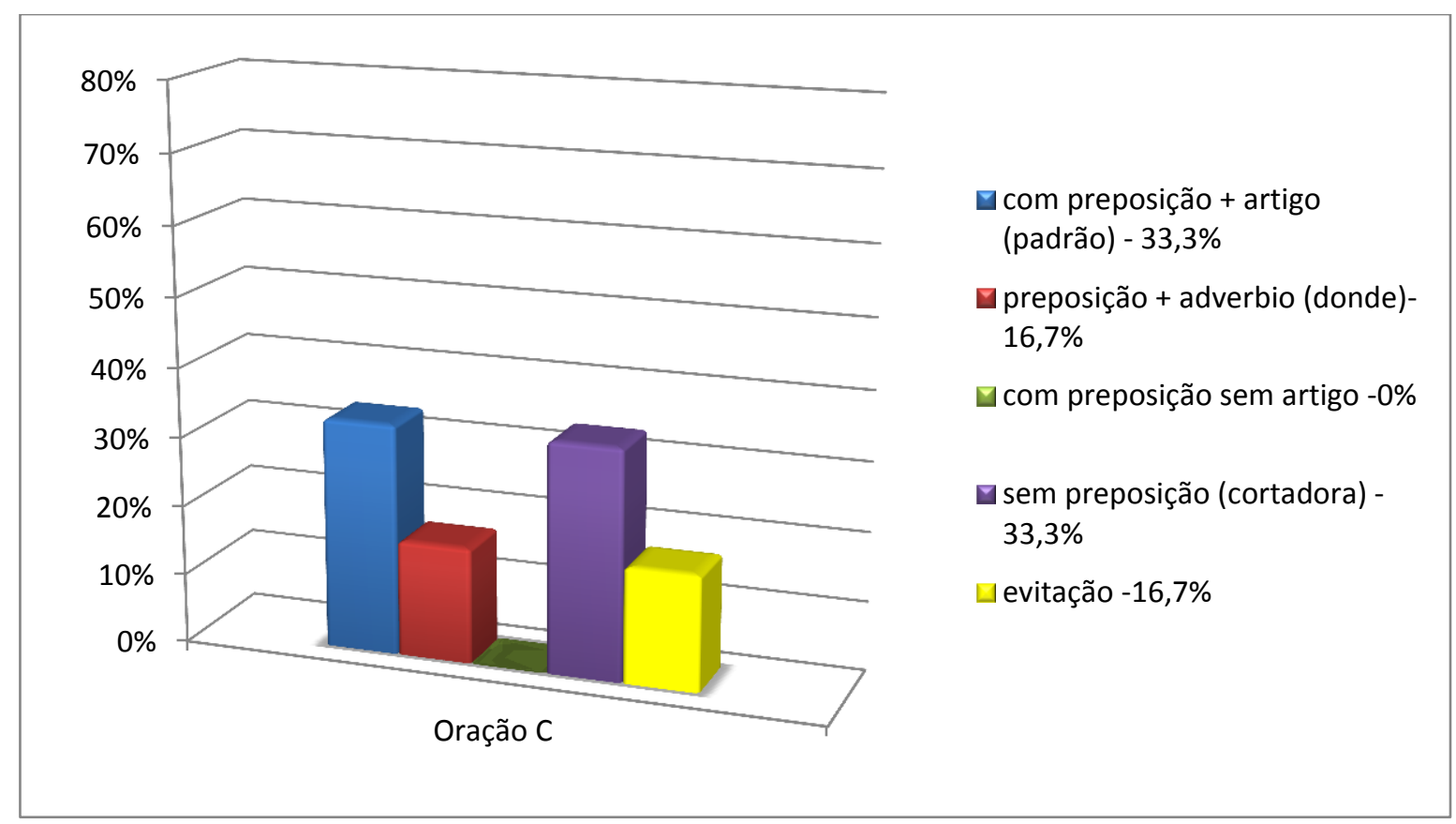

Gráfico 4 - Reformulações dos Hispanofalantes para oração C

Os hispanofalantes tiveram o mesmo índice de ocorrência para a reformulação padrão e para a cortadora (33,3\%). Pensamos assim que, neste caso, não há preferência por nenhuma das duas. Também observamos que $16,7 \%$ dos casos usaram a estrutura "prep. en + adv. donde", tipo de oração não realizada pelos estudantes brasileiros.

Devemos lembrar que essa sequência de "prep.+ adv." (em onde) não seria possível no PB. 
Mas diferentemente dos estudantes de ELE, houve casos de evitação (81) e, novamente, nenhum caso de reformulação com preposição e sem artigo, usada pelos estudantes brasileiros.

81. La empresa va a cerrar, es donde trabajo desde hace 10 años. (D, 29)

Comparando os dois gráficos para a oração C, vemos que novamente os estudantes brasileiros preferiram cortar o artigo e produzir orações com "prep. sem art." enquanto os nativos não as usaram em nenhum caso. Ao invés, usaram em igual número orações padrão com "prep. + art." e orações cortadoras.

A porcentagem de produção de orações com advérbio para brasileiros e nativos é bem próxima. E os nativos usaram a oração de evitação enquanto os brasileiros, não. 


\subsection{REFORMULAÇÕES DA ORAÇÃO D}

\section{Oração D:}

Mi mujer es linda. Estoy casado con ella hace 20 años.

\subsubsection{Gráfico das reformulações dos estudantes brasileiros de ELE}

Os informantes produziram os seguintes tipos de orações:

- Com preposição + artigo + que (padrão): La mujer con la que estoy casado hace 20 años es linda.

- Preposição + quien: La mujer con quien estoy casado hace 20 años es linda.

- Com preposição e sem artigo: La mujer con que estoy casado hace 20 años es muy linda.

- Sem preposição (cortadora): La mujer que me casé hace 20 años es linda.

Evitação: La mujer linda es mi esposa, con ella estoy casado hace 20 años. 


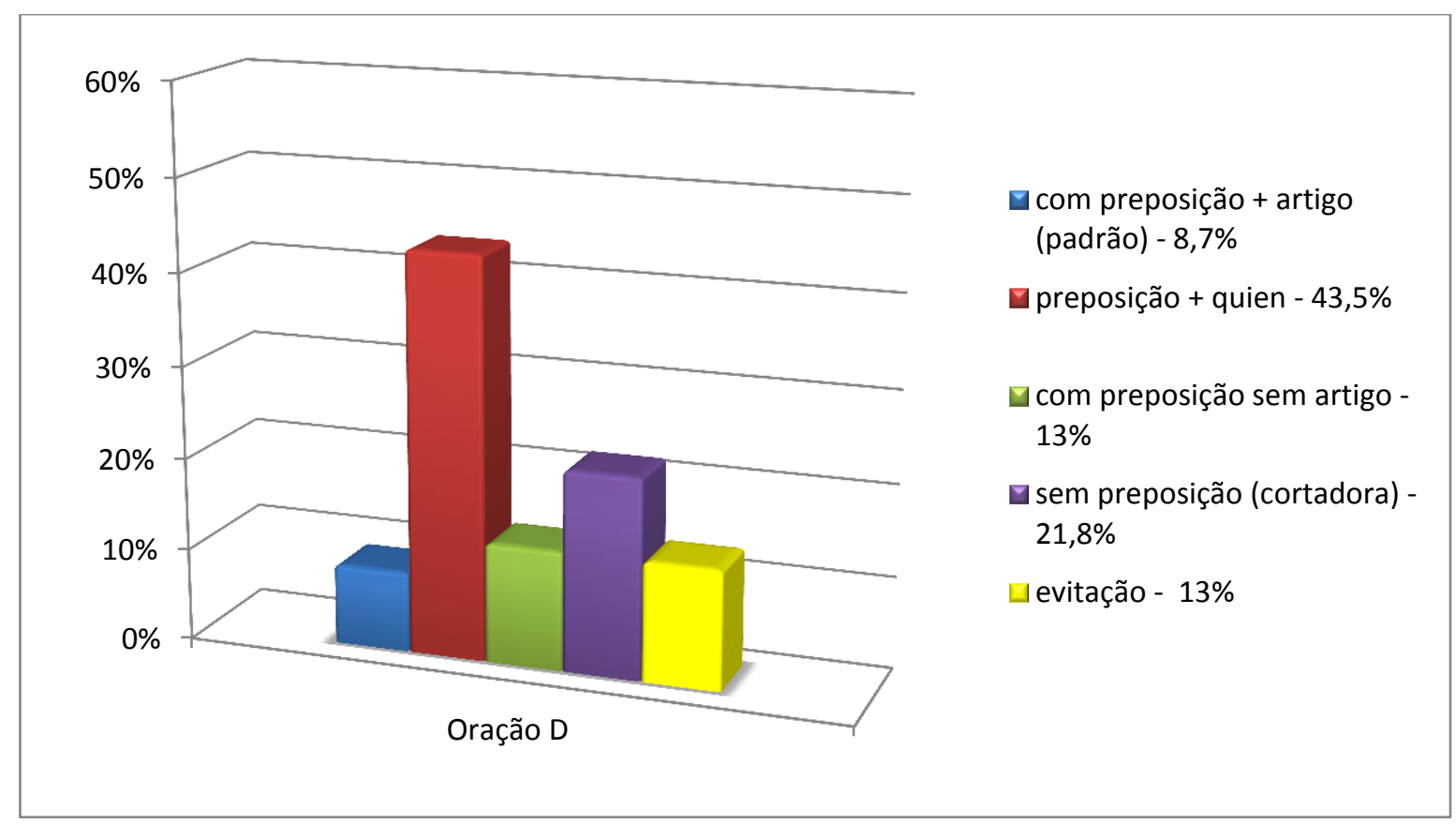

Gráfico 5 - Reformulações dos estudantes brasileiros de ELE para a oração D

A maioria dos informantes (43,5\%) usou a estrutura "prep. + quien" seguida pela ocorrência de cortadoras $(21,8 \%)$. A relativa padrão "prep. + art." foi a menos usada (8,7\%) e observamos que $13 \%$ dos informantes usaram alguma oração de evitação e "prep. sem art."

Quase a metade dos estudantes optou pela estrutura "prep. + quien" em detrimento da cortadora, o que difere dos dados de Kenedy (2008), que afirma que os brasileiros produziriam com maior frequência orações cortadoras do que preposicionadas, mesmo com antecedente [+humano] (ver cap. 2.2). 
A oração de "prep. sem art.", muito usada nas reformulações anteriores, teve baixo índice de ocorrência. O caráter [+ humano] do antecedente "mujer" levou os informantes a explicitarem essa animacidade com o relativo "quien" e diminuiu a realização das orações com o relativo "que".

A relativa padrão "prep. + art." foi novamente a opção menos usada pelos informantes brasileiros, o que, como já foi dito, era esperado.

\subsubsection{Gráfico das reformulações dos Hispanofalantes}

Os informantes produziram os seguintes tipos de orações:

- Com preposição + artigo + que (padrão): La mujer con la que estoy casado hace 20 años, es linda.

- Preposição + quien: La mujer con quien estoy casado hace 20 años es muy linda.

n Com preposição e sem artigo: não houve ocorrências.

- Sem preposição (cortadora): La mujer que estoy casado hace 20 años es muy linda.

Evitação: La mujer es linda, estoy casado con ella hace 20 años. 


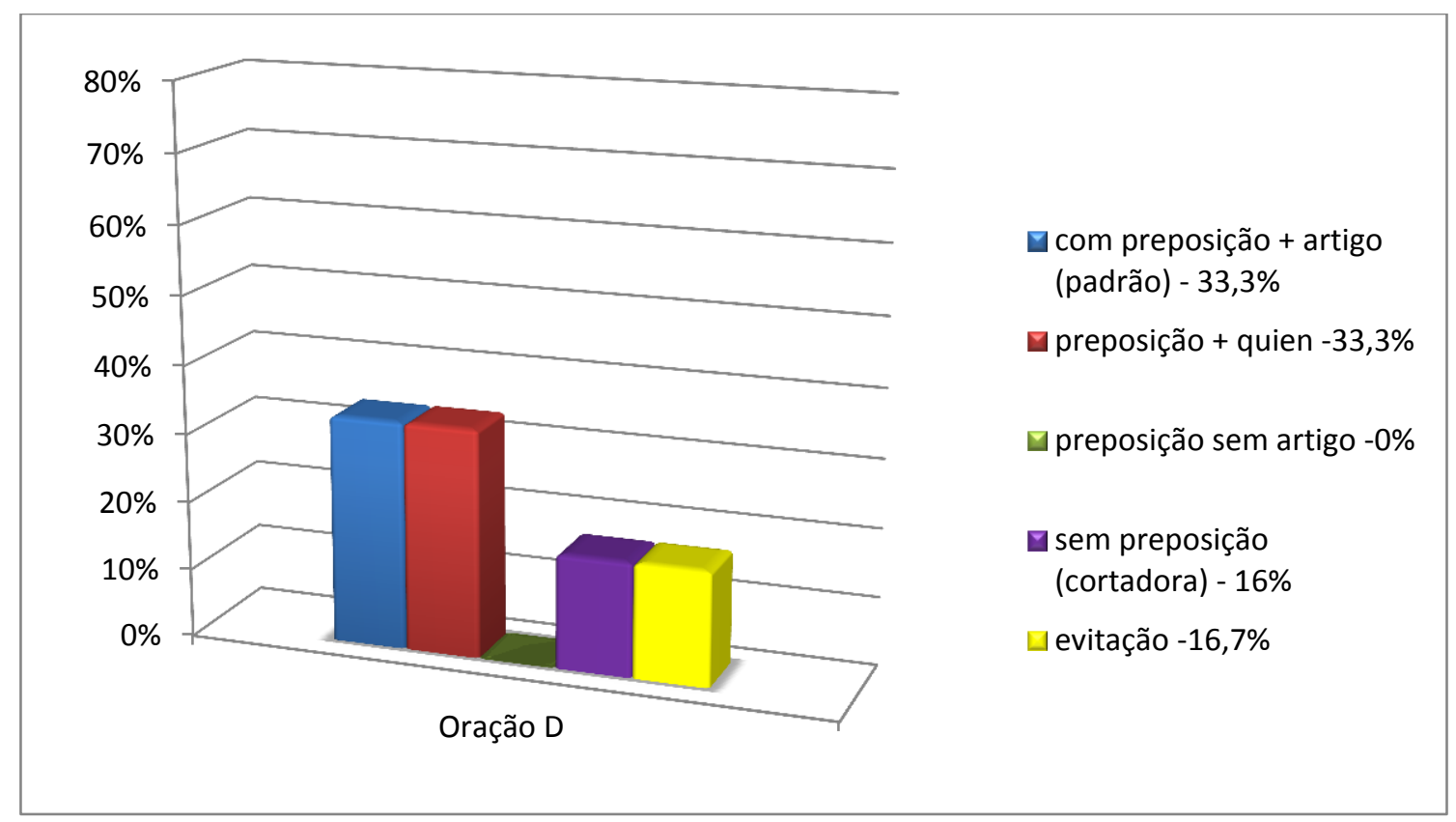

Gráfico 6 - Reformulações dos Hispanofalantes para a oração D

A maioria dos informantes produziu orações padrão, seja com "prep. + quien" ou "prep. + art." (con la que), É interessante observar que as duas opções ocorreram na mesma porcentagem (33,3\%). Podemos notar que não há preferência em relação a nenhuma das duas estruturas para esta reformulação. À diferença do que foi observado nos dados dos estudantes de ELE, que usaram, em uma porcentagem maior, o relativo "quien" (ver gráfico 4.3.1).

Mas como já dissemos anteriormente, já era o esperado, devido à dificuldade que apresentam os estudantes brasileiros com tais estruturas. 
Também houve índice de ocorrência igual das orações de evitação e relativas cortadoras $(16,7 \%)$, e novamente não houve nenhuma amostra de oração com preposição e sem artigo.

Comparando os dois gráficos para a oração $D$, novamente vemos o uso da opção com "prep. sem art." pelos estudantes brasileiros e a dificuldade que possuem com a realização da oração padrão "prep. + art.", já que preferiram a opção padrão com "quien" enquanto os nativos usaram as duas opções padrão na mesma porcentagem. 


\subsection{REFORMULAÇÕES DA ORAÇÃO E}

\section{Oração E:}

Este traje es azul. Con este traje Julio visitó a su abuela.

\subsubsection{Gráfico das reformulações dos estudantes brasileiros de ELE}

Os informantes produziram os seguintes tipos de orações:

- Com preposição + artigo + que (padrão): El traje con el que Julio visitó a su abuela es azul.

- Com preposição e sem artigo: El traje com que Julio visitó a su abuela es azul.

- Sem preposição (cortadora): El traje que Julio visito a su abuela es azul.

Evitação: El traje azul fue utilizado por Julio para visitar a su abuela. 


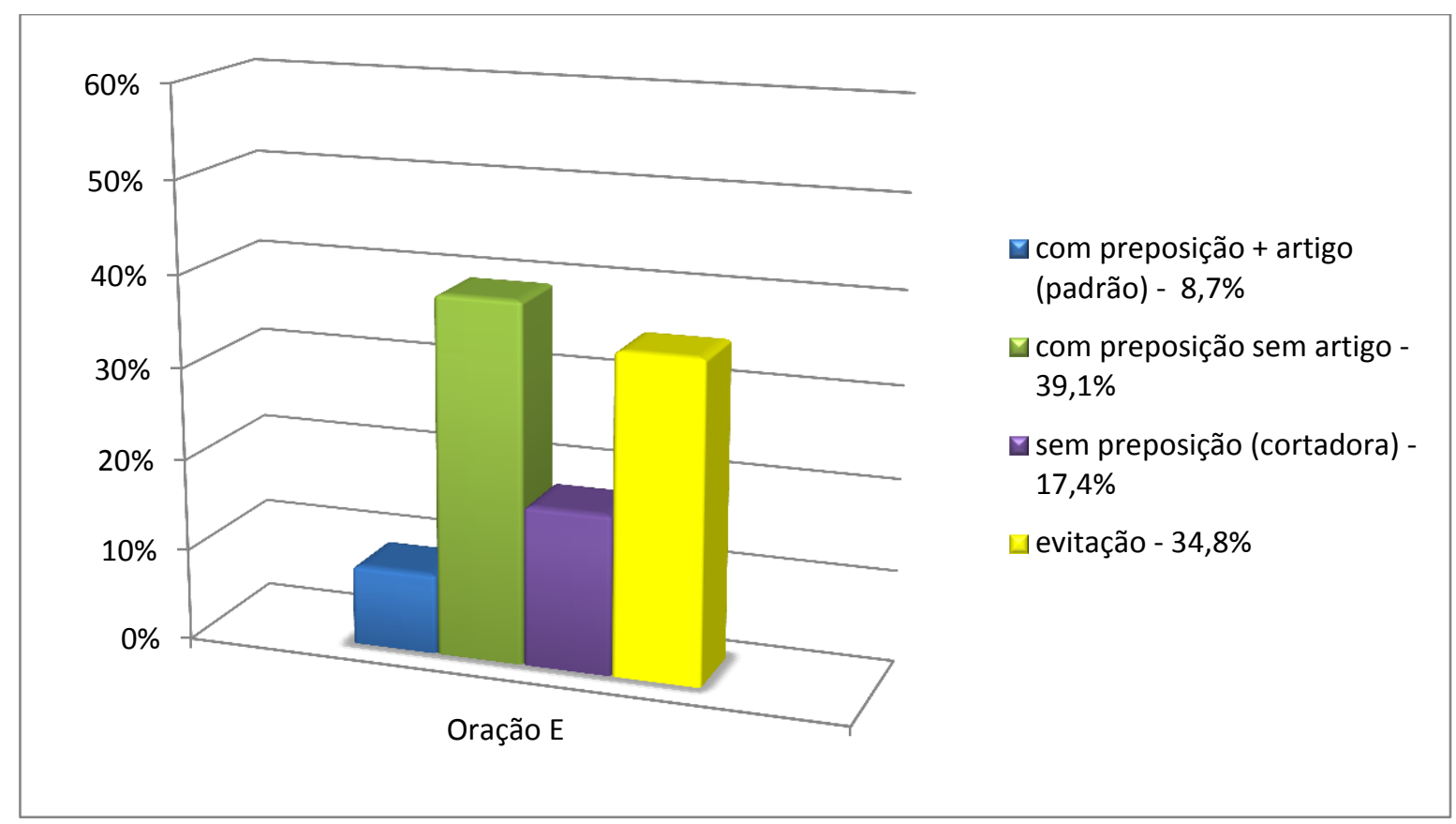

Gráfico 7 - Reformulações dos estudantes brasileiros de ELE para a oração E

Os dados dos estudantes brasileiros apresentam maior ocorrência de oração de "prep. sem art." e de evitação. Não houve ocorrências de "prep. + quien" já que temos um antecedente [- humano] (traje), e o pronome relativo "quien" possui traço [+ humano].

A menor ocorrência observada foi novamente referente à relativa "prep. + art.", mostrando uma dificuldade na realização de tal estrutura, o que já era esperado, como citado anteriormente.

Comparando as orações D e E vemos que, apesar de apresentarem estruturas com a mesma preposição (con), seus gráficos expressam um 
comportamento não uniforme na produção de ambas as reformulações pelos estudantes brasileiros.

É interessante recordar que o traço [+ humano] do antecedente da oração D (mujer) possibilitou o uso de "quien" em lugar de "prep.+ art. + que", ajudando os informantes a evitarem essa construção, com a qual não se sentem à vontade. O que não poderia ocorrer na oração E, pois o antecedente é [- humano] (traje).

Ainda com relação às orações padrão realizadas para a oração $E$, observamos os seguintes dados:

82. El traje con el que Julio visitó a su abuela es azul.

83. El traje con lo que Julio visito su abuela es azul.

Um informante usou o artigo neutro "lo" em lugar do artigo masculino "el", tornando a oração equivocada em relação à regra gramatical, já que "traje" é um substantivo masculino e "Io" não é artigo usado com substantivos. Porém, esse é um erro frequente em lusoparlantes estudantes de ELE, já que o artigo masculino e o neutro em PB têm a mesma forma ("o"), fazendo com que os lusoparlantes não diferenciem, de imediato, o caráter neutro do "lo". ${ }^{19}$

\footnotetext{
${ }^{19}$ Devido aos limites deste trabalho, não nos estenderemos a tratar sobre o artigo neutro "Io".
} 


\subsubsection{Gráfico das reformulações dos Hispanofalantes}

Os informantes produziram os seguintes tipos de orações:

- Com preposição + artigo + que (padrão): El traje con el que Juan visito a su abuela es azul.

- Com preposição e sem artigo: não houve ocorrências.

- Sem preposição (cortadora): não houve ocorrências.

Evitação: El traje es azul, con él Julio visitó a su abuela.

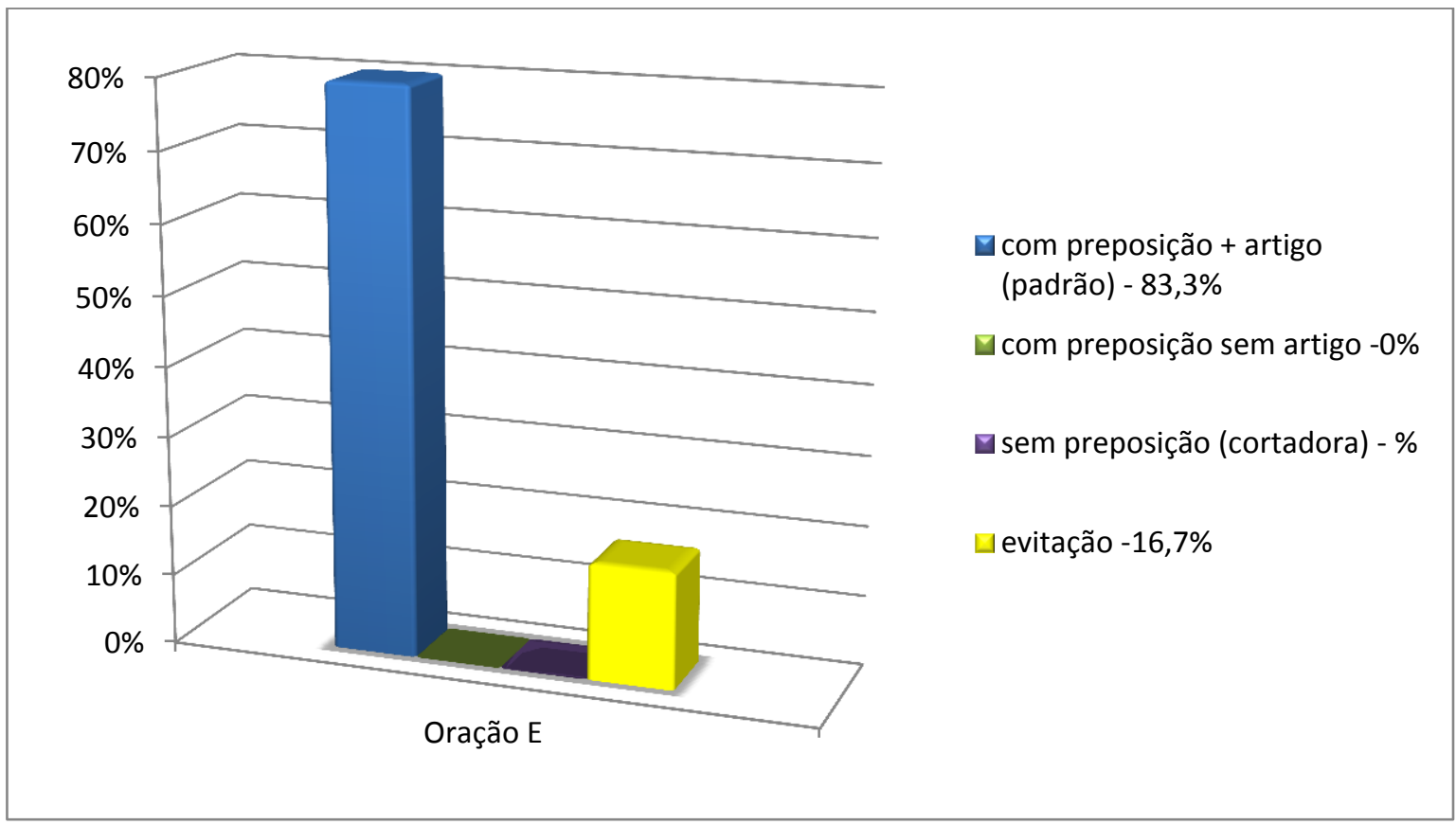

Gráfico 8 - Reformulações dos Hispanofalantes para a oração E 
Em relação às reformulações dos hispanofalantes, observamos algo interessante: uma alta incidência (83,3\%) de relativa padrão (84), o que difere das amostras dos estudantes brasileiros, onde a maior incidência foi de "prep. sem artigo", como visto anteriormente.

84. El traje con el que Julio visito a su abuela es azul.

Está clara a preferência, nesta reformulação, pela oração padrão com artigo e preposição. Os informantes não realizaram a cortadora, tampouco a "prep. sem art.", que até o momento não foi verificada em nenhuma reformulação de hispanofalantes, embora, segundo Brucart (1999), o artigo definido possa ser suprimido em orações relativas com algumas preposições como "a", "con", "de", "en" e "por". ${ }^{20}$

Chamou-nos a atenção a inexistência de reformulações cortadoras, que costumam ser produzidas com frequência no $E$, segundo Suñer (2001) ${ }^{21}$

Comparando os dois gráficos da oração $\mathrm{E}$, observamos que os nativos preferiram a opção padrão enquanto os estudantes brasileiros as usaram em uma minoria das reformulações e preferiram cortar o artigo realizando orações com

\footnotetext{
${ }^{20}$ Ver subcap. 2.1.4 e 2.1.5 deste trabalho.

${ }^{21}$ Ver subcap. 2.5.1 deste trabalho.
} 
"prep. sem art.". Não houve registro de cortadoras nos dados dos nativos e nos dados dos brasileiros apareceram em $17,4 \%$ das reformulações. Sobre as orações de evitação, os nativos as usaram em uma minoria das reformulações $(16,7 \%)$ enquanto os estudantes brasileiros as usaram em $34,8 \%$ das orações.

Não há uma uniformidade nas orações de evitação que nos permita chegar a alguma conclusão sobre seu uso. 


\subsection{REFORMULAÇÕES DA ORAÇÃO F}

\section{Oração F:}

La casa era muy grande. Yo viví allí.

\subsubsection{Gráfico das reformulações dos estudantes brasileiros de ELE}

Os informantes produziram os seguintes tipos de orações:

- Com preposição + artigo + que (padrão): não houve ocorrências.

- Advérbio donde sem preposição: La casa donde viví era muy grande.

- Com preposição e sem artigo: La casa em que viví era muy grande.

- Sem preposição (cortadora): La casa que yo viví era muy grande. Evitação: não houve ocorrências. 


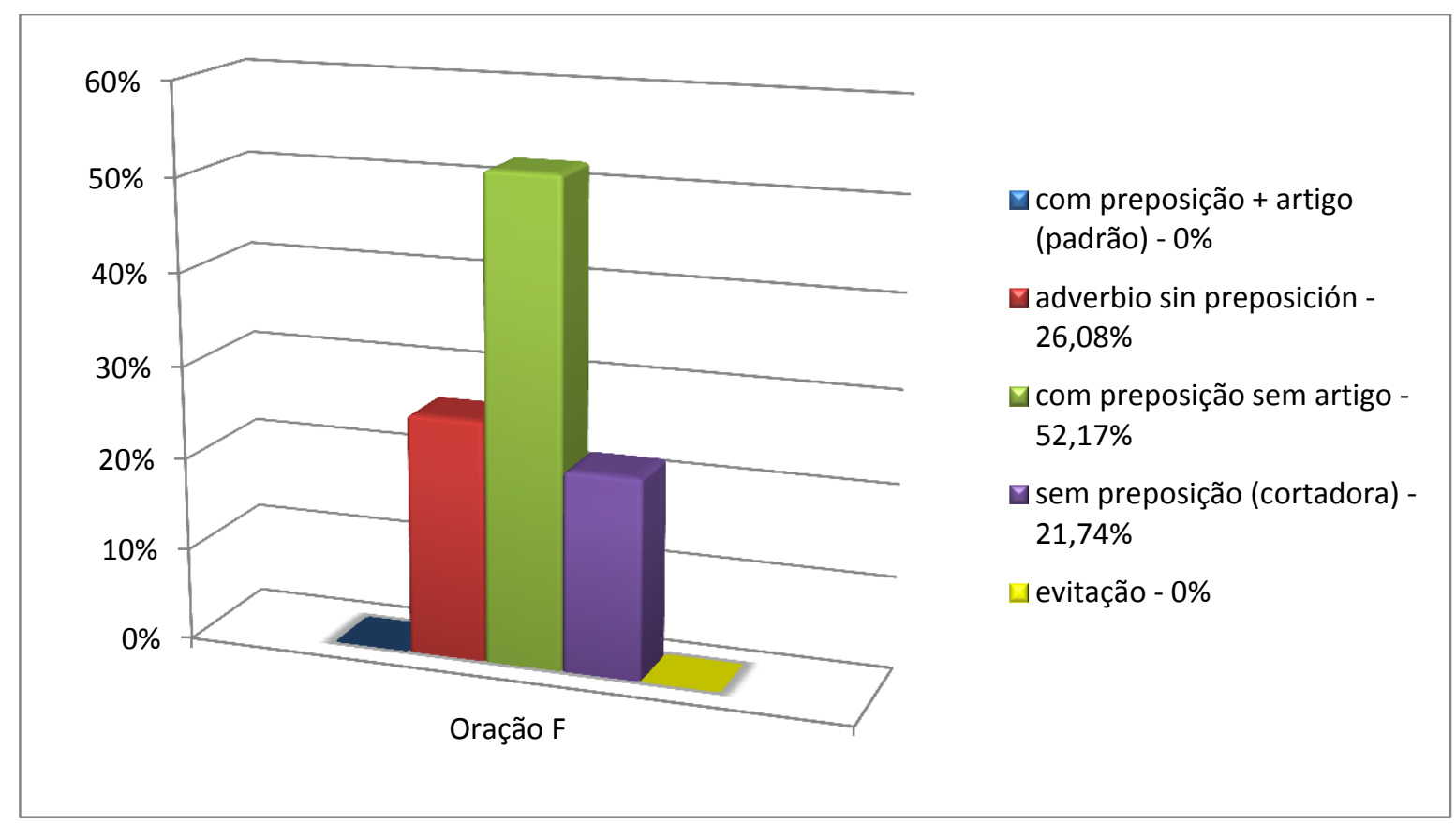

Gráfico 9 - Reformulações dos estudantes brasileiros de ELE para a oração F

Novamente os estudantes de ELE usaram a oração "prep. sem art." com maior frequência $(52,17 \%)$, seguida pelas orações "adv. (donde) sem prep." $(28,08 \%)$ e cortadora $(21,74)$.

Como ocorreu com as outras reformulações dos estudantes de ELE, houve maior incidência de orações de "prep. sem art." que de cortadoras.

Esperávamos que a primeira opção fosse produzir uma oração cortadora, mas os informantes se sentiram mais à vontade cortando o artigo, que se refere ao caráter definido do substantivo. O que nos mostra que, para os estudantes 
brasileiros, o artigo pode ser suprimido sem que se prejudique esse caráter definido.

Não observamos amostras de relativa padrão (85) ou evitação.

85. La casa en la que viví era muy grande.

Devido ao caráter locativo da oração, foi possível usar o advérbio donde, mantendo uma relativa padrão e evitando o uso de "prep. + art.", que, como já citado anteriormente (PERRONI, 2001), constitui uma estrutura de difícil aquisição para o falante de PB em sua língua materna ${ }^{22}$.

\subsubsection{Gráfico das reformulações dos Hispanofalantes}

Os informantes produziram os seguintes tipos de orações:

- Com preposição + artigo + que (padrão): La casa en la que yo viví, era muy grande.

\footnotetext{
${ }^{22}$ Ver subcap. 2.2.1 e 2.2.2.
} 
- Preposição + advérbio donde: La casa en donde yo viví allí es muy grande.

- Com preposição e sem artigo: La casa en que yo viví allí es muy grande.

Sem preposição (cortadora): não houve ocorrências.

Evitação: La casa era muy grande, yo viví allí

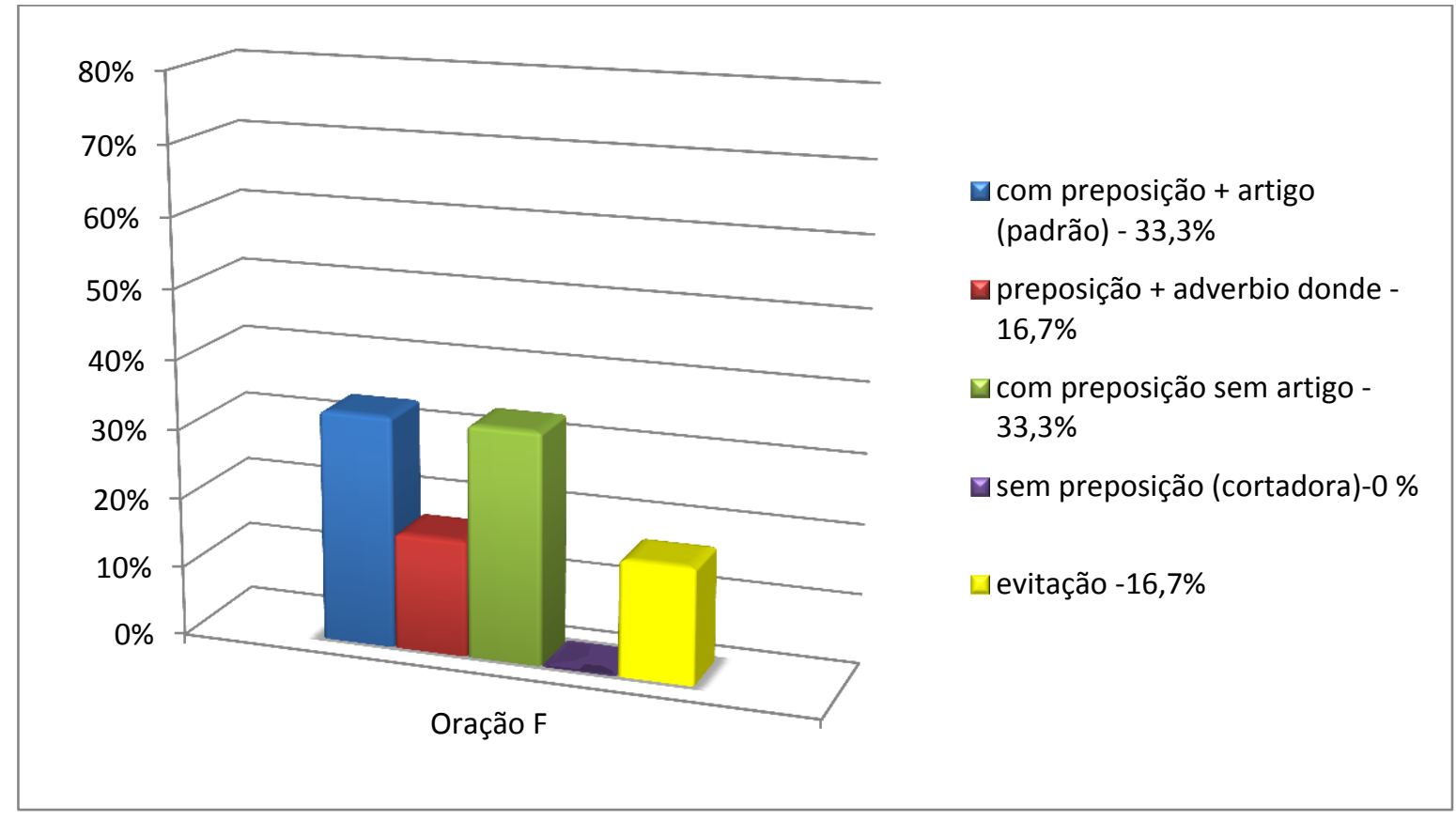

Gráfico 10 - Reformulações dos Hispanofalantes para a oração F

Já no gráfico dos hispanofalantes, observamos que as construções mais frequentes possuem a preposição "en" ("prep. +art." e "prep. sem art."). 
Enquanto os estudantes de ELE usaram quase unicamente a opção sem o artigo (86), os hispanofalantes usaram na mesma proporção a oração padrão "prep. + art." (87) e a oração sem o artigo (88). Não houve a opção de relativa cortadora, e as orações de evitação (89) aparecem em 16,7\% das amostras.

86. La casa en que yo vivía era muy grande.

87. La casa en la que yo viví, era muy grande.

88. La casa en que yo viví allí es muy grande.

89. La casa era muy grande, yo viví allí

Chamou-nos a atenção a realização, pela primeira vez em nosso corpus, da oração "prep. sem art." por informantes nativos.

Comparando os dados da oração $F(90 a$ e $90 \mathrm{~b})$ aos dados da oração $E$ (91), ambos também de nativos, anteriormente analisados. Novamente as duas orações possuem estruturas semelhantes, mas nos fornecem dados diferentes.

90. a. La casa en que yo viví allí es muy grande. (Oração F) b. La casa en la que yo viví, era muy grande. (Oração F) 91. El traje con el que Juan visitó a su abuela es azul. (Oração E)

Sabemos que orações locativas permitem o corte de preposição tanto em E (SUÑER, 2001) quanto em PB (TARALLO, 1983). A oração F é locativa, mas a 
E não pode ser interpretada da mesma maneira, assim, os informantes nativos não realizaram corte de preposição nos dados de reformulação de $\mathrm{E}$.

Também podemos fazer uma comparação das orações $F(92)$ e $C(93)$. As duas são estruturas locativas com a mesma preposição (en), mas a interpretação dos dois substantivos (casa e empresa) pode ser diferente. A interpretação semântica de "casa", no enunciado, é a de um lugar físico, enquanto a de "empresa", além de lugar físico, também pode aludir à "instituição", que remete a caráter [+ humano].

92. La casa en que yo viví allí es muy grande.

93. La empresa en la que trabajo hace 10 años, va a cerrar.

Brucart (1999) diz que antecedentes como os de modo, maneira e forma tendem a requerer a construção sem artigo, mas a oração $\mathrm{F}$ não se encaixa em nenhuma das três opções. Portanto, pensamos que estas diferentes interpretações dos substantivos possibilitou ao informante nativo omitir o artigo definido em (92), já que o caráter definido está intrínseco semanticamente.

Comparando, por último, os gráficos produzidos para a oração $F$, observamos novamente a preferência pela opção "prep. sem art.", a não ocorrência de oração padrão "prep. + art." ou evitações no gráfico dos estudantes 
brasileiros e a não ocorrência, novamente, de orações cortadoras no gráfico dos nativos, embora as orações locativas permitam o corte da preposição. 


\subsection{REFORMULAÇÕES DA ORAÇÃO G}

\section{Oração G:}

Hablábamos de una mujer. Esa mujer no era Juana.

\subsubsection{Gráfico das reformulações dos estudantes brasileiros de ELE}

Os informantes produziram os seguintes tipos de orações:

- Com preposição + artigo + que (padrão): La mujer de la que hablábamos no era Juana.

- Preposição + quien: La mujer de quien hablábamos no era Juana / La mujer sobre quien hablábamos no era Juana.

- Com preposição e sem artigo: La mujer de que hablábamos no era Juana

- Sem preposição (cortadora): La mujer que hablábamos no era Juana.

Evitação: La mujer no es Juana. Hablábamos de otra persona. 


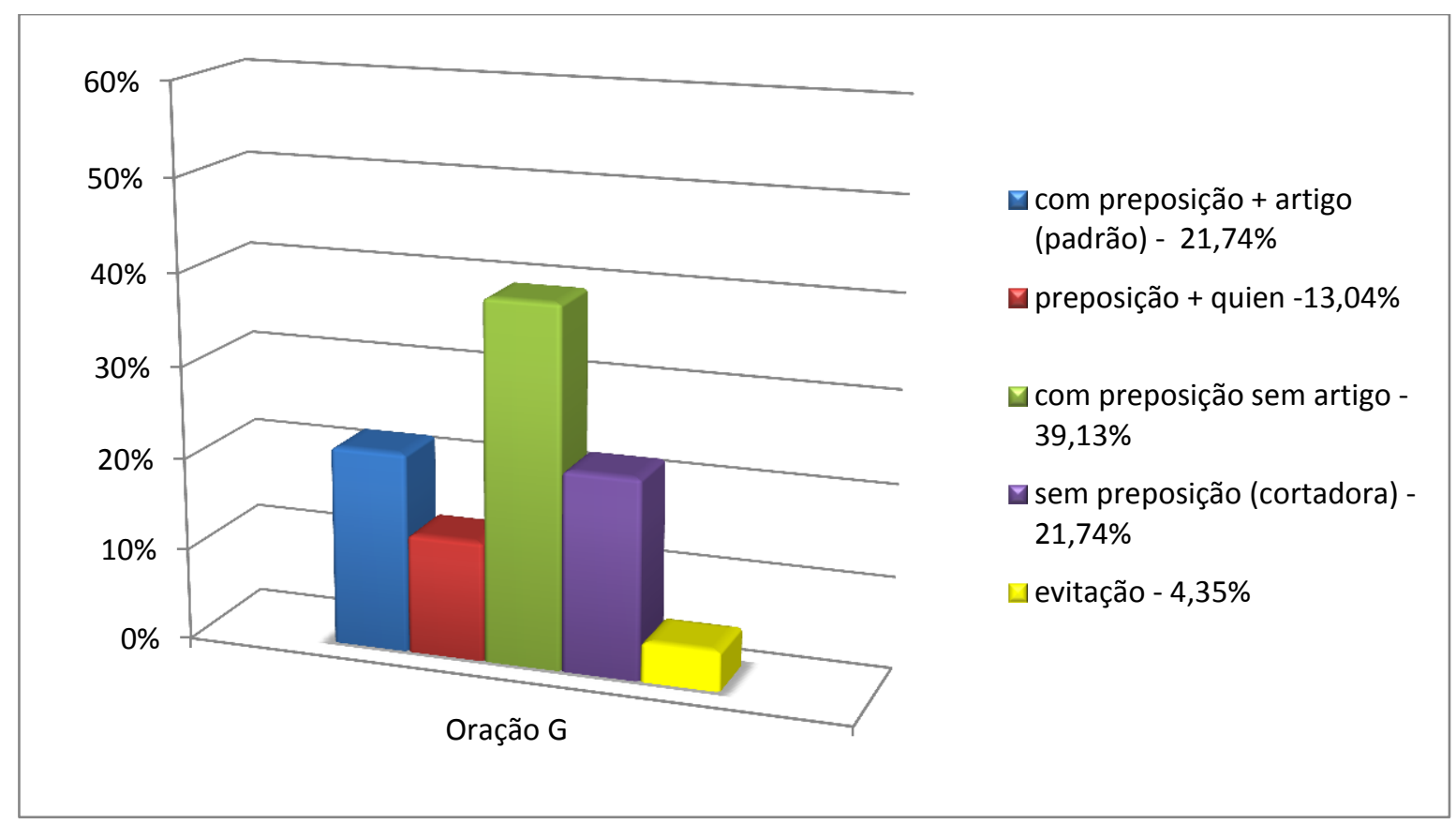

Gráfico 11 - Reformulações dos estudantes brasileiros de ELE para a oração G

Observamos, novamente, o maior índice de reformulações usando a oração "prep. sem art." (39,13\%), seguida pelas orações relativa padrão "prep. + art." e cortadora $(21,74 \%)$. Os tipos de orações menos usadas foram a "prep.+ quien" (13,04\%) e evitação $(4,35 \%)$.

Não houve preferência pelo uso da oração padrão "prep. + que" (94) ou pela cortadora (95), mas entre as orações padrão, a opção com "quien" (96) foi a menos usada.

94. La mujer de la que hablábamos no era Juana.

95. La mujer que hablábamos no era Juana. 
96. La mujer de quien hablábamos no era Juana

Quando comparamos a oração $G(97)$ à oração $D(98)$ notamos que são semelhantes quanto à gramática. Mas os dados dos estudantes brasileiros para a oração $G$ nos mostram um comportamento inverso ao analisado na oração $D$ para as estruturas padrão. Na D há preferência pela oração padrão com "quien" em detrimento da padrão com "que", o contrário do que ocorre para a G.

97. La mujer con quien estoy casado hace 20 años es linda.

98. La mujer de la que hablábamos no era Juana.

O aparecimento da cortadora (95) em $21,74 \%$ das orações pode estar relacionado ao fato de, segundo Tarallo (1983), o verbo "falar", em PB, ser um dos listados pelo autor como "frequente" em orações cortadoras ${ }^{23}$. O verbo "casar-se" não faz parte da lista de verbos que apareceram com orações cortadoras no trabalho do autor, portanto, concluímos que o verbo "hablar" contribuiu para o corte da preposição pelos estudantes brasileiros.

\footnotetext{
${ }^{23}$ Ver lista de verbos que apareceram com cortadoras no PB, segundo Tarallo (1983, p. 227)
} 


\subsubsection{Gráfico das reformulações dos Hispanofalantes}

Os informantes produziram os seguintes tipos de orações:

- Com preposição + artigo + que (padrão): La mujer de la que hablábamos, no era Juana.

- Preposição + quien: La mujer con quien hablamos no era Juana / La mujer de quien hablamos no era Juana.

- Com preposição e sem artigo: La mujer de que hablamos no era Juana.

- Sem preposição (cortadora): não houve ocorrências.

Evitação: não houve ocorrências. 


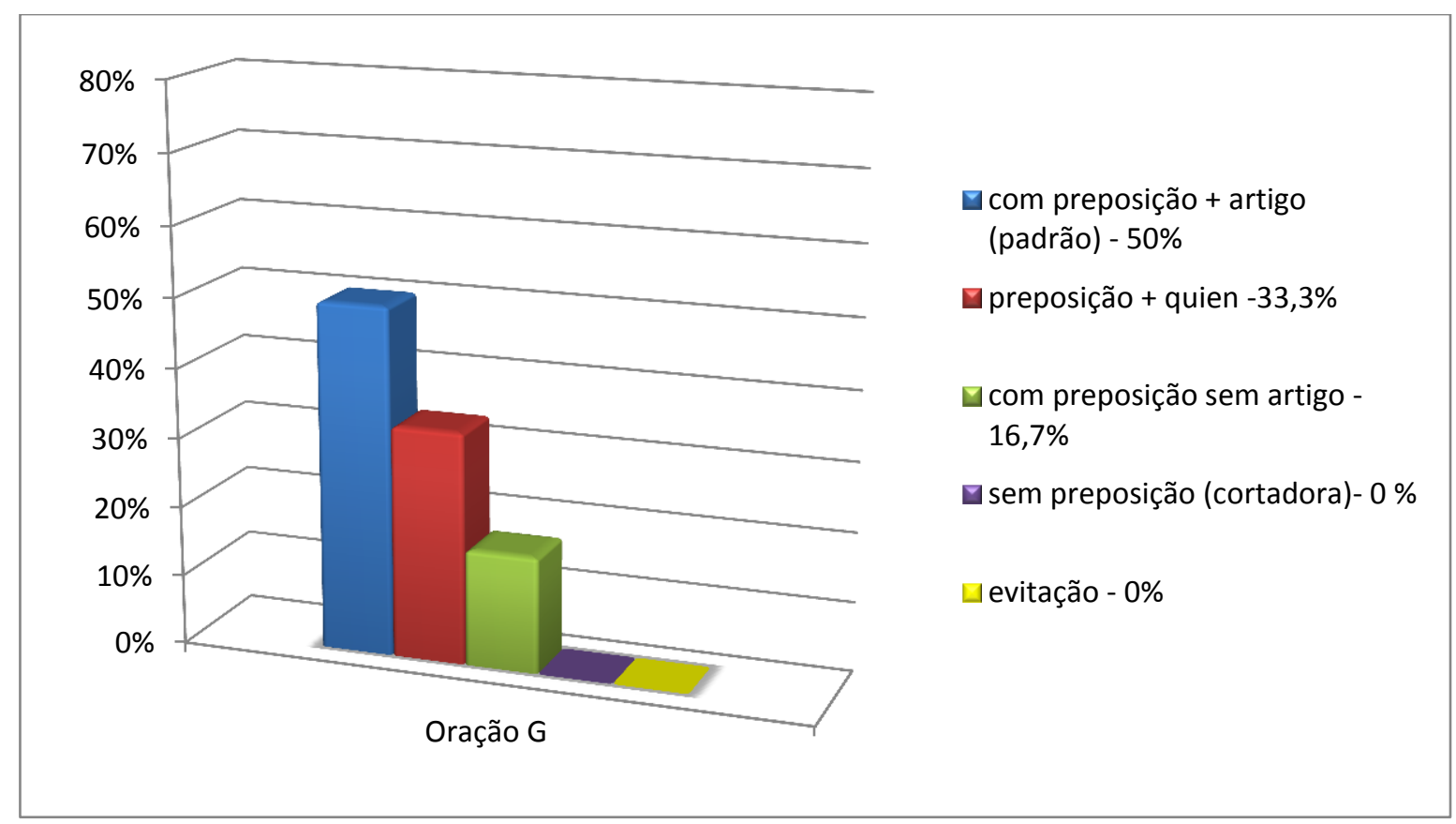

Gráfico 12 - Reformulações dos Hispanofalantes para a oração G

Mais uma vez houve uma grande incidência de amostras com preposição. Desta vez a preferência foi pela relativa padrão com "prep. + art." seguida pela padrão "prep. + quien". Não houve nenhuma incidência de relativa cortadora ou de evitações.

À diferença dos dados dos estudantes brasileiros, onde os informantes utilizaram a oração cortadora em mais de $20 \%$ das reformulações, os dados dos nativos não apresentaram tais estruturas. É interessante ressaltar que as características do verbo "hablar" em E não propiciaram o corte da preposição pelos nativos, como ocorreu com os estudantes brasileiros. 
Para esta reformulação, os nativos produziram orações com "prep. sem art." (16,7\%), mas não com a frequência dos estudantes brasileiros $(39,13 \%)$, que vêm apresentando grande quantidade de produções deste tipo na análise deste corpus.

Comparando os dois gráficos para a oração $G$, observamos a não ocorrência de orações cortadoras para os dados dos nativos, e $21,4 \%$ de frequência destas orações nos dados dos estudantes brasileiros. Essa frequência pode estar relacionada às características do verbo "falar" em PB que está listado por Tarallo (1983) como um dos verbos que aparecem com orações cortadoras, mas podemos observar que o mesmo não ocorre para o verbo "hablar" em $\mathrm{E}$, para os nativos.

Observamos também que os estudantes brasileiros novamente preferiram a opção "prep. sem art." enquanto os nativos usaram com mais frequência a padrão "prep. + art.". Apenas um informante nativo preferiu não retomar o caráter definido do antecedente "mujer" com o artigo definido "la" ou o pronome relativo "quien". 


\subsection{REFORMULAÇÕES DA ORAÇÃO H}

\section{Oração H:}

La niña usa gafas. A ella le di un helado

\subsubsection{Gráfico das reformulações dos estudantes brasileiros de ELE}

Os informantes produziram os seguintes tipos de orações:

- Com preposição + artigo + que (padrão): La niña a la que le di un helado usa gafas.

- Preposição + quien: La niña, a quien di un helado, usa gafas.

- Com preposição e sem artigo: não houve ocorrências.

- Sem preposição (cortadora): La niña que le di un helado usa gafas.

Evitação: La niña usa gafas, entonces le di un helado. 


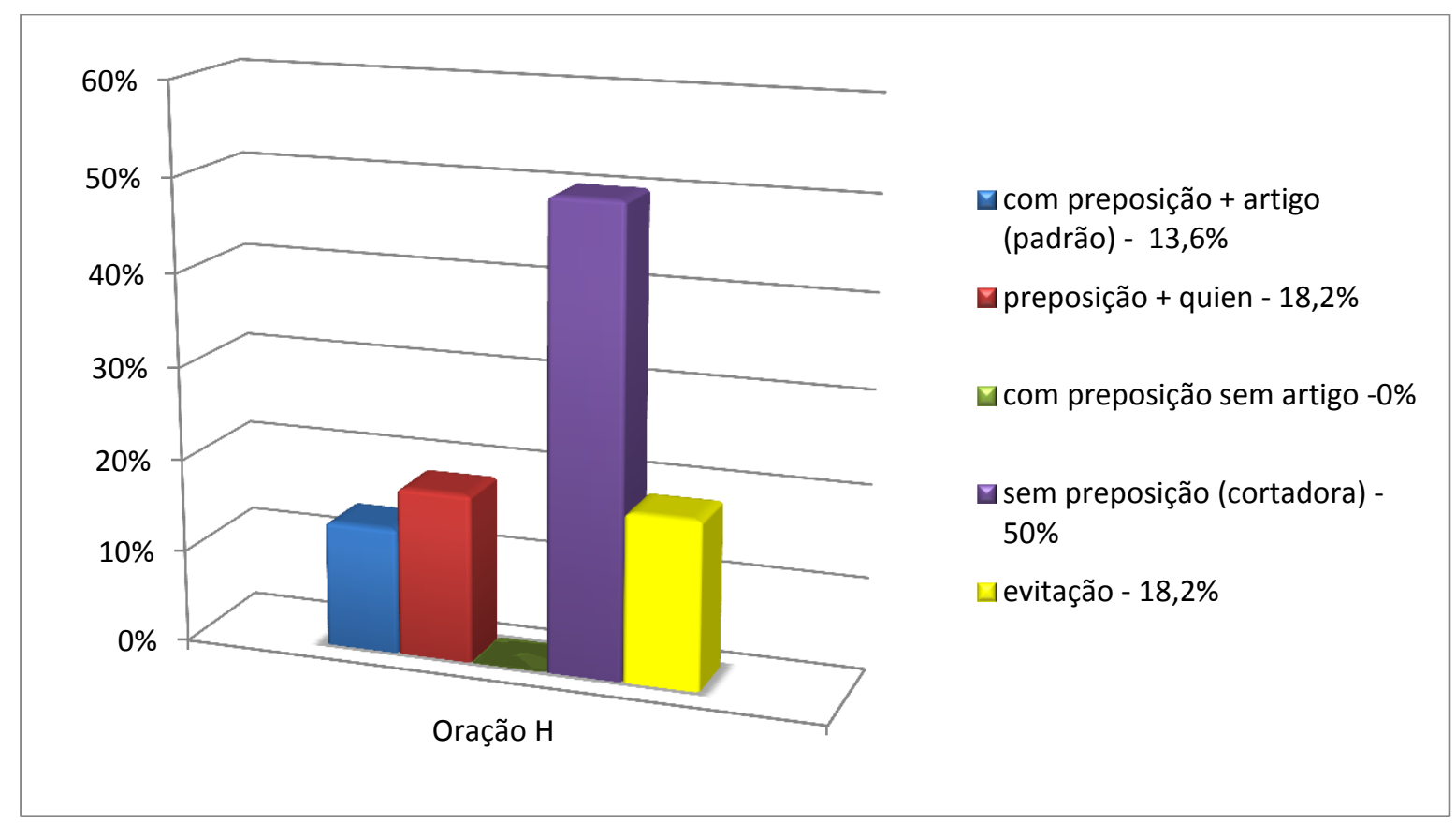

Gráfico 13 - Reformulações dos estudantes brasileiros de ELE para a oração H

Para a análise dos dados dos estudantes brasileiros para a oração $\mathrm{H}, \mathrm{a}$ totalidade de amostras teve que ser diminuída em uma porque um dos informantes do grupo B realizou uma oração (99) que não conseguimos encaixar em nenhum dos grupos analisados.

99. La niña al quien le di un helado usa gafas.

O informante produziu uma estrutura de prep.+ art. + quien. Houve um erro gramatical, já que o relativo "quien" não pode aparecer acompanhado de artigo, por já possuir um caráter definido. 
Sobre as amostras válidas para análise, metade dos informantes usou a oração cortadora para a reformulação e não houve amostras de "prep. sem art.", o que é interessante, já que essa opção foi produzida na maioria das orações de estudantes brasileiros analisadas até o momento.

O alto índice de cortadoras pode ser explicado, novamente, pela presença do verbo "dar", que também pertence à lista de Tarallo (1983) referente aos verbos presentes em orações cortadoras no PB. Chama-nos a atenção que a preferência pelo uso da cortadora impossibilitou a realização da oração com "prep. sem art.", tão usada pelos estudantes brasileiros em nosso corpus.

Em relação às orações padrão (com "quien" e "prep. + art.), a preferência foi pelo uso da oração com "quien", como ocorreu com os dados da oração D, também para os estudantes brasileiros, mostrados anteriormente.

Em comparação aos dados de estudantes brasileiros para a oração $G$, que também possui antecedente [+ humano] (mujer), vemos que os dados não são uniformes, pois houve preferência pela padrão com "que" em detrimento da padrão com "quien”. 


\subsubsection{Gráfico das reformulações dos Hispanofalantes}

Os informantes produziram os seguintes tipos de orações:

- Com preposição + artigo + que (padrão): La niña a la que le di un helado, usa gafas.

- Preposição + quien: La niña a quien le di un helado usa gafas.

- Com preposição e sem artigo: não houve ocorrências.

- Sem preposição (cortadora): La niña que le di un helado usa gafas.

Evitação: não houve ocorrências.

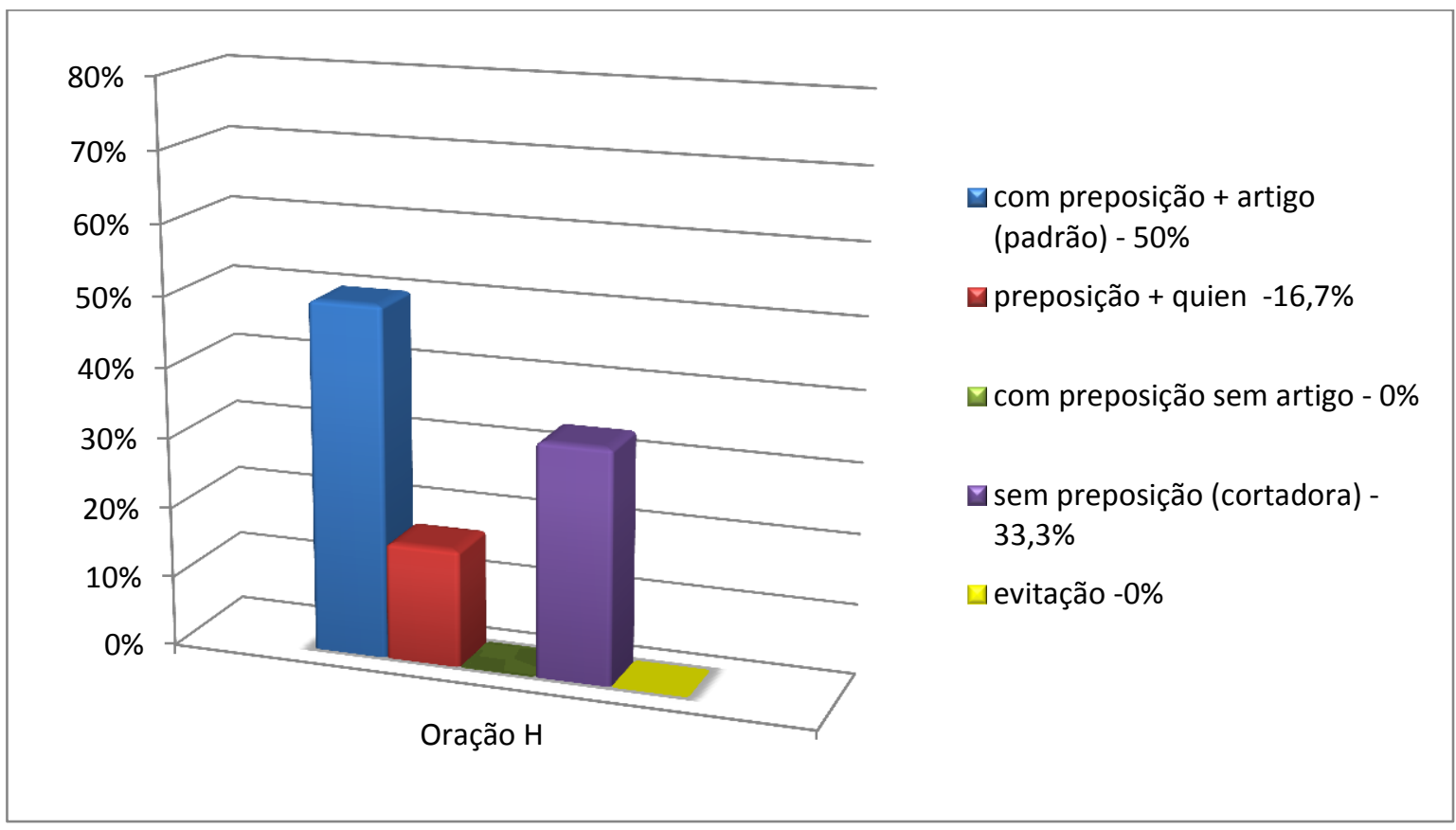

Gráfico 14 - Reformulações dos Hispanofalantes para a oração H 
A oração mais produzida foi a padrão com "que" (50\%), seguida pela cortadora $(33,3 \%)$ e, com maior distância, pela padrão com "quien" $(16,7 \%)$.

À diferença dos estudantes brasileiros, que produziram a padrão com "que" com baixa frequência, devido, como dito anteriormente, à dificuldade que apresentam os falantes de PB com a aquisição de tal estrutura. (PERRONI, 2001)

Não foi observado, como já havia ocorrido anteriormente, o uso das orações "prep. sem art.".

Comparando os dois gráficos da oração $\mathrm{H}$, vemos que os dados obtidos a partir da reformulação dos hispanofalantes são, mais uma vez, consideravelmente diferentes dos dados dos estudantes brasileiros. Mas pela primeira vez, nenhum dos dois grupos de informantes produziu orações com "prep. sem art.".

Novamente os nativos apresentaram maior uso da estrutura padrão com "que", mas os dois grupos tiveram índices próximos de uso da estrutura padrão com "quem". Os grupos diferiram quanto ao uso das evitações, que não foram produzidas pelos nativos, mas houve um índice de $18,2 \%$ no gráfico dos estudantes brasileiros. 


\subsection{REFORMULAÇÕES DA ORAÇÃO I}

\section{Oração I:}

Con aquella tableta había escrito algunas de mis novelas. Le regalé la tableta a Luís.

\subsubsection{Gráfico das reformulações dos estudantes brasileiros de ELE}

Os informantes produziram os seguintes tipos de orações:

- Com preposição + artigo + que/cual (padrão): Le regalé a Luis la tableta con la cual yo había escrito algunas de mis novelas / Le regalé a Luis la tableta con la que había escrito algunas de mis novelas.

- Advérbio onde ${ }^{24}$ sem preposição: Le regalé a Luis una tableta onde había escrito algunas de mis novelas.

- Com preposição e sem artigo: Le regalé a Luis la tableta con que había escrito algunas de mis novelas / Le regalé a Luis la tableta en que había escrito algunas de mis novelas.

\footnotetext{
${ }^{24}$ Uso equivocado de vocabulário em Português: advérbio "onde" em lugar de "donde".
} 
Sem preposição (cortadora): Le regalé a Luis la tableta que había escrito algunas de mis novelas.

Evitação: Le regalé a Luis la tableta con algunas de mis novelas escritas.

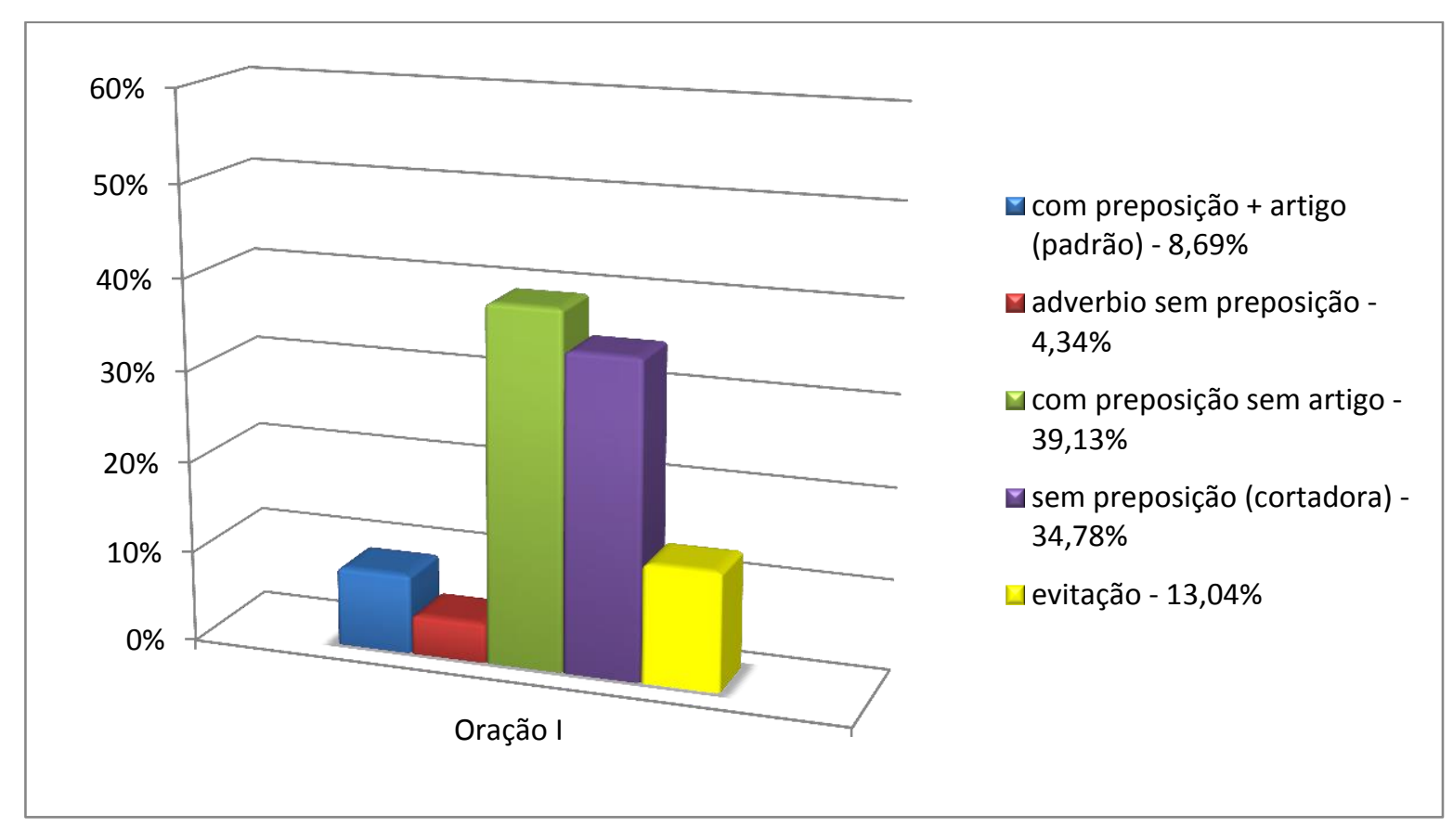

Gráfico 15 - Reformulações dos estudantes brasileiros de ELE para a oração I

Observamos apenas uma reformulação com o advérbio, mas a oração foi formulada equivocadamente, com o advérbio em português (onde) ao invés do advérbio em espanhol (donde):

100. Le regalé a Luis una tableta onde había escrito algunas de mis novelas. 
A maioria dos informantes optou, novamente, por realizar a oração "prep. sem art." (39,13\%), seguida de perto pela cortadora $(34,78 \%)$. Uma minoria realizou a oração padrão com "prep. + art." (8,69\%), o que já era esperado devido aos resultados das análises dos gráficos anteriores.

Quase não há diferença entre a ocorrência de oração cortadora (34,78\%) e "prep. sem artigo" (39,13\%), que são as duas opções mais frequentes nos dados dos estudantes brasileiros, devido ao fato, como dito anteriormente, da dificuldade desses informantes com a relativa padrão em sua própria língua materna.

\subsubsection{Gráfico das reformulações dos Hispanofalantes}

Os informantes produziram os seguintes tipos de orações:

- Com preposição + artigo + que (padrão): Le regalé a Luís, la tableta con la que escribí algunas de mis novelas.

- Preposição + advérbio: não houve ocorrências.

- Com preposição e sem artigo: Le regalé a Luís la tableta con que escribí algunas de mis novelas. 
Sem preposição (cortadora): não houve ocorrências.

Evitação: não houve ocorrências.

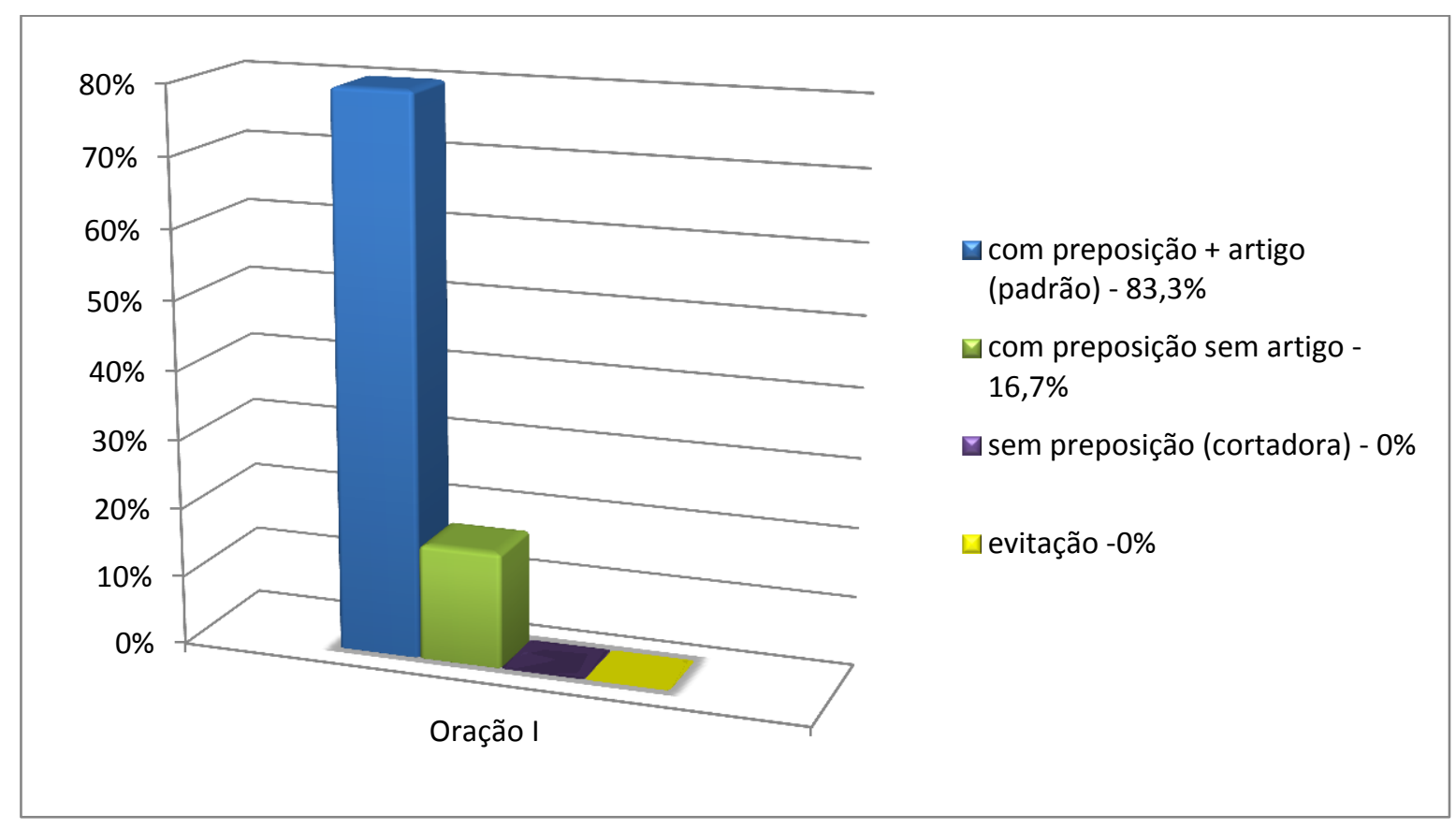

Gráfico 16 - Reformulações dos Hispanofalantes para a oração I

Este gráfico é bastante interessante, pois houve apenas amostras de dois tipos de oração: oração padrão "prep. + art." (83,3\%) e oração "prep. sem art." (16,7\%), com evidente preferência da oração padrão.

Chama-nos a atenção a uniformidade das produções, o que nos mostra que não há dúvida quanto ao uso da oração padrão para esta reformulação. Não houve amostras de cortadora, tampouco de evitação. 
Podemos afirmar que com a opção cortadora, a reformulação ficaria ambígua, já que segundo Suñer (2001), a preferência é pela oração com "que" a não ser que haja perda de interpretação. O mesmo ocorre com os dados dos nativos para a oração $\mathrm{E}$, que teve $83,3 \%$ das orações com a estrutura padrão com "prep. + art":

104. El traje con el que Juan visitó a su abuela es azul

Comparando os dois gráficos para a oração I, vemos que as produções dos estudantes brasileiros e a dos nativos são extremamente diferentes. Houve quase totalidade dos dados dos nativos para oração padrão "prep. + que" enquanto que os estudantes brasileiros produziram, em sua maioria, orações cortadoras e "prep. sem art." As orações padrão quase não foram produzidas pelos estudantes brasileiros, o que difere muito da produção dos nativos e nos comprova que o caráter definido do antecedente no $\mathrm{E}$ tem que ser retomado pelo artigo definido, o que, para os estudantes brasileiros, não necessariamente precisa ocorrer. 


\subsection{REFORMULAÇÕES DA ORAÇÃO J}

\section{Oração J:}

Mi padre me prestó el dinero. Yo no disponía del dinero.

\subsubsection{Gráfico das reformulações dos estudantes brasileiros de ELE}

Os informantes produziram os seguintes tipos de orações:

- Com preposição + artigo + que (padrão): Mi padre me prestó el dinero del que yo no disponía.

- Com preposição e sem artigo: Mi padre me presto el dinero de que yo no disponía.

- Sem preposição (cortadora): Mi padre me prestó el dinero que yo no disponía.

Evitação: Mi padre me prestó el dinero porque no lo disponía / Mi padre siempre me presta dinero. 


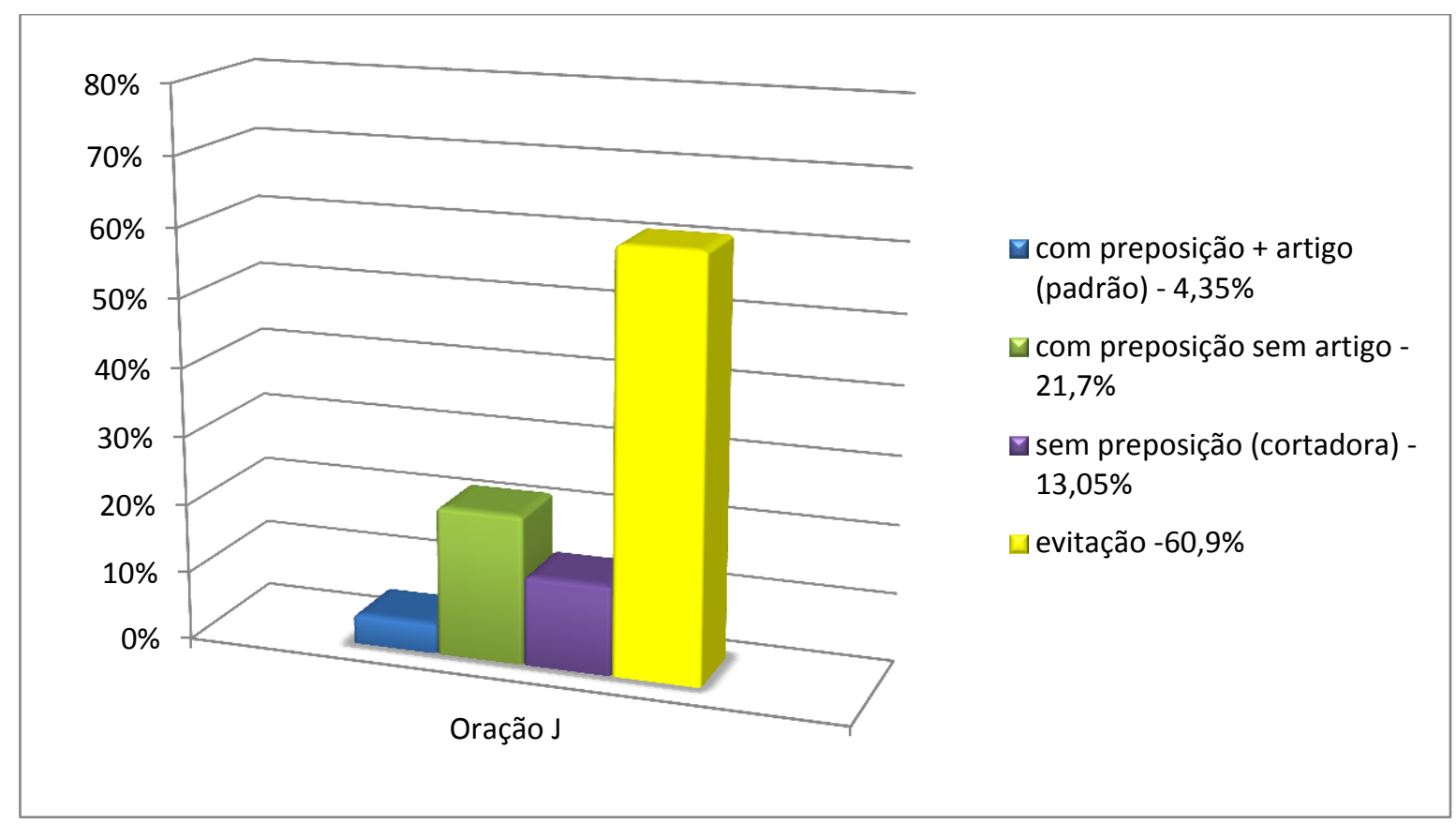

Gráfico 17 - Reformulações dos estudantes brasileiros de ELE para a oração J

Ocorreu uma grande incidência de evitações para esta reformulação (60,9\%), seguida pela oração com "prep. sem art." (21,7\%). Como ocorrido anteriormente (ver oração B), se observa um caráter causal na oração, reproduzido pelos informantes em suas reformulações de evitação:

102. Mi padre me ayudó prestándome un dinero ya que yo no disponía de nada.

Novamente os informantes brasileiros produziram mais orações com "prep. sem art." que cortadoras e um número mínimo produziu oração padrão. 
Como visto, segundo Brucart (1999), as orações com "prep. sem artigo" são agramaticais em espanhol com subordinadas de polaridade negativa (ver. 2.1.4), portanto, essas orações produzidas pelos estudantes brasileiros não seriam produzidas por nativos, já que a subordinada é negativa (yo no disponía).

É importante recordar que, devido ao caráter causal da oração, a produção de relativas foi prejudicada.

\subsubsection{Gráfico das reformulações dos Hispanofalantes}

Os informantes produziram os seguintes tipos de orações:

- Com preposição + artigo + que (padrão): Mi padre me prestó el dinero, del que yo no disponía.

- Com preposição e sem artigo: não houve ocorrências.

- Sem preposição (cortadora): não houve ocorrências.

Evitação: Mi padre me prestó dinero ya que yo no disponía. 


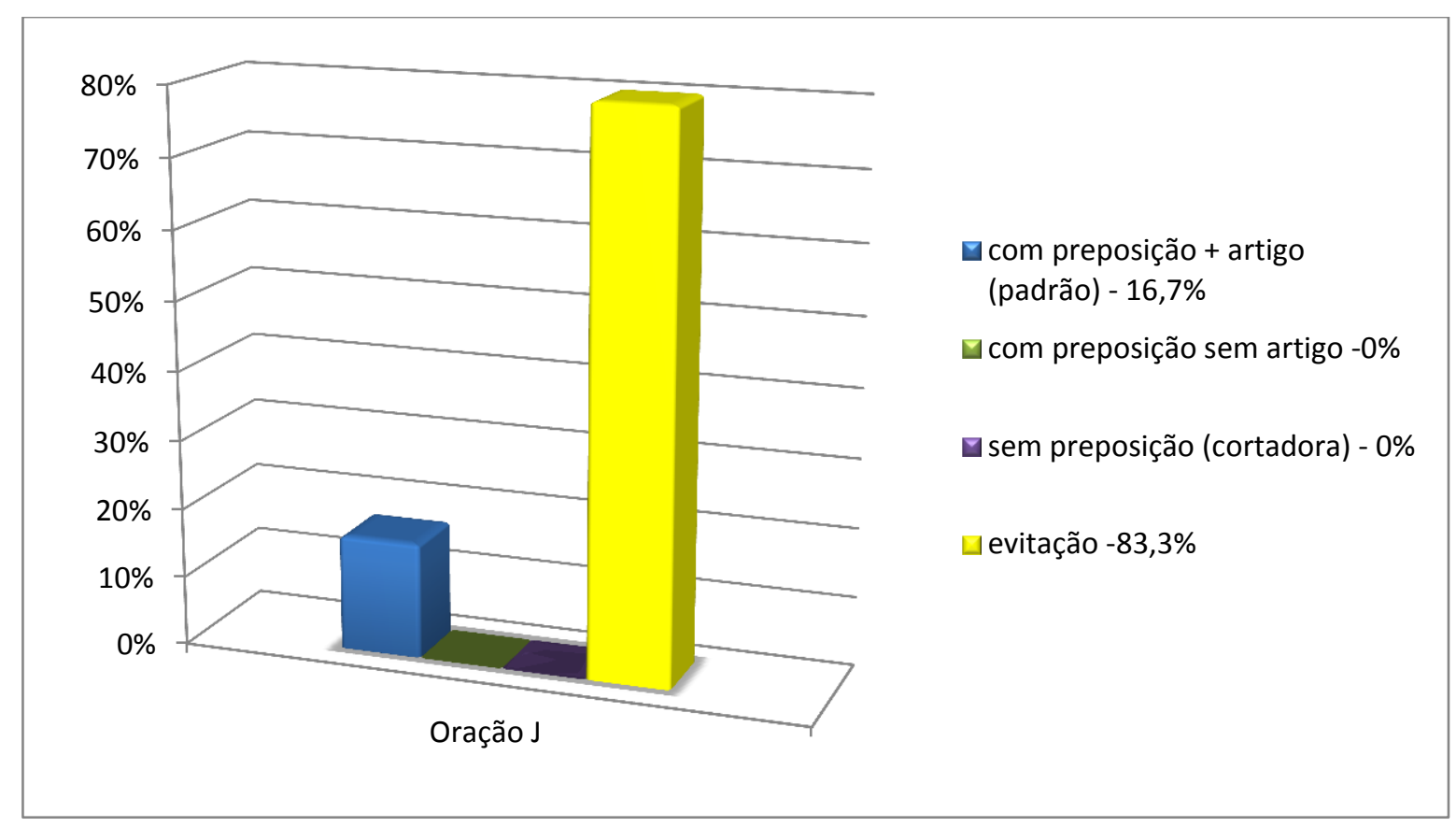

Gráfico 18 - Reformulações dos Hispanofalantes para a oração J

Os dados dos nativos não diferiram muito dos dados dos informantes brasileiros para esta oração. Apenas um informante realizou uma oração padrão com "prep. + art." (109). Todos os outros informantes usaram a evitação (110) e não realizaram nenhum tipo de oração relativa, devido, como já foi dito na análise do gráfico dos estudantes brasileiros, ao caráter causal da oração J.

109. Mi padre me prestó el dinero del que yo no disponía.

110. Mi padre me prestó el dinero porque no disponía de él.

Comparando os dois gráficos para a oração $\mathrm{J}$, vemos que a evitação também foi a opção mais usada pelos hispanofalantes, mas neste gráfico, não 
observamos usos de cortadora e "prep. sem artigo", usados em porcentagem baixa pelos estudantes brasileiros.

Vale lembrar que as orações com "prep. sem artigo" para este caso - com subordinada de polaridade negativa - são agramaticais em E.

Também podemos comparar estes dados com os da oração B, o que nos deixa evidente a dificuldade de realização de orações relativas com orações causais, tanto por parte dos nativos como dos estudantes brasileiros.

Como ocorreu nas reformulações para a oração B (ver 4.1.1 e 4.1.2), o caráter causal da oração pode haver desviado a atenção dos informantes da oração relativa. Mas comparando os gráficos para ambas as orações, vemos em B que o índice de evitações foi menor que em. J, para os estudantes brasileiros. Observamos que na oração $B$, há também o caráter locativo, que possibilitou a realização de orações com "prep. sem art.", que não são frequentes em E, o que levou os informantes brasileiros a não usarem a evitação em tão alto índice. 


\section{CONCLUSÕES}

Nesta dissertação, investigamos 0 uso das orações relativas especificativas com "que" no Espanhol, produzidas por estudantes brasileiros adultos de ELE e contrastadas com orações relativas de nativos adultos de E.

A partir dos dados recolhidos, encontramos cinco tipos de estruturas relativas usadas pelos informantes:

- - Padrão com "prep. + art. + que";

- - Padrão com "prep. + quien";

- - Cortadoras;

- - (prep. +) advérbio donde;

- - "prep. sem artigo + que".

Lembramos que os objetivos deste trabalho eram:

- Verificar a utilização do relativo acompanhado de preposição e artigo por estudantes brasileiros de ELE, quando e como o fazem;

- Verificar quais contextos favorecem a elipse de "preposição + artigo". 
Deparamo-nos com uma escassez de referências ao tema do uso do artigo definido nas orações relativas nas gramáticas descritivas do português. Essa foi uma dificuldade que encontramos ao começar a estudar o tema para poder entender as produções dos estudantes brasileiros. A única referência encontrada foi a tese de Brito (1988), que trata das orações relativas não no PB, mas sim no português europeu (PE) e, possivelmente, seja a fonte onde a descrição aparece mais detalhada e, por isto, foi usada em nossas análises.

Estamos conscientes de que os dados obtidos neste trabalho são apenas uma amostra e não permitem extrair conclusões gerais, mas, de qualquer maneira, nos permitiram uma aproximação às produções de nossos alunos e a comparação com a amostra de nativos nos esclareceu algumas questões e nos colocou outras interessantes que chamam a atenção para as dificuldades dos nativos e abrem o espaço de novas pesquisas de maior alcance.

Verificamos que, na maioria dos casos, as reformulações dos grupos de estudantes diferiram consideravelmente das reformulações do grupo de nativos. Os gráficos obtidos a partir das reformulações foram heterogêneos. É possível perceber essa heterogeneidade na produção das orações relativas especificativas dos estudantes brasileiros, quando comparamos as reformulações das diferentes orações entre si. Da mesma forma, surge a heterogeneidade quando são 
confrontados os resultados das produções dos estudantes com as produções dos nativos.

Os resultados para ambos os grupos, no geral, diferem do que esperávamos, pois Tarallo (1983) afirma que as orações cortadoras são as mais comuns na oralidade em PB, mas nos dados escritos dos estudantes brasileiros, tais orações não aparecem em uma porcentagem dominante. Suñer (2001), por sua vez, afirma que as orações mais usadas na oralidade pelos nativos de $E^{25}$ também seriam as cortadoras, o que tampouco foi o observado nos dados escritos dos nativos. Nossos dados diferem da bibliografia consultada, pois foram obtidos em outras condições, ou seja, possuem um caráter mais formal (escrito) e isso levou os informantes a produzirem orações mais condizentes com essa formalidade.

Esperávamos maior incidência das relativas cortadoras em todos os casos de reformulação dos estudantes brasileiros, mas vimos que, no geral, a oração mais produzida foi aquela que contém "prep. sem art.", com exceção de casos com antecedente [+ humano]. Também observamos a baixa incidência de orações cortadoras em orações locativas (como a F - La casa en la que / donde viví era muy grande), para os nativos. O que mostra que o que afirma Suñer

\footnotetext{
${ }^{25}$ De acordo com a generalização de seus dados, sugerida pela própria autora.
} 
(2001), que tais orações permitiriam o corte da preposição, não foi muito frequente no corpus.

Como esperado, os estudantes brasileiros realmente tiveram mais dificuldades com o uso da relativa padrão com preposição e artigo. Essa dificuldade já havia sido assinalada por Perroni (2001) no que concerne ao uso de relativas preposicionadas por brasileiros em PB. Já para os nativos, a relativa padrão com "que" foi a oração mais usada, demonstrando divergências quanto ao uso dessas estruturas pelos dois grupos.

Para melhor visualização das diferenças entre as possibilidades de orações relativas no $\mathrm{PB}$ e no $\mathrm{E}$, construímos a seguinte tabela ${ }^{26}$ :

\begin{tabular}{|c|l|l|}
\hline \multicolumn{1}{c|}{$\begin{array}{c}\text { Tipo de } \\
\text { antecedente }\end{array}$} & \multicolumn{1}{|c|}{ Português } & \multicolumn{1}{|c|}{ Espanhol } \\
\hline \multirow{3}{*}{ Sujeito (S) } & $\begin{array}{l}\text { (a). O homem que escreveu e meu } \\
\text { amigo. }\end{array}$ & $\begin{array}{l}\text { (a'). El hombre que vino te dejó esta } \\
\text { carta. } \\
\text { meu amigo. }\end{array}$ \\
\cline { 2 - 3 } & $\begin{array}{l}\text { (c). }{ }^{*} \text { O homem o qual escreveu é ém escreveu e } \\
\text { meu amigo. }\end{array}$ & $\begin{array}{l}\text { (b'). }{ }^{*} \text { El hombre quien vino te dejó } \\
\text { esta carta. } \\
\text { esta carta. }\end{array}$ \\
\hline & $\begin{array}{l}\text { (a). O homem que eu vi ontem é é cual vino te dejó } \\
\text { meu amigo. }\end{array}$ & $\begin{array}{l}\text { (a'). El autor que vimos en el } \\
\text { teatro... }\end{array}$ \\
\hline
\end{tabular}

\footnotetext{
${ }^{26}$ Todos os dados da tabela estão nos textos de Brucart (1999), Tarallo (1983) e Brito (1988), com exceção de OD(c), OD(d), OD(e) e OI(a)' (orações nossas) e OI(d'), oração de Marrero, (2004, p. 69).
} 


\begin{tabular}{|c|c|c|}
\hline \multirow[t]{6}{*}{$\begin{array}{c}\text { Objeto } \\
\text { Direto }(\mathrm{OD})\end{array}$} & $\begin{array}{l}\text { (b). }{ }^{*} \mathrm{O} \text { homem quem eu vi ontem é } \\
\text { meu amigo. }\end{array}$ & $\begin{array}{l}\text { (b'). }{ }^{*} \mathrm{El} \text { autor quien vimos en el } \\
\text { teatro... }\end{array}$ \\
\hline & $\begin{array}{l}\text { (c). A pessoa a quem me refiro não } \\
\text { está aqui. }\end{array}$ & $\begin{array}{l}\text { c'). La persona a quien me refiero no } \\
\text { está aquí. }\end{array}$ \\
\hline & (d). *O escritor ao que premiaram & $\begin{array}{l}\text { (d'). El escritor al que premiaron } \\
\text { anoche vendrá a nuestra tertulia } \\
\text { próximamente }\end{array}$ \\
\hline & $\begin{array}{l}\text { (e). O menino a que me refiro não } \\
\text { está aqui. }\end{array}$ & $\begin{array}{l}\left(e^{\prime}\right) .{ }^{*} E l \text { escritor a que premiaron } \\
\text { anoche vendrá a nuestra tertulia. }\end{array}$ \\
\hline & $\begin{array}{l}\text { (f). }{ }^{*} \mathrm{O} \text { homem o qual eu vi ontem é } \\
\text { meu amigo. }\end{array}$ & $\begin{array}{l}\text { (f'). }{ }^{*} \text { Ese es un tema el cual ha } \\
\text { estudiado a fondo. }\end{array}$ \\
\hline & $\begin{array}{l}\text { (g). Este tipo de oração não é } \\
\text { comentado nas amostras de } \\
\text { Tarallo ou Brito. }\end{array}$ & $\begin{array}{l}\text { (g'). [- humano] La empresa en que } \\
\text { trabajo desde hace dos años se } \\
\text { dedica a la chacinería. }\end{array}$ \\
\hline \multirow{4}{*}{$\begin{array}{c}\text { Objeto } \\
\text { Indireto }(\mathrm{OI})\end{array}$} & $\begin{array}{l}\text { (a). Este tipo de oração não é } \\
\text { comentado nas amostras de } \\
\text { Tarallo ou Brito. }\end{array}$ & $\begin{array}{l}\text { (a'). La niña a la que le di un helado } \\
\text { usa gafas. (H-D27) }\end{array}$ \\
\hline & $\begin{array}{l}\text { (b). Encontrei o rapaz a quem falaste } \\
\text { ontem. }\end{array}$ & $\begin{array}{l}\text { (b'). El profesor a quien no le } \\
\text { concedieron la venia docente. }\end{array}$ \\
\hline & $\begin{array}{l}\text { (c). Encontrei o rapaz ao qual falaste } \\
\text { ontem. }\end{array}$ & $\begin{array}{l}\text { (c'). Un policía de la brigada criminal } \\
\text { al cual le entregaron el arma } \\
\text { homicida. }\end{array}$ \\
\hline & $\begin{array}{l}\text { (d). ? Encontrei o rapaz a que falaste } \\
\text { ontem. (com prep. "a", "de", "com" e } \\
\text { "em") } \\
\text { (e). [- humano] "A instituição para } \\
\text { que fiz o relatório funciona } \\
\text { (com prep. "por" e "para" - } \\
\text { agramatical) }\end{array}$ & $\begin{array}{l}\text { (d'). "Primero, es su... tiene un } \\
\text { séquito que la defiende; después, } \\
\text { tiene un marido a que se la entregan } \\
\text { vestida de novia, y después se } \\
\text { muere. }\end{array}$ \\
\hline
\end{tabular}


Podemos notar que para as orações (OI.a') não há uma correspondência encontrada em PB. Tarallo (1983) e Brito (1988) não citam este tipo de oração como gramatical, agramatical ou improvável/ estranha, elas não aparecem nos dados dos autores, como se não existissem. Portanto, pensamos que uma oração como "A menina à que dei o sorvete.../ O menino ao que dei o sorvete..." não seria realizável em $\mathrm{PB}$.

Pensamos que a inexistência de tal oração no PB explicaria a pouca incidência deste tipo de oração nos nossos dados realizados pelos estudantes brasileiros, que preferiram cortar o artigo (111) ou usar o relativo "quien" (112) a realizar tais opções nas reformulações.

111. La mujer con que estoy casado hace 20 años es linda. (D-C19)

112. La mujer con quien estoy casado hace 20 años es linda. (D-A6)

Chamou-nos a atenção a realização, em grande número, de opções com "prep. sem art." por parte dos estudantes brasileiros, como em (111). Essa preferência pelas estruturas sem artigo não foi observada nas amostras dos nativos, que produziram reformulações com estruturas distintas para as mesmas orações. 
Vemos nas orações (Ol.d) e (OI.d') da tabela que, com antecedente [+ humano] no E, tais estruturas são agramaticais e no PB, Brito (1988) as considera como orações improváveis/ estranhas. Esta classificação no PB é comprovada pela baixa frequência deste tipo de oração (113) nos dados dos estudantes brasileiros.

113. La mujer con que estoy casado hace 20 años es linda. (D-B8)

A autora afirma que com antecedente [+ humano]' a sequência "preposição a/com + que" não é possível em português; é exigido o uso de "quem" ou de "o qual":

114. a.? Encontrei o rapaz a que falaste ontem

b. Encontrei o rapaz a quem falaste ontem

c. Encontrei o rapaz ao qual falaste ontem (BRITO, op. cit., p.246)

No espanhol as possibilidades com antecedente [+humano] e a preposição "a" são as seguintes:

115. a. El escritor al que premiaron....

b. * El escritor a que premiaron.... (BRUCART, op.cit., p. 491) 
C. El escritor a quien premiaron ${ }^{27} \ldots$

É possível comprovar que, com antecedente [+ humano], em nenhuma das duas línguas é possível obter a sequencia "a + que". A diferença está no fato de o espanhol, com antecedente [+ humano], admitir essa sequência se o artigo está presente. O português não admite o uso do artigo com o elemento "que". Isso nos permite aventurar a hipótese de que a diferença esteja nas características desse elemento "que" nas duas línguas.

Como visto no subcapítulo 2.2.3, que trata dos artigos definidos no PB, Brito (1988) afirma que o morfema "que", quando precedido de preposição, é um relativo sem traços de concordância, tanto para o Português como para o Castelhano ${ }^{28}$. Portanto, esperávamos dados semelhantes para os dois grupos de informantes. Mas como vimos, os nativos produziram em grande quantidade orações com preposição e artigo. É possível que o relativo "que" do Português não possua traços de concordância e o "que" do Espanhol possua traços de concordância "abstratos", ou seja, não apareçam realizados morfologicamente, mas possibilitem a concordância com o determinante, que, por sua vez, concorda com o antecedente. Talvez isso faça com que os informantes nativos usem o

27 Oração nossa. Uma oração equivalente nos dados de Brucart, é El profesor a quien no Le concedieron la venia docente. Ver Brucart, op. cit.p. 404, ex. (15).

28 Usamos "castelhano" para manter o vocabulário usado pela autora. 
artigo nas relativas para revelar os traços de concordância que o antecedente relativo não tem possibilidade de mostrar.

Nossos dados para antecedente [+ humano] nos mostram divergências quanto ao que predizem as gramáticas, tanto para os dados dos estudantes brasileiros como para os dados dos nativos. Os estudantes brasileiros nem sempre preferiram o uso de relativas com "quien" para tal antecedente. Aliás, o uso das duas orações padrão ("prep. + quien" e "prep.+ art. + que) foi bastante equilibrado. Os nativos de E, para o mesmo tipo de antecedente, usaram a oração padrão com o relativo "que" com maior frequência.

Para antecedente [- humano], observamos na oração (OI.e) que tal construção é agramatical no PB com determinadas preposições. Brito (1988, p. 313) afirma que "com certas PREPs, se o antecedente é [- humano], é exigido o emprego do morfema o qual", por exemplo, com as preposições "por" e "para" (116a e 116b). Tal morfema pode ser empregado com antecedentes [+/humanos], mas é obrigatório se precedido das preposições e locuções prepositivas como "contra", "sob", "sobre", "segundo", "perante", "através de" com antecedente [+ humano] (117a) e (117b):

116. a. A instituição para a qual fiz o relatório funciona bem. 
b. * A instituição para que fiz o relatório funciona bem. (BRITO, 1988, p. 313)

117. a. O júri perante o qual foi apresentada a tese teve a sua primeira reunião.

b. * O júri perante que foi apresentada a tese teve a sua primeira reunião. (BRITO, 1988, p. 314)

Portanto, a oração (Ol.e) - na tabela - é agramatical. Mas com outras preposições, que eram o foco de nosso trabalho, nossos dados mostram a realização de estruturas sem o artigo por estudantes brasileiros (118) e (119) e, em minoria, por nativos (120) e (121):

118. La empresa en que trabajo hace 10 años va a cerrar. (C-A5)

119. El traje con que Julio visitó a su abuela es azul. (E-C18)

120. La casa en que yo viví allí es muy grande. (F-D27)

121. La mujer de que hablamos no era Juana. (G-D24)

Concluímos que os brasileiros, em sua língua nativa, talvez não usassem tal estrutura (prep. sem artigo), mas quando têm que lidar com o E, cortam o artigo ao invés de produzir uma estrutura que seja mais comum em PB - como a cortadora. 
Sobre as evitações, vimos que quando a oração apresentou aspecto causal, os informantes brasileiros e nativos foram levados a expressar essa relação e evitaram a oração relativa. Dois informantes nativos produziram orações relativas e adicionaram, ainda, algum conector ou preposição de causalidade. Em orações como as de $\mathrm{B}$ e $\mathrm{J}$, podemos constatar essa dificuldade em realizar a subordinada relativa em orações de causalidade.

Os dados aqui apresentados constituem uma amostra e, para um trabalho futuro, seria interessante acrescentar uma quantidade maior de dados, tanto de estudantes brasileiros quanto de nativos.

Estamos cientes que há muito que se pesquisar sobre as orações relativas e que algumas questões foram deixadas abertas neste estudo, como o uso do artigo neutro "lo", a presença de antecedentes indefinidos, o uso do artigo indefinido nas orações relativas e antecedentes [- humano] acompanhados das preposições que exigem uso de "o qual" em PB ("contra", "sob", "sobre", "segundo", "perante", "através de"), que, devido aos limites deste trabalho, não foi possível que trabalhássemos. 


\section{REFERÊNCIAS BIBLIOGRÁFICAS}

ALARCOS LLORACH, E. Gramática de la Lengua Española. Madrid: Espasa Calpe, 2008.

BAGNO, M. Português ou Brasileiro? Um convite à pesquisa. São Paulo: Parábola, 2001.

BELLO, Andrés. Pronombres Relativos, y Primeramente el Relativo Que. In: Bello, Andrés. Gramática de la Lengua Castellana. Destinada al uso de los americanos. Madrid: Arcos Libros, 1988.

BRAGA, M.L.; R, ILARI; R.P, OLIVEIRA; R.M. BASSO. Artigo Definido. In: ILARI. R; M.H.M, NEVES (Orgs.). Gramática do Português Culto Falado no Brasil, v.ll. Campinas: Unicamp, 2008.

BRITO. A.M.B. A sintaxe das orações relativas em português: Estrutura, mecanismos interpretativos e condições sobre a distribuição dos morfemas relativos. 1988. 437f. Tese (Doutorado em Linguística Portuguesa). Faculdade de Letras, Universidade do Porto. Porto, 1988.

BRUCART, J.M. Gramática y adquisición en la enseñanza del español como lengua extranjera. ASELE. Actas VII. Barcelona: Universitat Autónoma de Barcelona, 1996.

BRUCART, J. M. La estructura del sintagma Nominal: Las oraciones de relativo. In: BOSQUE, I. \& DEMONTE, V. (dir.): Gramática descriptiva de la lengua española, vol. I. Madrid: Espasa, 1999. 
CINQUE, Guglielmo. La sintassi dei pronomi relativi 'cui' e 'quale' nell'italiano moderno. Rivista di Grammatica Generativa. Padova: Unit Press. Vol. 3, p. 31-126. 1978,

On the theory of relative clauses and markedness. The Linguistic Review.

Vol. 1. Boston: De Gruyter Mouton. p. 247-294, out.1982.

CORREA, W. R. Orações relativas: o que se fala e o que se aprende no Português do Brasil. 1998. 165f. Tese (Doutorado) - IEL, Unicamp, Campinas. 1998.

GONZÁLEZ, N.T.M. Cadê o pronome? O gato comeu. Os pronomes pessoais na aquisição/aprendizagem do espanhol por brasileiros adultos. 1994. Tese (Doutorado) - FFLCH, USP, São Paulo. 1994.

GUTIÉRREZ ORDÓÑEZ, S. Temas, Remas, Focos Tópicos y Comentarios. 2 ed. Madrid: Arco Libros, 2000.

KAYNE, R.S. French Relative "que" in LUJÁN, M.; HENSEY, F. G. Current Studies in Romance Linguistics. Washington: Georgetown University Press, 1976.

KENEDY, E. As orações relativas preposicionadas e a hipótese da antinaturalidade de pied-piping. Revista de Estudos Lingüísticos Veredas, Minas Gerais: Editora da UFJF. Vol. 2, p.92 - 111, fev. 2008.

LICERAS, J.M. La adquisición de las lenguas segundas y la gramática universal. Madrid: Síntesis, 1996. 
LICERAS, J.M. Linguistic Theory and Second Language acquisition - The spanish nonnative gramar of english speakers. Tübingen: Gunter NarrVerlagTübingen, 1986.

LOPE BLANCH, J.M. Despronominalización de los relativos. Estudios de lingüística española. Ciudad de México: UNAM, p. 257-272, jan/fev. 1986.

MARRERO, J.S. Preposición + (artículo) + que relativo: análisis en la norma lingüística culta panhispánica. Boletín de Lingüística, Caracas: UCV, n. 21, p. 66-91. 2004.

OLIVEIRA, M. Estratégias de relativização e tipologia anafórica: um caso de aprendizagem formal. In: Ataliba Teixeira de Castilho. (Org.). Sintaxe e aquisição. Campinas: Unicamp, 2007.

PERRONI, M. C. As relativas que são fáceis na aquisição do português brasileiro. DELTA. Documentação de Estudos em Lingüística Teórica e Aplicada, São Paulo, v. 17, n. 1, p. 59-79, 2001

PORTO DAPENA, José-Álvaro. Oraciones de relativo. Cuadernos de Lengua Española. Madrid: Arco Libros, 1997.

ROBERTS, I.; M.A. KATO (orgs.). Português Brasileiro. Uma viagem diacrônica. Homenagem a Fernando Tarallo. Campinas: Editora da Unicamp, 1993.

Real Academia Española. Esbozo de uma nueva gramática de la lengua española. Madrid: Espasa-Calpe, 1973.

RAMSEY, M. A Textbook of Modern Spanish. New York: Holt, Rinehart and Winston, 1956. 
SOLÉ, Y.; C., SOLÉ. Modern Spanish Syntax: A Study in Contrast. Lexington, MA: Heath and Co., 1977.

SUÑER, M. Las cláusulas relativas especificativas en el español de Caracas. Boletin de lingüística. Caracas, U.C.V., v. 16, p. 7-43, 2001.

TARALLO, F. Relativization Strategies in Brazilian Portuguese. 1983. 273f. Tese (Doutoramento em Filosofia), Universidade da Pensilvânia, USA. 1983. . Sobre a alegada origem crioula do português brasileiro: mudanças sintáticas aleatórias. In: I. ROBERTS, \& M. A. KATO (Orgs.). Português brasileiro; umaviagem diacrônica. Campinas: Editora da UNICAMP, 1993.

TRUJILLO, R. Sobre la Supuesta Despronominalización del Relativo. E.L.U.A, Alicante, n.6, 23-45, 1990.

YOKOTA, R. O que eu falo não se escreve. E o que eu escrevo alguém fala? A variabilidade no uso do objeto anafórico na produção oral e escrita de aprendizes brasileiros de espanhol. 2007. 219f. Tese (Doutorado) - USP, 2007. 


\section{ANEXOS}

\subsection{ANEXO 1 - FICHA DOS INFORMANTES BRASILEIROS}

Nombre:

Fecha:

Curso/ nivel:

Edad:

( ) hasta 20 años

( ) de 30 a 35 años

( ) de 45 a 50 años

Sexo:

( ) femenino

Estudios

( ) Enseñanza media/secundaria

( ) Maestría
( ) de 20 a 25 años

( ) de 35 a 40 años

( ) de 50 a 60 años

( ) masculino

( ) Curso Universitario

( ) Doctorado de 25 a 30 años

( ) de 40 a 45 años

( ) más de 60 años

Profesión:

Si trabajas con traducción: ¿En qué lengua y hace cuánto tiempo?

¿Qué idiomas hablas? ¿Qué nivel de conocimiento crees que tienes en cada uno de ellos?

1- Muy bueno / 2 - bueno / 3- regular / 4 - básico

\begin{tabular}{|l|l|l|l|l|}
\hline \multirow{2}{*}{ Idioma } & \multicolumn{5}{|c|}{ Nivel de conocimiento } \\
\hline & 1 & 2 & 3 & 4 \\
\hline 1. & & & & \\
\hline 2. & & & & \\
\hline 3. & & & & \\
\hline 4. & & & & \\
\hline 5. & & & & \\
\hline
\end{tabular}

¿Dónde / Cómo has estudiado español?
( ) en la escuela
( ) en instituto de lenguas
( ) con clases particulares
( ) otros

Hasta hoy, ¿cuántos semestres de clase has hecho?

¿En qué país naciste?

¿Cuál es el origen de tu familia? (Si tiene más de un origen, escribe todos)

¿Te relacionas con hispanohablantes personal o profesionalmente? ( ) sí

¿Cuándo? ¿Dónde? (en el trabajo, en casa, con amigos...)

¿Con qué frecuencia?

( ) siempre

( ) muchas veces

( ) a veces

( ) casi nunca

¿Ya has viajado a algún país hispanohablante?

¿Con qué objetivo?

( ) turismo

( ) sí

( ) trabajo

( ) no

¿Por cuántos días?

( ) de 1 a $15 \quad$ ( ) de 15 a 30

( ) de 30 a 60

( ) otros

( ) más de 60 


\subsection{ANEXO 2 - FICHA DOS INFORMANTES HISPANOFALANTES}

Nombre: Fecha:
Edad:
( ) hasta 20 años
( ) de 20 a 25 años
( ) de 25 a 30 años
( ) de 30 a 35 años
( ) de 35 a 40 años
( ) de 40 a 45 años
( ) de 45 a 50 años
( ) de 50 a 60 años
( ) más de 60 años
Sexo:
( ) femenino
( ) masculino
Estudios:
( ) Enseñanza media/secundaria
( ) Curso Universitario
( )Especialización
( ) Maestría
( ) Doctorado

Profesión:

Si trabajas con traducción: ¿En qué lengua(s) y hace cuánto tiempo?

¿Qué idiomas hablas? ¿Qué nivel de conocimiento crees que tienes en cada uno de ellos?

1- Muy bueno / 2 - bueno / 3- regular / 4 - básico

\begin{tabular}{|l|l|l|l|l|}
\hline \multirow{2}{*}{ Idioma } & \multicolumn{5}{|c|}{ Nivel de conocimiento } \\
\hline & 1 & 2 & 3 & 4 \\
\hline 1. & & & & \\
\hline 2. & & & & \\
\hline 3. & & & & \\
\hline 4. & & & & \\
\hline 5. & & & & \\
\hline
\end{tabular}

¿Dónde / Cómo has estudiado otras lenguas?
( ) en la escuela
( ) en instituto de lenguas
( ) con clases particulares
( ) otros

¿En qué país naciste?

¿Cuál es el origen de tu familia? (Si tiene más de un origen, escribe todos)

¿Te relacionas con brasileños o hablantes de portugués personal o profesionalmente? ( ) sí （ ）no ¿Cuándo? ¿Dónde? (en el trabajo, en casa, con amigos...)
¿Con qué frecuencia?
( ) siempre
( ) muchas veces
( ) a veces
( ) casi nunca
¿Ya has viajado a Brasil?
( ) sí
( ) no
¿Con qué objetivo?
( ) turismo
( ) estudio
( ) trabajo
( ) otros

¿Por cuántos días? () de 1 a $15 \quad$ ( ) de 15 a $30 \quad$ ( ) de 30 a $60 \quad$ ( ) más de 60 


\subsection{ANEXO 3 - TESTE PARA INFORMANTES BRASILEIROS E HISPANOFALANTES}

Reformula las construcciones uniéndolas en una sola oración y manteniendo el mismo sentido. No debes usar "cual", "cuyo" tampoco la "y":

a. Ese es el profesor. A él le debes entregar una reseña semanalmente.

El profesor

b. Vivo en un edificio muy antiguo. El edificio tiene un ascensor que nunca funciona.

El edificio

c. Esta es la empresa. En esta empresa trabajo hace 10 años.

La empresa

d. Esta la mujer. Estoy casado con ella hace 20 años.

La mujer

e. Juan fue con un traje azul. Con este traje visitó a su abuela.

El traje

f. Viví en una casa azul. La casa era muy grande.

La casa

g. Hablábamos de una mujer. La mujer no era Juana.

La mujer

h. Esta es la niña. A la niña le di un helado.

La niña

i. Le regalé una pluma. Con la pluma había escrito algunas de mis novelas.

Le regalé a Luís

j. $\quad$ Mi padre me prestó el dinero. Yo no disponía el dinero.

Mi padre 


\section{4 - Reformulações dos informantes}

Grupo A - Estudantes de ELE - três semestres: Curso regular do Centro de Línguas da Faculdade de Filosofia, Letras e Ciências Humanas - CL-FFLCH da Universidade de São Paulo - USP.

Grupo B - Estudantes de ELE - quatro semestres: Curso regular do Centro de Línguas da Faculdade de Filosofia, Letras e Ciências Humanas - CL-FFLCH da Universidade de São Paulo - USP.

Grupo C - Estudantes de Graduação em Letras - Português/Espanhol: Faculdade de Filosofia, Letras e Ciências Humanas - FFCLH da Universidade de São Paulo - USP.

Grupo D - Hispanofalantes: Informantes adultos da cidade de Buenos Aires, Argentina. 
Oração A - Ese profesor es muy exigente. A él le debes entregar una reseña semanalmente.

\begin{tabular}{|c|c|}
\hline \multicolumn{2}{|r|}{ Oração A - Ese profesor es muy exigente. A él le debes entregar una reseña semanalmente. } \\
\hline $\begin{array}{c}\text { Grupo } \\
\text { A }\end{array}$ & $\begin{array}{l}\text { 1. El profesor es muy exigente. A él debes entregar una reseña semanalmente. } \\
\text { 2. El profesor pide para entregarle una reseña semanalmente porque es muy exigente. } \\
\text { 3. El profesor exige que le entregues una reseña semanalmente. } \\
\text { 4. El profesor piede que la resena le seja entregue semanalmente. } \\
\text { 5. El profesor es muy exigente debemos entregarle una reseña semanalmente. } \\
\text { 6. El profesor es muy exigente porque semanalmente sus alumnos deven le entregar una reseña. } \\
\text { 7. El profesor es muy exigente, porque a él le debes entregar una reseña semanalmente. }\end{array}$ \\
\hline $\begin{array}{c}\text { Grupo } \\
\text { B }\end{array}$ & $\begin{array}{l}\text { 8. El profesor es muy exigente, porque a él le debes entregar una reseña. } \\
\text { 9. El profesor al que le debes entregar una reseña semanalmente es muy exigente. } \\
\text { 10.El profesor es muy exigente, entonces debes entregar a él una reseña semanalmente. } \\
\text { 11.El profesor es muy exigente pues exige que entregamos una reseña semanalmente. } \\
\text { 12.El profesor es muy exigente porque le gusta pedir una reseña semanalmente. } \\
\text { 13.El profesor a quien le debes entregar una reseña es muy exigente. } \\
\text { 14.El profesor exigente nos pide que entreguemos a él una reseña semanalmente. } \\
\text { 15.El profesor que es muy exigente pide que le entregues una reseña semanalmente. } \\
\text { 16.El profesor es muy exigente, así que le debes entregar una reseña semanalmente. }\end{array}$ \\
\hline $\begin{array}{c}\text { Grupo } \\
\text { C }\end{array}$ & $\begin{array}{l}\text { 17.El profesor al que le debes entregar una reseña semanalmente es muy exigente. } \\
\text { 18.El profesor es muy exigente luego le debes entregar una reseña semanalmente. } \\
\text { 19.El profesor exige demasiado hay que entregarle todas las semanas una reseña. } \\
\text { 20.El profesor exige que le entreguemos una reseña semanalmente. } \\
\text { 21.El profesor es muy inteligente, lo debes entregar una reseña semanalmente. } \\
\text { 22.El profesor exige que se le entregue una reseña semanalmente. } \\
\text { 23.El profesor es exigente porque le debemos entregar una reseña semanalmente. }\end{array}$ \\
\hline $\begin{array}{c}\text { Grupo } \\
\text { D }\end{array}$ & $\begin{array}{l}\text { 24.El profesor a quien debemos entregar una reseña semanalmente es muy exigente. } \\
\text { 25.El profesor ese es muy exigente, semanalmente le debes entregar una reseña. } \\
26 \text {.El profesor es muy exigente ya que le debes entregar una resena semanalmente. } \\
\text { 27.El profesor es muy exigente porque debemos entregar una reseña semanalmente. } \\
\text { 28.El profesor es muy exigente, debemos entregar una reseña semanalmente. } \\
\text { 29.El profesor es muy exigente, a él le debes entregar una reseña semanalmente. }\end{array}$ \\
\hline
\end{tabular}




\begin{tabular}{|c|c|}
\hline \multicolumn{2}{|c|}{$\begin{array}{l}\text { Oração B - Vivo en un edificio muy antiguo. El edificio tiene un ascensor que nunca } \\
\text { funciona. }\end{array}$} \\
\hline$\underset{A}{\text { Grupo }}$ & $\begin{array}{l}\text { 1. El edificio donde vivo es muy antiguo, tiene un ascensor que nunca funciona. } \\
\text { 2. El edificio antiguo que vivo tiene un ascensor que nunca funciona. } \\
\text { 3. El edificio es muy antiguo su ascensor nunca funciona. } \\
\text { 4. El edificio donde vivo es muy antiguo e el ascensor quedase siempre parado. } \\
\text { 5. El edificio que vivo es muy antiguo hay un ascensor que nunca funciona. } \\
\text { 6. El edificio en que vivo es muy antiguo, por eso su ascensor nunca funciona. } \\
\text { 7. E edificio antiguo en que vivo tiene un ascensor que nunca funciona. }\end{array}$ \\
\hline $\begin{array}{l}\text { Grupo } \\
\text { B }\end{array}$ & $\begin{array}{l}\text { 8. El edificio en que vivo es tan antiguo que tiene un ascensor que nunca funciona. } \\
\text { 9. El edificio en que vivo tiene un ascensor que nunca funciona porque el predio es muy antiguo. } \\
\text { 10.El edificio tiene un ascensor que nunca funciona, por ser antiguo. } \\
\text { 11.El edificio que habito es tan antiguo que el ascensor nunca funciona. } \\
\text { 12.El edificio en que vivo es tan antiguo que tiene un ascensor que nunca funciona. } \\
\text { 13.El edificio en que vivo tiene un ascensor que nunca funciona, eso porque es muy antiguo. } \\
\text { 14.El edificio que vivo es muy antiguo, el tiene un ascensor que nunca funciona. } \\
\text { 15.El edificio tiene un ascensor que nunca funciona, pues es un edificio muy antiguo } \\
\text { 16. El edificio en que vivo es muy antiguo, por eso tiene un ascensor que nunca funciona. }\end{array}$ \\
\hline$\underset{\mathrm{C}}{\text { Grupo }}$ & $\begin{array}{l}\text { 17. El edificio donde vivo es tan antiguo que tiene un ascensor que nunca funciona. } \\
\text { 18.El edificio es tan antiguo que el ascensor nunca funciona. } \\
\text { 19. El edificio en que vivo es muy antiguo en que además no funciona el ascensor. } \\
\text { 20.El edificio muy antiguo tiene un ascensor que nunca funciona. } \\
\text { 21.El edificio en que vivo tiene un ascensor que nunca funciona, es un edificio muy antiguo. } \\
\text { 22.El edificio antiguo en que vivo tiene un ascensor que nunca funciona. } \\
\text { 23.El edificio es muy antiguo que tiene un ascensor que nunca funciona. }\end{array}$ \\
\hline $\begin{array}{c}\text { Grupo } \\
\text { D }\end{array}$ & $\begin{array}{l}\text { 24.El edificio tiene un ascensor que nunca funciona que vivo en un edificio muy antiguo. } \\
\text { 25.El edificio donde vivo es muy antiguo, tiene un ascensor que nunca funciona. } \\
26 \text {.El edificio en el que vivo es muy antiguo por lo tanto tiene un ascensor que nunca funciona. } \\
\text { 27. El edificio tiene un ascensor que nunca funciona, pues vivo en un edificio muy antiguo. } \\
\text { 28. El edificio tiene un ascensor que nunca funciona porque vivo en un edificio muy antiguo. } \\
\text { 29.El edificio donde vivo es muy antiguo ya que tiene un ascensor que nunca funciona. }\end{array}$ \\
\hline
\end{tabular}




\section{Oração C - Esta empresa va a cerrar. En esta empresa trabajo hace 10 años.}

\begin{tabular}{|c|c|}
\hline$\underset{A}{\text { Grupo }}$ & $\begin{array}{l}\text { 1. La empresa donde trabajo a } 10 \text { años va a cerrar. } \\
\text { 2. La empresa que trabajo hace } 10 \text { años va a cerrar. } \\
\text { 3. La empresa que trabajo hace } 10 \text { años va a cerrar. } \\
\text { 4. La empresa que trabajo hace } 10 \text { años va a cerrar. } \\
\text { 5. La empresa en que trabajo hace } 10 \text { años irá cerrar. } \\
\text { 6. La empresa en que trabajo hace } 10 \text { años irá cerrar. } \\
\text { 7. La empresa en que trabajo hace } 10 \text { años irá cerrar. }\end{array}$ \\
\hline $\begin{array}{c}\text { Grupo } \\
\text { B }\end{array}$ & $\begin{array}{l}\text { 8. La empresa en que trabajo hace } 10 \text { años va a cerrar. } \\
\text { 9. La empresa en que trabajo hace } 10 \text { años va a cerrar. } \\
\text { 10.La empresa en que trabajo hace } 10 \text { años va a cerrar. } \\
\text { 11.La empresa que me contrata hace } 10 \text { años va a cerrar. } \\
\text { 12.La empresa que trabajo hace } 10 \text { años va a cerrar. } \\
\text { 13.La empresa donde trabajo hace } 10 \text { años va a cerrar. } \\
\text { 14.La empresa que trabajo hace } 10 \text { años va a cerrar. } \\
\text { 15.La empresa en que trabajo hace } 10 \text { años va a cerrar. } \\
\text { 16.La empresa en la que trabajo hace } 10 \text { años va a cerrar. }\end{array}$ \\
\hline $\begin{array}{c}\text { Grupo } \\
\text { C }\end{array}$ & $\begin{array}{l}\text { 17.La empresa en la que trabajo hace } 10 \text { años va a cerrar. } \\
\text { 18.La empresa en que trabajo hace } 10 \text { años se va a cerrar. } \\
\text { 19.La empresa en que trabajo hace } 10 \text { años se va a cerrar. } \\
\text { 20.La empresa que va a cerrar es donde trabajo hace } 10 \text { años. } \\
\text { 21.La empresa en que trabajo hace } 10 \text { años se va a cerrar. } \\
\text { 22.La empresa en que trabajo hace } 10 \text { años se va a cerrar. } \\
\text { 23.La empresa que yo trabajo hace } 10 \text { años, va a cerrar. }\end{array}$ \\
\hline $\begin{array}{c}\text { Grupo } \\
\text { D }\end{array}$ & $\begin{array}{l}\text { 24.La empresa que trabajo hace diez años va a cerrar. } \\
\text { 25.La empresa en la que trabajo hace } 10 \text { años, va a cerrar. } \\
\text { 26.La empresa en la que trabajo hace } 10 \text { anos va a cerrar. } \\
\text { 27.La empresa que trabajo hace diez años va a cerrar. } \\
\text { 28.La empresa en donde trabajo hace diez años va a cerrar. } \\
\text { 29.La empresa va a cerrar, es donde trabajo desde hace } 10 \text { años }\end{array}$ \\
\hline
\end{tabular}


Oração E - Este traje es azul. Con este traje Julio visitó a su abuela.

\begin{tabular}{|c|c|}
\hline \multicolumn{2}{|r|}{ Oração E - Este traje es azul. Con este traje Julio visitó a su abuela. } \\
\hline $\begin{array}{c}\text { Grupo } \\
\text { A }\end{array}$ & $\begin{array}{l}\text { 1. El traje que Julio visito a su abuela es azul. } \\
\text { 2. El traje a que Julio visitó su abuela es azul. } \\
\text { 3. El traje que Julio visito a su abuela es azul } \\
\text { 4. El traje me hace recordar mi abuela. } \\
\text { 5. El traje azul vestió Julio para visitar a su abuela. } \\
\text { 6. El traje azul de Julio fue utilizado en la visita a su abuela. } \\
\text { 7. El traje con que Julio visitó a su abuela es azul. }\end{array}$ \\
\hline $\begin{array}{c}\text { Grupo } \\
\text { B }\end{array}$ & $\begin{array}{l}\text { 8. El traje azul con que Julio visitó a su abuela es este aquí. } \\
\text { 9. El traje con que Julio visitó a su abuela es azul. } \\
\text { 10.El traje con que Julio visitó a su abuela es azul. } \\
\text { 11.El traje que Julio usó para visitar a su abuela era azul. } \\
\text { 12.El traje con cual Julio visitó a su abuela es azul. } \\
\text { 13.El traje que Julio se puso para visitar a su abuela es azul. } \\
\text { 14.El traje azul fue utilizado por Julio para visitar a su abuela. } \\
\text { 15.El traje azul hay sido usado por Julio cuando hay visitado su abuela. } \\
\text { 16.El traje con que Julio visitó a su abuela es azul. }\end{array}$ \\
\hline $\begin{array}{c}\text { Grupo } \\
\text { C }\end{array}$ & $\begin{array}{l}\text { 17.El traje con el que Julio visitó a su abuela es azul. } \\
\text { 18.El traje con que Julio visitó a su abuela es azul. } \\
\text { 19.El traje con que Julio visitó a su abuela es azul } \\
\text { 20.El traje azul es el que Julio visitó a su abuela. } \\
\text { 21.El traje con lo que Julio visito su abuela es azul. } \\
\text { 22.El traje con que Julio visitó a su abuela es azul } \\
\text { 23.El traje que Julio visitó a su abuela es azul. }\end{array}$ \\
\hline Grupo & $\begin{array}{l}24 \text {.El traje con el que Juan visito a su abuela es azul } \\
25 \text {.El traje con el que Julio visitó a su abuela, es azul. } \\
26 \text {.El traje con el que Julio visito a su abuela es azul. } \\
27 . \text { El traje con el que Juan visito a su abuela es azul. } \\
\text { 28.El traje con el que Juan visito a su abuela es azul. } \\
\text { 29.El traje es azul, con él Julio visitó a su abuela. }\end{array}$ \\
\hline
\end{tabular}


Oração F - La casa era muy grande. Yo viví allí.

\begin{tabular}{|c|c|}
\hline $\begin{array}{c}\text { Grupo } \\
\text { A }\end{array}$ & $\begin{array}{l}\text { 1. La casa donde viví era muy grande es esta allí. } \\
\text { 2. La casa que yo viví era muy grande. } \\
\text { 3. La casa en que yo viví era muy grande. } \\
\text { 4. La casa donde viví era muy grande. } \\
\text { 5. La casa en que viví era muy grande. } \\
\text { 6. La casa en que viví era muy grande. } \\
\text { 7. La casa en que viví era muy grande. }\end{array}$ \\
\hline $\begin{array}{c}\text { Grupo } \\
\text { B }\end{array}$ & $\begin{array}{l}\text { 8. La casa en que viví era muy grande. } \\
\text { 9. La casa en que yo viví era muy grande } \\
\text { 10. La casa donde viví era muy grande. } \\
\text { 11. La casa donde viví era muy grande } \\
\text { 12.La casa que yo viví era muy grande. } \\
\text { 13. La casa donde viví era muy grande } \\
\text { 14.La casa más grande de la calle fue la que viví. } \\
\text { 15.La casa en que yo viví era muy grande } \\
\text { 16. La casa en que viví era muy grande. }\end{array}$ \\
\hline $\begin{array}{c}\text { Grupo } \\
\text { C }\end{array}$ & $\begin{array}{l}\text { 17.La casa donde viví era muy grande. } \\
\text { 18.La casa en que yo vivía era muy grande. } \\
\text { 19. La casa en que yo viví queda allí y es muy grande. } \\
\text { 20.La casa que yo viví era muy grande. } \\
\text { 21. La casa en que viví era muy grande. } \\
\text { 22.La casa que allí yo vivía era muy grande. } \\
\text { 23.La casa en que viví era muy grande. }\end{array}$ \\
\hline Grupo & $\begin{array}{l}\text { 24.La casa en que yo viví allí es muy grande. } \\
\text { 25. La casa en la que yo viví, era muy grande. } \\
\text { 26. La casa en la que yo solia vivir era muy grande. } \\
\text { 27. La casa en que yo vivi es muy grande. } \\
\text { 28. La casa en donde yo viví allí es muy grande. } \\
\text { 29. La casa era muy grande, yo viví allí }\end{array}$ \\
\hline
\end{tabular}


Oração G - Hablábamos de una mujer. Esa mujer no era Juana.

\begin{tabular}{|c|c|}
\hline \multicolumn{2}{|r|}{ Oração G - Hablábamos de una mujer. Esa mujer no era Juana. } \\
\hline$\underset{A}{\text { Grupo }}$ & $\begin{array}{l}\text { 1. La mujer que hablábamos no era Juana. } \\
\text { 2. La mujer que hablábamos no era Juana } \\
\text { 3. La mujer que hablábamos no era Juana } \\
\text { 4. La mujer no es Juana. Hablábamos de otra persona. } \\
\text { 5. La mujer que hablábamos no era Juana } \\
\text { 6. La mujer de que hablábamos no era Juana. } \\
\text { 7. La mujer de que hablábamos no era Juana }\end{array}$ \\
\hline $\begin{array}{c}\text { Grupo } \\
\text { B }\end{array}$ & $\begin{array}{l}\text { 8. La mujer de que hablábamos no era Juana. } \\
\text { 9. La mujer de que hablábamos no era Juana } \\
\text { 10.La mujer de quien hablábamos no era Juana. } \\
\text { 11. La mujer sobre quien hablábamos no era Juana. } \\
\text { 12.La mujer de la cual hablábamos no era Juana. } \\
\text { 13.La mujer de que hablábamos no era Juana } \\
\text { 14.La mujer con la que hablamos no era Juana. } \\
\text { 15.La mujer de quien hablábamos no era Juana. } \\
\text { 16. La mujer de la que hablábamos no era Juana. }\end{array}$ \\
\hline $\begin{array}{c}\text { Grupo } \\
\text { C }\end{array}$ & $\begin{array}{l}\text { 17.La mujer de la que hablábamos no era Juana. } \\
\text { 18.La mujer de que hablábamos no era Juana. } \\
\text { 19.La mujer de que hablábamos no era Juana } \\
\text { 20.La mujer de que hablábamos no era Juana } \\
\text { 21.La mujer de la que hablábamos no era Juana } \\
\text { 22.La mujer de que hablábamos no era Juana } \\
\text { 23.La mujer que estábamos hablando no era Juana. }\end{array}$ \\
\hline $\begin{array}{c}\text { Grupo } \\
\text { D }\end{array}$ & $\begin{array}{l}\text { 24.La mujer de que hablamos no era Juana. } \\
\text { 25.La mujer de la que hablábamos, no era Juana. } \\
\text { 26.La mujer de la que hablábamos no era Juana. } \\
\text { 27.La mujer con quien hablamos no era Juana. } \\
\text { 28.La mujer de quien hablamos no era Juana. } \\
\text { 29.La mujer de la que hablamos no era Juana. }\end{array}$ \\
\hline
\end{tabular}


Oração H - La niña usa gafas. A ella le di un helado.

\begin{tabular}{|c|c|}
\hline $\begin{array}{c}\text { Grupo } \\
\text { A }\end{array}$ & $\begin{array}{l}\text { 1. La niña que usa gafas gañó un helado que le di. } \\
\text { 2. La niña que lleva las gafas ganó un helado de mi. } \\
\text { 3. La niña que le di un helado usa gafas. } \\
\text { 4. La niña quedase hermosa con las gafas. } \\
\text { 5. La niña que di un helado usaba gafas. } \\
\text { 6. La niña a quien le di un helado usava gafas. } \\
\text { 7. A la niña que usa gafas le di un helado. }\end{array}$ \\
\hline $\begin{array}{c}\text { Grupo } \\
\text { B }\end{array}$ & $\begin{array}{l}\text { 8. La niña a quien le di un helado usa gafas. } \\
\text { 9. La niña al quien le di un helado usa gafas. } \\
\text { 10. La niña, a quien di un helado, usa gafas. } \\
\text { 11. La niña que usa gafas ganó un helado. } \\
\text { 12. La niña que usa gafas recibió el helado dado por mí. } \\
\text { 13. La niña que usa gafas es guapísima, por eso le di un helado. } \\
\text { 14. La niña que usa gafas le di un helado. } \\
\text { 15. La niña a quien di un helado, usaba gafas. } \\
\text { 16. La niña usa gafas, entonces le di un helado. }\end{array}$ \\
\hline $\begin{array}{c}\text { Grupo } \\
\text { C }\end{array}$ & $\begin{array}{l}\text { 17. La niña a la que le di un helado usa gafas. } \\
\text { 18. A la niña que usa gafas le di un helado. } \\
\text { 19. La niña a la que le di un helado usa gafas. } \\
\text { 20. La niña que usa gafas ganó un helado de mí. } \\
\text { 21. La niña que usa gafas está con un helado regalado por mí. } \\
\text { 22. La niña a la que le di un helado usa gafas. } \\
\text { 23. La niña que usa gafas le di un helado. }\end{array}$ \\
\hline $\begin{array}{c}\text { Grupo } \\
\text { D }\end{array}$ & $\begin{array}{l}\text { 24. La niña que le di un helado usa gafas. } \\
\text { 25. La niña a la que le di un helado, usa gafas. } \\
\text { 26. La niña que usa gafas tomo el helado que le di. } \\
\text { 27. La niña a la que le dia un helado usa gafas. } \\
\text { 28. La niña a quien le di un helado usa gafas. } \\
\text { 29. La niña, a la que le di un helado, usa gafas }\end{array}$ \\
\hline
\end{tabular}




\begin{tabular}{|c|c|}
\hline \multicolumn{2}{|c|}{ Oração I - Con aquella tableta había escrito algunas de mis novelas. Le regalé la tableta a Luís. } \\
\hline$\underset{A}{\text { Grupo }}$ & $\begin{array}{l}\text { 1. Le regalé a Luis aquella tableta que había escrito algunas de mis novelas. } \\
\text { 2. Le regalé a Luis la tableta que yo había escrito algunas de mis novelas. } \\
\text { 3. Le regalé a Luis con la tableta que había escrito algunas novelas. } \\
\text { 4. Le regalé a Luis con todos los cuentos que habían en la tableta. } \\
\text { 5. Le regalé a Luis con la tableta que había escrito algunas de mis novelas. } \\
\text { 6. Le regalé a Luis la tableta que había escrito algunas de mis novelas. } \\
\text { 7. Le regalé a Luis aquella tableta con que yo había escrito algunas de mis novelas. }\end{array}$ \\
\hline $\begin{array}{c}\text { Grupo } \\
\text { B }\end{array}$ & $\begin{array}{l}\text { 8. Le regalé a Luis la tableta con que yo había escrito algunas de mis novelas. } \\
\text { 9. Le regalé a Luis la tableta con que yo había escrito algunas de mis novelas. } \\
\text { 10. Le regalé a Luis la tableta con que yo había escrito algunas de mis novelas. } \\
\text { 11.Le regalé a Luis la tableta con algunas de mis novelas escritas. } \\
\text { 12.Le regalé a Luis la tableta con la cual yo había escrito algunas de mis novelas. } \\
\text { 13. Le regalé a Luis la tableta con que he escrito algunas de mis novelas. } \\
\text { 14.Le regalé a Luis la tableta que había escrito algunas de mis novelas. } \\
\text { 15. Le regalé a Luis aquella tableta en que había escrito algunas de mis novelas. } \\
\text { 16. Le regalé a Luis la tableta que había escrito algunas de mis novelas }\end{array}$ \\
\hline Grupo & $\begin{array}{l}\text { 17.Le regalé a Luis la tableta con la que había escrito algunas de mis novelas. } \\
\text { 18.Le regalé a Luis la tableta con que había escrito algunas de mis novelas. } \\
\text { 19.Le regalé a Luis la tableta en que había escrito algunas de mis novelas. } \\
\text { 20.Le regalé a Luis la tableta que había escrito algunas de mis novelas. } \\
\text { 21.Le regalé a Luis una tableta onde había escrito algunas de mis novelas. } \\
\text { 22.Le regalé a Luis la tableta en que había escrito algunas de mis novelas } \\
\text { 23.Le regalé a Luis aquella tableta con algunas de mis novelas. }\end{array}$ \\
\hline $\begin{array}{c}\text { Grupo } \\
\text { D }\end{array}$ & $\begin{array}{l}\text { 24.Le regalé a Luís la tableta con que escribí algunas de mis novelas. } \\
\text { 25.Le regalé a Luís, la tableta con la que escribí algunas de mis novelas. } \\
\text { 26.Le regalé a Luís la tableta con la que había escrito algunas de mis novelas. } \\
\text { 27.Le regalé a Luís la tableta con la que escribí algunas de mis novelas. } \\
\text { 28.Le regalé a Luís la tableta con la que escribí algunas de mis novelas. } \\
\text { 29.Le regalé a Luís la tableta con la que escribí algunas de mis novelas. }\end{array}$ \\
\hline
\end{tabular}


Oração J - Mi padre me prestó el dinero. Yo no disponía del dinero.

\begin{tabular}{|c|c|c|}
\hline & & Oração J - Mi padre me prestó el dinero. Yo no disponía del dinero. \\
\hline $\begin{array}{c}\text { Grupo } \\
\text { A }\end{array}$ & $\begin{array}{l}1 . \\
2 . \\
3 . \\
4 . \\
5 . \\
6 . \\
7 .\end{array}$ & $\begin{array}{l}\text { Mi padre me he prestado el dinero, pero no me he dispuesto del dinero. } \\
\text { Mi padre me prestó cuando no disponía del diñero. } \\
\text { Mi padre me prestó el dinero que yo precisava. } \\
\text { Mi padre siempre me presta dinero. } \\
\text { Mi padre me prestó el dinero porque no lo disponía yo. } \\
\text { Mi padre me prestó el dinero que yo no disponía. } \\
\text { Mi padre me prestó el dinero porque no lo disponía. }\end{array}$ \\
\hline $\begin{array}{c}\text { Grupo } \\
\text { B }\end{array}$ & $\begin{array}{l}8 . \\
9 . \\
10 . \\
11 . \\
12 . \\
13 . \\
14 . \\
15 . \\
16 .\end{array}$ & $\begin{array}{l}\text { Mi padre me presto el dinero de que yo no disponía. } \\
\text { Mi padre me presto el dinero de que no disponía. } \\
\text { Mi padre me prestó el dinero, ya que no disponía del ello. } \\
\text { Mi padre me prestó el dinero ya que yo no lo disponía. } \\
\text { Mi padre me ayudó prestándome un dinero ya que yo no disponía de nada. } \\
\text { Mi padre me prestó } 10 \text { reales después que supo que yo no disponía del dinero. } \\
\text { Mi padre me prestó el dinero porque yo no disponía. } \\
\text { Mi padre me prestó el dinero porque yo no disponía. } \\
\text { Mi padre me prestó el dinero, pues yo no disponía de el. }\end{array}$ \\
\hline $\begin{array}{c}\text { Grupo } \\
\text { C }\end{array}$ & $\begin{array}{l}17 . \\
18 . \\
19 . \\
20 . \\
21 . \\
22 . \\
23 .\end{array}$ & $\begin{array}{l}\text { Mi padre me prestó el dinero del que yo no disponía. } \\
\text { Mi padre me prestó el dinero de que yo no disponía. } \\
\text { Mi padre me ha prestado el dinero de que yo no disponía. } \\
\text { Mi padre no disponía del dinero que me prestó. } \\
\text { Mi padre me prestó el dinero que yo no disponía. } \\
\text { Mi padre me prestó el dinero de que yo no disponía. } \\
\text { Mi padre me prestó el dinero porque yo no disponía de nada. }\end{array}$ \\
\hline $\begin{array}{c}\text { Grupo } \\
\text { D }\end{array}$ & $\begin{array}{l}24 . \\
25 . \\
26 . \\
27 . \\
28 . \\
29 .\end{array}$ & $\begin{array}{l}\text { Mi padre me presto el dinero porque no disponía de el. } \\
\text { Mi padre me prestó el dinero, del que yo no disponía. } \\
\text { Mi padre me presto el dinero porque yo no tenia. } \\
\text { Mi padre me presto el dinero porque no disponia de el. } \\
\text { Mi padre me presto el dinero ya que no disponia de el. } \\
\text { Mi padre me prestó dinero ya que yo no disponía. }\end{array}$ \\
\hline
\end{tabular}

